PNL-10179

UC-400

\title{
Foreign Energy Company Competitiveness: Background Information
}

\author{
M. R. Weimar \\ K. A. Freund \\ J. M. Roop, Project Manager
}

October 1994

Prepared for

the U.S. Department of Energy

under Contract DE-AC06-76RLO 1830

Pacific Northwest Laboratory

Richland, Washington 99352 
.

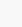




\section{DISCLAIMER}

This report was prepared as an account of work sponsored by an agency of the United States Government. Neither the United States Government nor any agency thereof, nor any of their employees, make any warranty, express or implied, or assumes any legal liability or responsibility for the accuracy, completeness, or usefulness of any information, apparatus, product, or process disclosed, or represents that its use would not infringe privately owned rights. Reference herein to any specific commercial product, process, or service by trade name, trademark, manufacturer, or otherwise does not necessarily constitute or imply its endorsement, recommendation, or favoring by the United States Government or any agency thereof. The views and opinions of authors expressed herein do not necessarily state or reflect those of the United States Government or any agency thereof. 


\section{DISCLAIMER}

\section{Portions of this document may be illegible in electronic image products. Images are produced from the best available original document.}




\section{Executive Summary}

This report provides background information to the report Energy Company Competitiveness: Little to Do With Subsidies (DOE 1994). The main body of this publication consists of data uncovered during the course of research on this DOE report. This data pertains to major government energy policies in each country studied. This report also provides a summary of the DOE report.

In October 1993, the Office of Energy Intelligence, U.S. Department of Energy (formerly the Office of Foreign Intelligence), requested that Pacific Northwest Laboratory prepare a report addressing policies and actions used by foreign governments to enhance the competitiveness of their energy firms. Pacific Northwest Laboratory prepared the report Energy Company Competitiveness Little to Do With Subsidies (DOE 1994), which provided the analysis requested by DOE. An appendix was also prepared, which provided extensive background documentation to the analysis. Because of the length of the appendix, Pacific Northwest Laboratory decided to publish this information separately, as contained in this report.

In the conduct of research for the DOE report, countries were examined that are home to the world's largest oil and gas companies and, to a lesser extent, coal companies. The countries examined in the greatest detail were the United States, Australia, Canada, France, Mexico, the Netherlands, Norway, and the United Kingdom. The policies of Japan and Germany were also studied as they relate to their oil and coal industries.

The research primarily focused on

- direct subsidies to industry, such as direct payments and below-market-cost loans

- indirect subsidies to industry, such as government-sponsored research and development

- preferential treatment to domestic companies for development of resources, investment, or any other purposes

- taxation, such as tax holidays

- environmental regulations and enforcement of environmental laws

- laws affecting the conduct of business in overseas markets

- nontariff barriers

- direct government involvement in the industry, through ownership or other means that could affect competitiveness. 


\section{Findings of Energy Company Competitiveness: Little To Do With Subsidies (DOE 1994)}

Traditionally, foreign governments have been actively involved in their energy companies through full or partial ownership, subsidies, and exclusive production arrangements. Recently, however, governments are liberalizing their energy regimes to attract foreign capital and increase productive capacity. As a result; direct government involvement is decreasing as governments privatize major oil and gas firms, provide less direct subsidization, and give less preferential treatment to their domestic firms. Nevertheless, foreign governments continue to play a very important, indirect role in providing their energy firms with a competitive edge. Among the findings of the DOE study are the following:

- Lower environmental costs in foreign countries provide an important competitive edge to foreign energy companies in their domestic markets. The National Petroleum Council estimates Canada's and Northwest Europe's levels of environmental regulations at only $75 \%$ of the U.S. level.

- Different foreign business standards from those adopted by the United States sometimes place foreign energy companies at an advantage over U.S. companies in global markets. Many foreign governments continue to allow their companies to conduct business with countries that the United States identifies as supporting terrorism or committing acts of war. In addition, other countries permit practices that the United States proscribes as corrupt and prohibits under the Foreign Corrupt Practices Act (FCPA).

- There are a number of foreign countries where privatization in the energy sector is not complete and there remains continuing preferential treatment and subsidies. The potential effect on U.S. companies is not as great as might be suggested, however, because some countries, such . as Japan and Canada, provide a share of the equity capital for the oil and gas consortia in which U.S. companies are involved.

- Most of the countries studied, including France, the Netherlands, and the United Kingdom, still have government-owned companies in certain sectors, particularly coal, that usually make the sector a de facto monopoly, which prevents competition from domestic and foreign firms and reduces potential foreign market share. Subsidies to foreign coal companies in Canada, France, Germany, Japan, Norway, and the United Kingdom potentially reduce U.S. and Australian coal exports. Lower Australia and Canadian regulatory costs, along with lower rail transportation costs, reduce U.S. coal industry competitiveness. 


\section{Abbreviations/Acronyms}

$\begin{array}{ll}\text { Ademe } & \text { Agence de l'Environment et de la Maitrise de l'Energie } \\ \text { ANWR } & \text { Artic National Wildlife Refuge } \\ \text { API } & \text { American Petroleum Institute } \\ \text { bb } & \text { billion barrels } \\ \text { bcf } & \text { billion cubic feet } \\ \text { bcfd } & \text { billion cubic feet per day } \\ \text { bd } & \text { barrels per day } \\ \text { CDE } & \text { Comision Federal de Electricidad } \\ \text { CdF } & \text { Charbonages de France } \\ \text { CEA } & \text { Commissariat al l'Energie Atomique } \\ \text { CFTA } & \text { U.S.-Canada Free Trade Agreement } \\ \text { E\&P } & \text { exploration and production } \\ \text { EBN } & \text { Energie Beheer Nederland } \\ \text { EC } & \text { European Community } \\ \text { ECN } & \text { The Netherlands Energy Research Foundation } \\ \text { EDF } & \text { Electricite de France } \\ \text { Elf } & \text { Elf-Aquitaine } \\ \text { EPA } & \text { Environmental Protection Agency } \\ \text { EPACT } & \text { Energy Policy Act } \\ \text { EXIM } & \text { Export-Import } \\ \text { FCPA } & \text { Foreign Corrupt Practices Act } \\ \text { FERC } & \text { Federal Energy Regulatory Commission } \\ \text { FY } & \text { fiscal year } \\ \text { GATT } & \text { General Agreement on Tariffs and Trade } \\ \text { GdF } & \text { Gaz de France } \\ \text { GFU } & \text { Norwegian Gas Negotiating Consortium } \\ \text { GNP } & \text { gross national product } \\ \text { GWh } & \text { gigawatt hours } \\ \text { IEA } & \text { International Energy Agency } \\ \text { LNG } & \text { liquified natural gas } \\ \text { LPG } & \text { liquid propane gas } \\ \text { mbd } & \text { million barrels per day } \\ \text { mcfd } & \text { million cubic feet per day } \\ \text { MTOE } & \text { million metric tons oil equivalent } \\ \text { MW } & \text { megawatt } \\ \text { NAFTA } & \text { North American Free Trade Agreement } \\ \text { NEPP } & \text { National Environment Policy Plan } \\ \text { NES } & \text { National Energy Strategy } \\ \text { NOVEM } & \text { The Netherlands Agency for Energy and the Environment } \\ \text { NRC } & \text { Nuclear Regulatory Commission } \\ & \end{array}$


OCS outer continental shelf

OECD Organization for Economic Cooperation and Development

PEMEX Petroleos Mexicanos

PERD Panel on Energy Research and Development

PES Public Electric Supply

PRT Petroleum Revenue Tax

PUHCA Public Utility Holding Company Act

R\&D research and development

REC regional electric company

RRT Resource Rent Tax

SEP Dutch Cooperative Public Electricity Production Companies

st short ton

TFC total final consumption

TPES total primary energy supply

TST Goods and Services Tax

U.K. United Kingdom

VAT value added tax 


\section{Acknowledgments}

The authors relied heavily on telephone contacts in the course of our research. We wish to acknowledge and thank those contacts, all of whom are listed in the back of the report. Advice and comments from Michael G. Ortmeier greatly improved this work and are greatly appreciated. We also wish to acknowledge Brian Shaw, who provided valuable insight and guidance. Appreciation is also

due to Orman Paananen for his painstaking review of this document. Finally, the authors acknowledge the significant contribution of our editors, Robert Buchanan and Marye Hefty. 



\section{Contents}

Executive Summary $\ldots \ldots \ldots \ldots \ldots \ldots \ldots \ldots \ldots \ldots \ldots \ldots \ldots \ldots$ iii

Abbreviations/Acronyms $\ldots \ldots \ldots \ldots \ldots \ldots \ldots \ldots \ldots \ldots \ldots \ldots$

Acknowledgments $\ldots \ldots \ldots \ldots \ldots \ldots \ldots \ldots \ldots \ldots \ldots \ldots \ldots \ldots$ vii

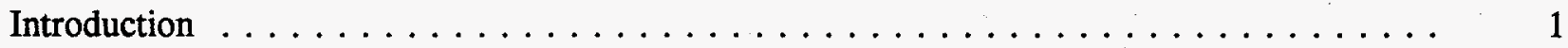

Summary of Energy Company Competitiveness: Little To

Do With Subsidies (DOE 1994) ${ }^{\prime} \ldots \ldots \ldots \ldots \ldots \ldots \ldots \ldots \ldots$

Foreign Environmental and Business Regulations Provide Cost Advantage . . . . . . 3

Foreign Government Involvement $\ldots \ldots \ldots \ldots \ldots \ldots \ldots \ldots \ldots \ldots$

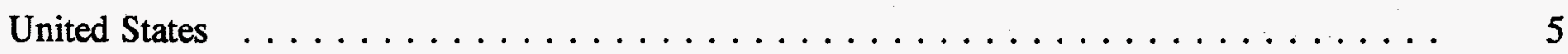

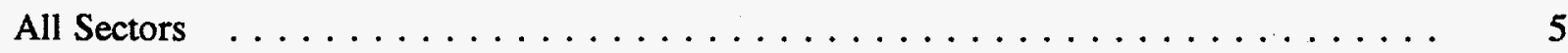

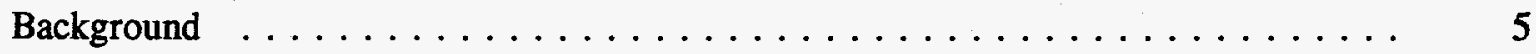

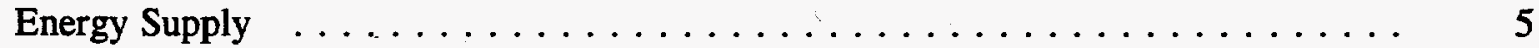

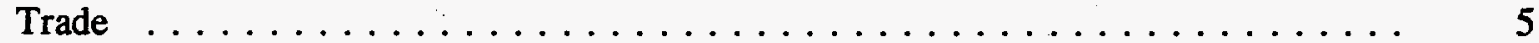

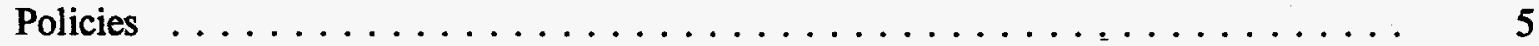

Government Ownership of Business Entities $\ldots \ldots \ldots \ldots \ldots \ldots \ldots \ldots \ldots \ldots$

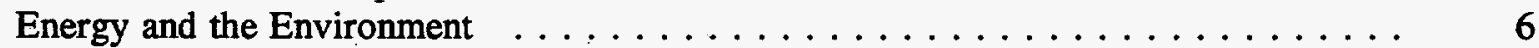

Subsidies $\ldots \ldots \ldots \ldots \ldots \ldots \ldots \ldots \ldots \ldots \ldots \ldots \ldots \ldots \ldots$

Government-Sponsored Research and Development $\ldots \ldots \ldots \ldots \ldots$

Taxes $\ldots \ldots \ldots \ldots \ldots \ldots \ldots \ldots \ldots \ldots \ldots \ldots \ldots \ldots \ldots$

Crude Oil $\ldots \ldots \ldots \ldots \ldots \ldots \ldots \ldots \ldots \ldots \ldots \ldots \ldots \ldots \ldots \ldots \ldots$

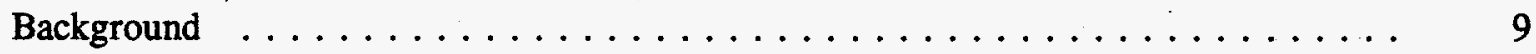

Government Ownership of Business Entities $\ldots \ldots \ldots \ldots \ldots \ldots \ldots \ldots \ldots$

Government Ownership of Natural Resources $\ldots \ldots \ldots \ldots \ldots \ldots$

Investment and Production Restrictions $\ldots \ldots \ldots \ldots \ldots \ldots \ldots \ldots \ldots$

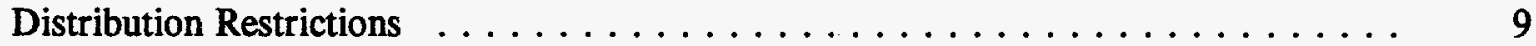

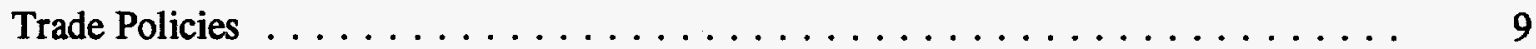

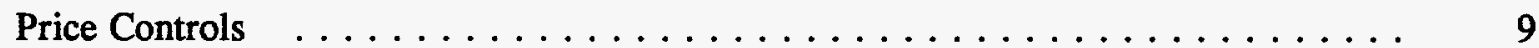

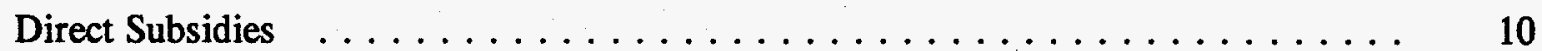

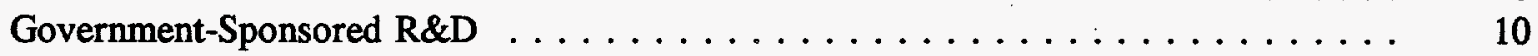

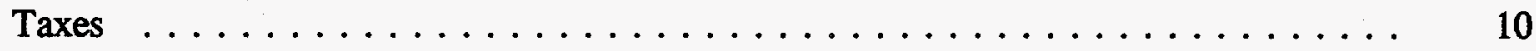


Refined Oil

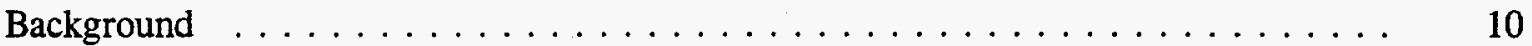

Government Ownership of Business Entities $\ldots \ldots \ldots \ldots \ldots \ldots$

Investment and Production Restrictions $\ldots \ldots \ldots \ldots \ldots \ldots \ldots$

Distribution Restrictions . . . . . . . . . . . . . . . . . . . . . . 10

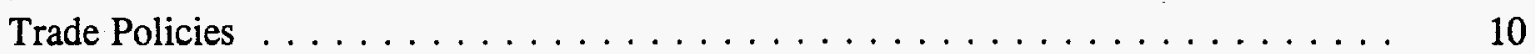

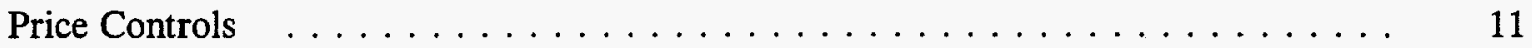

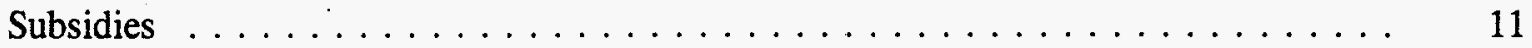

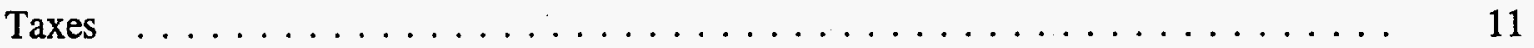

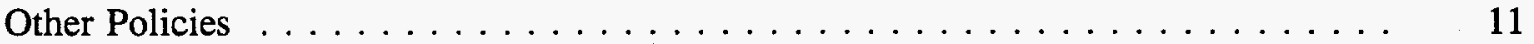

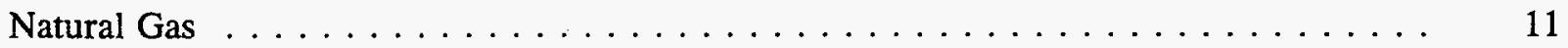

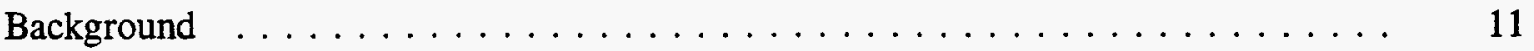

Government Ownership of Business Entities $\ldots \ldots \ldots \ldots \ldots \ldots \ldots$

Government Ownership of Natural Resources $\ldots \ldots \ldots \ldots \ldots \ldots \ldots$

Investment and Production Restrictions $\ldots \ldots \ldots \ldots \ldots \ldots \ldots \ldots \ldots \ldots$

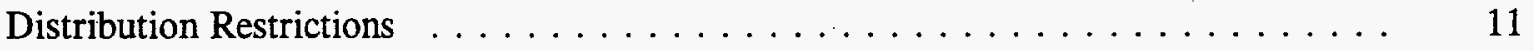

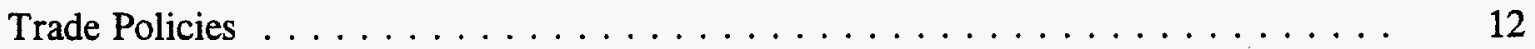

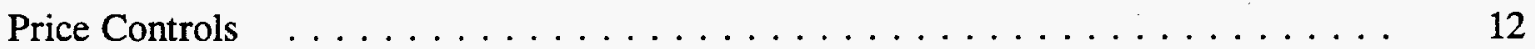

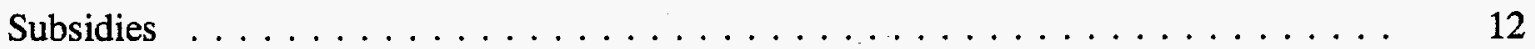

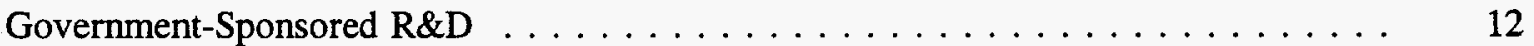

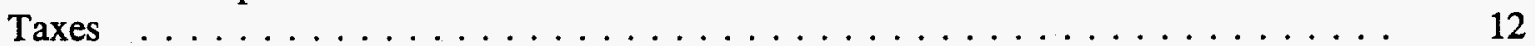

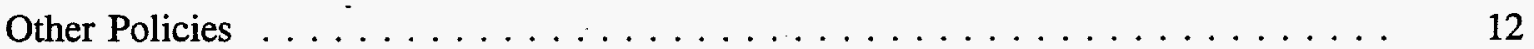

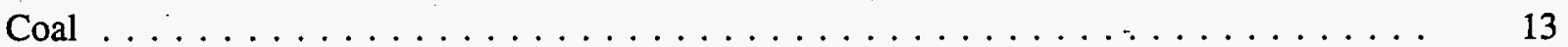

Government Ownership of Business Entities $\ldots \ldots \ldots \ldots \ldots \ldots$

Government Ownership of Natural Resources $\ldots \ldots \ldots \ldots \ldots \ldots$

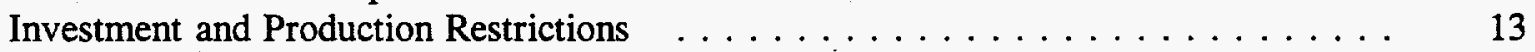

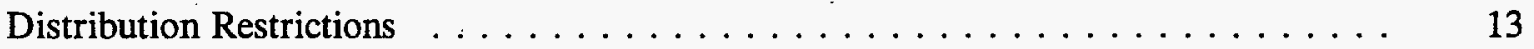

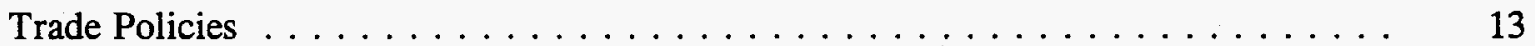

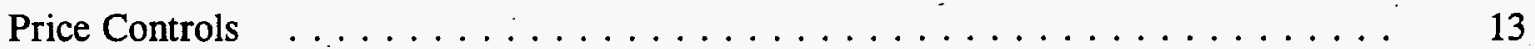

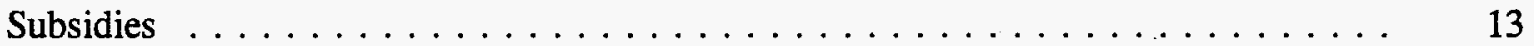

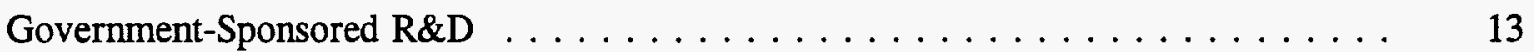

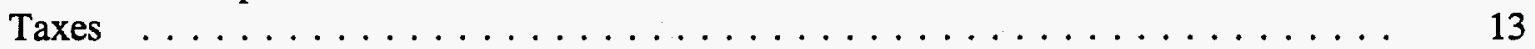

Other Policies $\ldots \ldots \ldots \ldots \ldots \ldots \ldots \ldots \ldots \ldots \ldots \ldots \ldots$

Nuclear $\ldots \ldots \ldots \ldots \ldots \ldots \ldots \ldots \ldots \ldots \ldots \ldots \ldots \ldots$

Background . . . . . . . . . . . . . . . . . . . . . . 14

Government Ownership of Business Entities $\ldots \ldots \ldots \ldots \ldots \ldots \ldots \ldots$

Government Ownership of Natural Resources $\ldots \ldots \ldots \ldots \ldots \ldots \ldots$

Production Restrictions . . . . . . . . . . . . . . . . . . . . . . 14

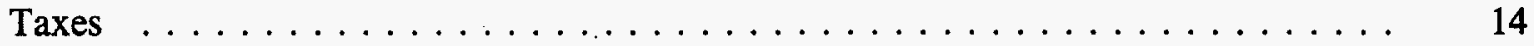

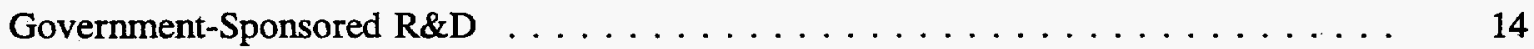




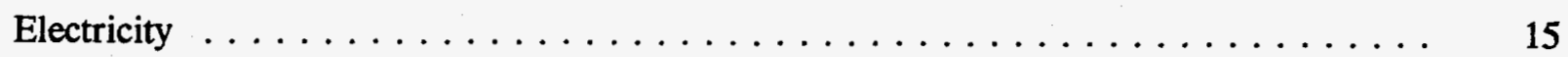

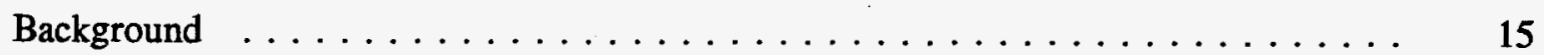

Government Ownership of Business Entities $\ldots \ldots \ldots \ldots \ldots \ldots \ldots$

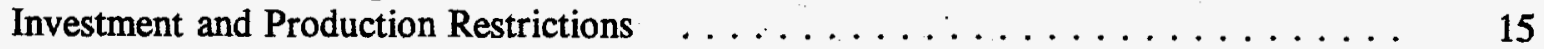

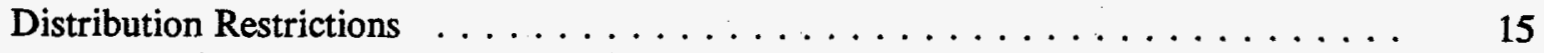

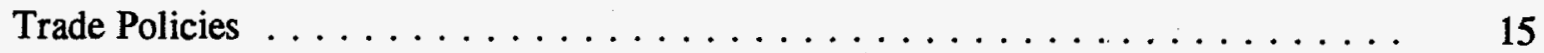

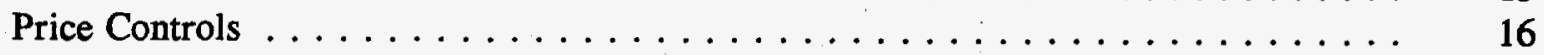

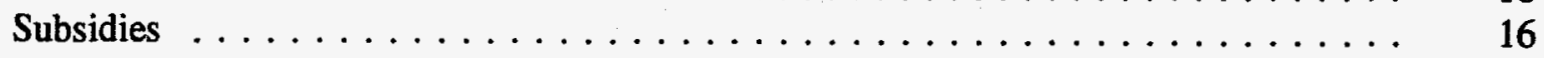

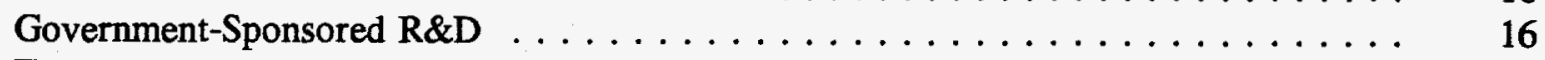

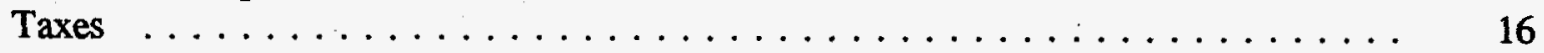

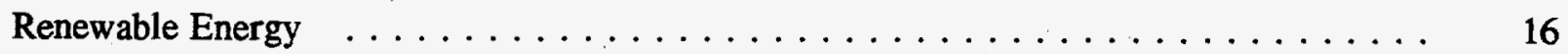

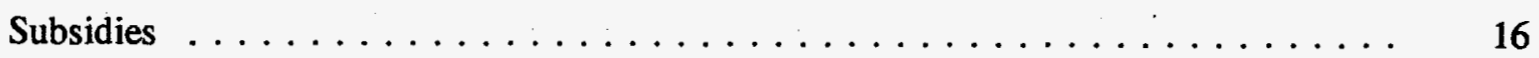

Government-Sponsored R\&D . . . . . . . . . . . . . . . . 16

Australia $\ldots \ldots \ldots \ldots \ldots \ldots \ldots \ldots \ldots \ldots \ldots \ldots \ldots \ldots \ldots \ldots$

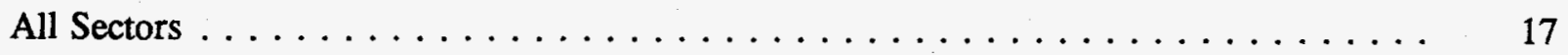

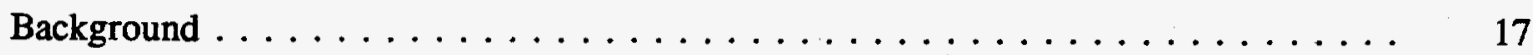

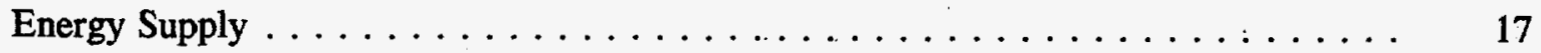

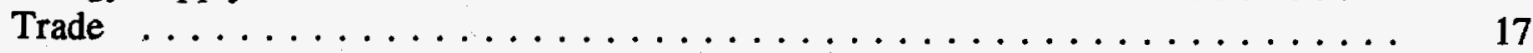

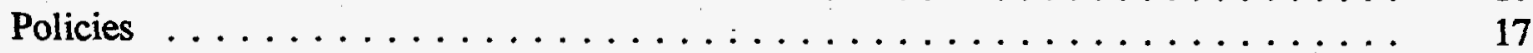

Energy and the Environment $\ldots \ldots \ldots \ldots \ldots \ldots \ldots \ldots \ldots \ldots \ldots$

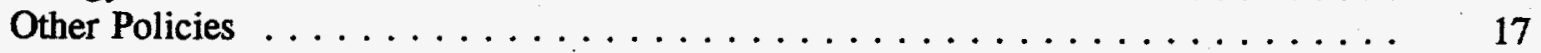

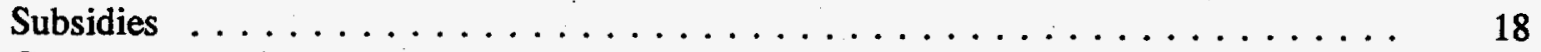

Government-Sponsored $\mathrm{R} \& \mathrm{D} \ldots \ldots \ldots \ldots \ldots \ldots \ldots \ldots \ldots$

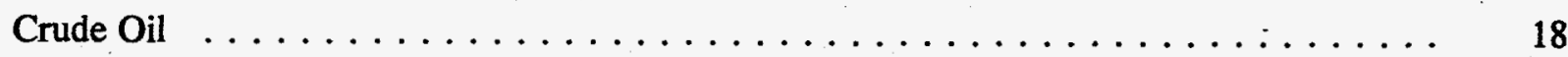

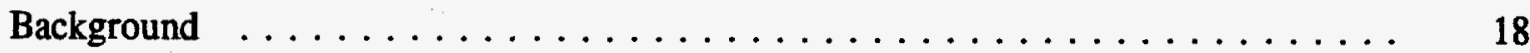

Government Ownership of Business Entities $\ldots \ldots \ldots \ldots \ldots \ldots \ldots \ldots \ldots$

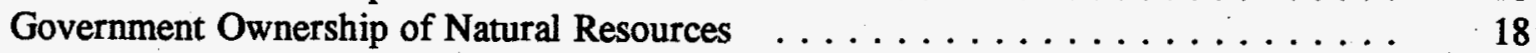

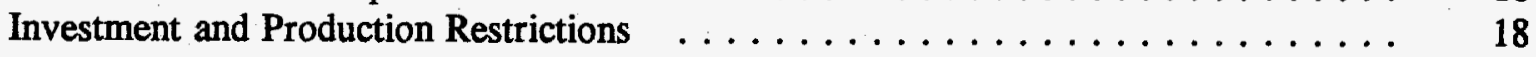

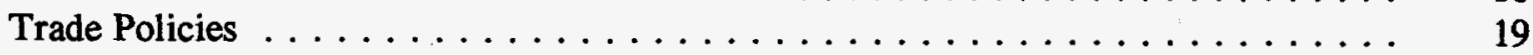

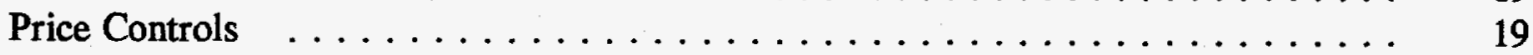

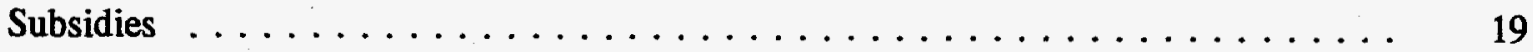

Government-Sponsored R\&D . . . . . . . . . . . . . . . . . . 19

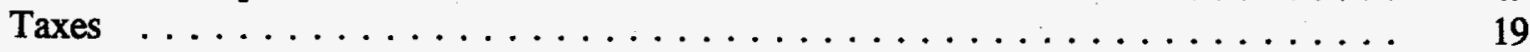

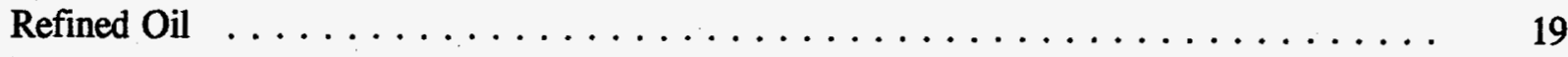

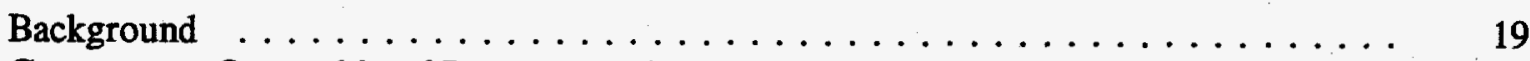

Government Ownership of Business Entities $\ldots \ldots \ldots \ldots \ldots \ldots \ldots$

Trade Policies . . . . . . . . . . . . . . . . . . . . . . . . . . 19

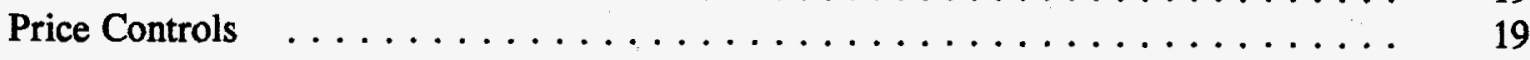




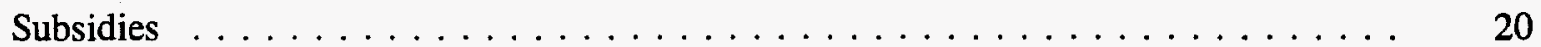

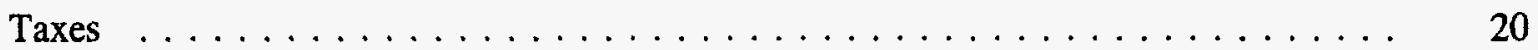

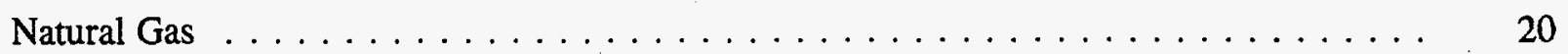

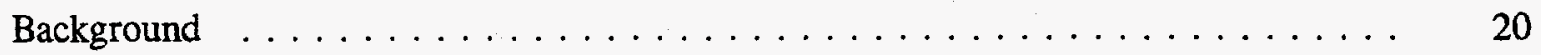

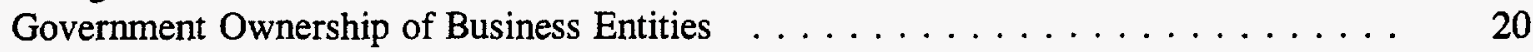

Government Ownership of Natural Resources . . . . . . . . . . . . . . 20

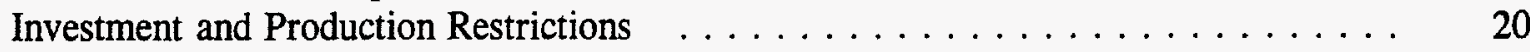

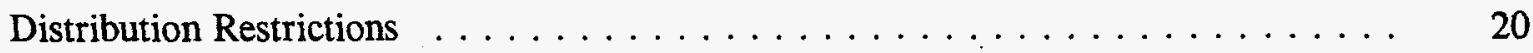

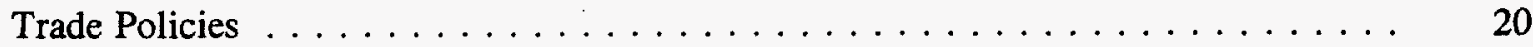

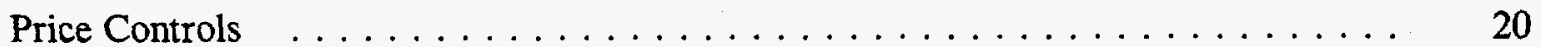

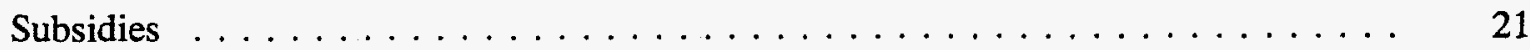

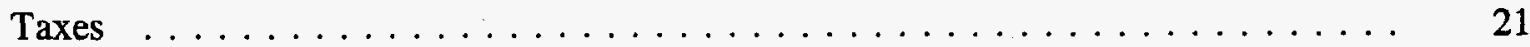

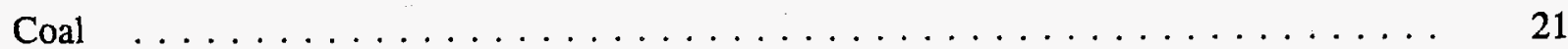

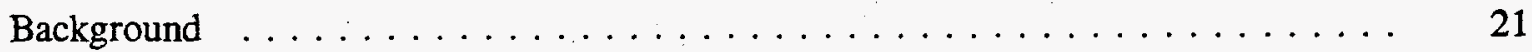

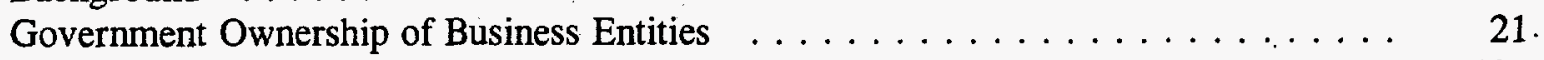

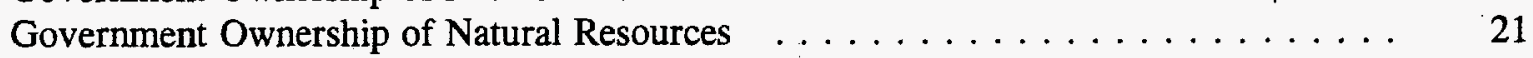

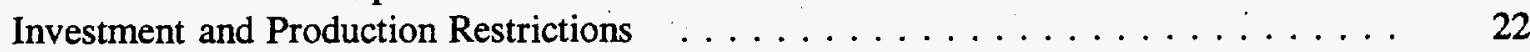

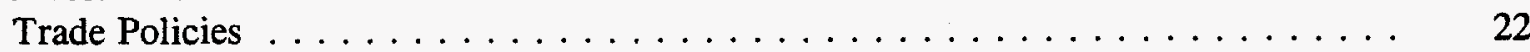

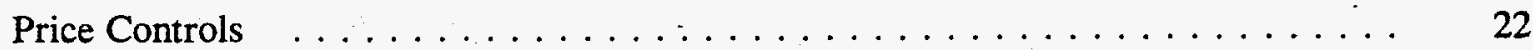

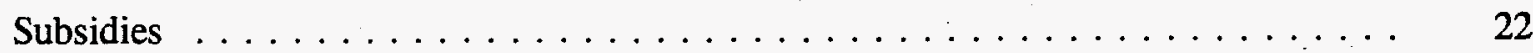

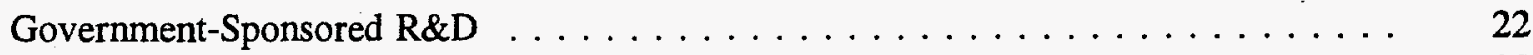

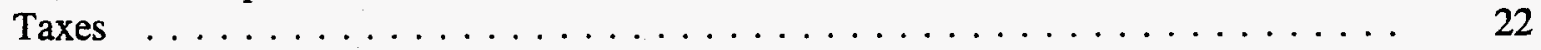

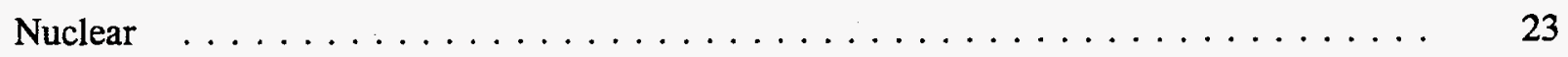

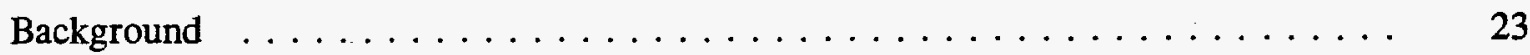

Government Ownership of Natural Resources $\ldots \ldots \ldots \ldots \ldots \ldots \ldots \ldots$

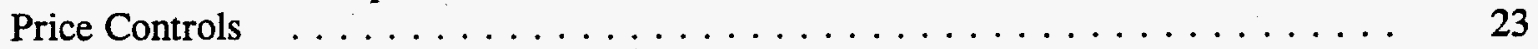

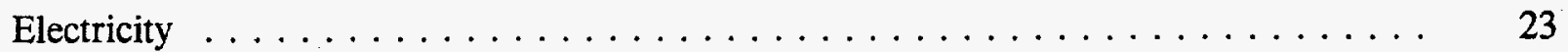

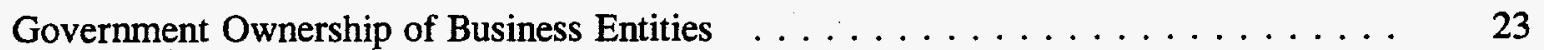

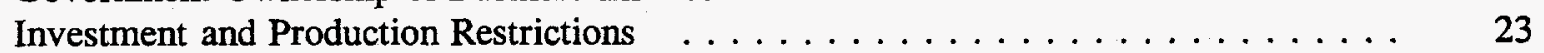

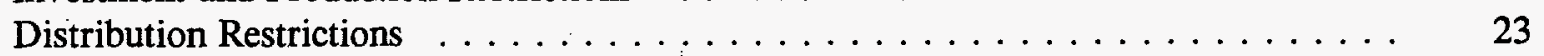

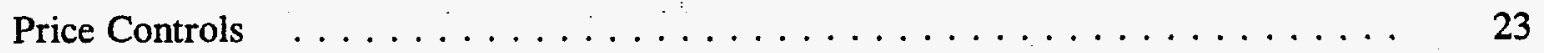

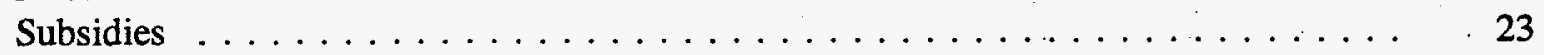

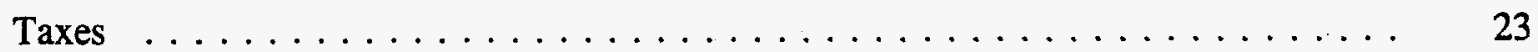

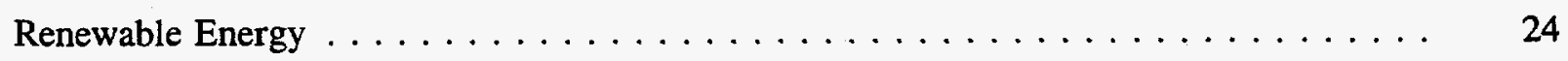

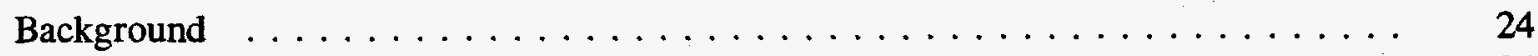

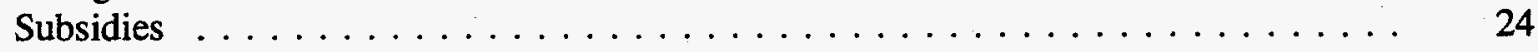

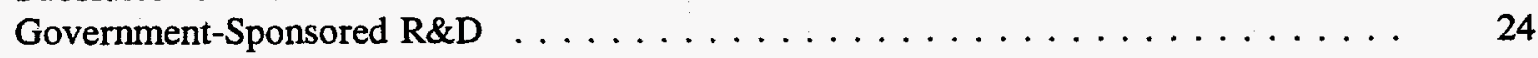


Canada $\ldots \ldots \ldots \ldots \ldots \ldots \ldots \ldots \ldots \ldots \ldots \ldots \ldots \ldots \ldots \ldots \ldots \ldots$

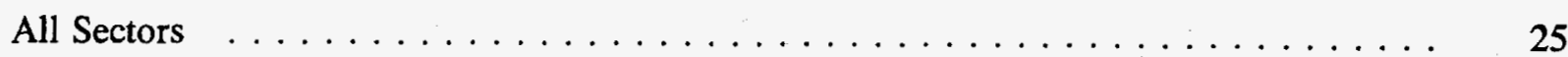

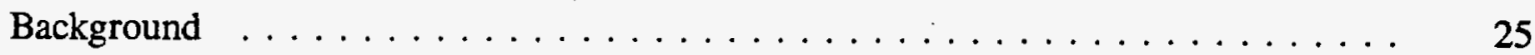

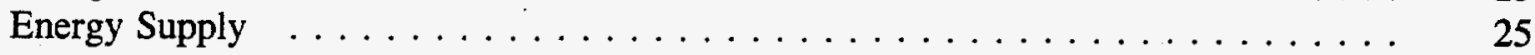

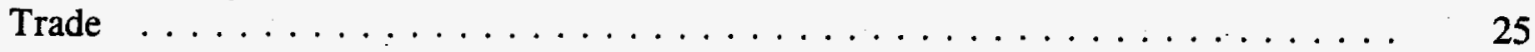

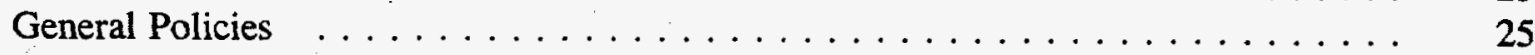

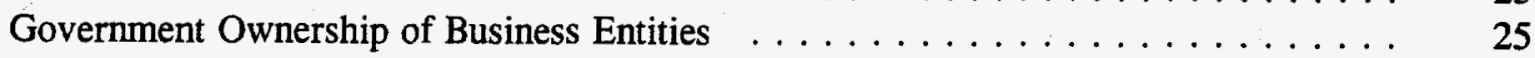

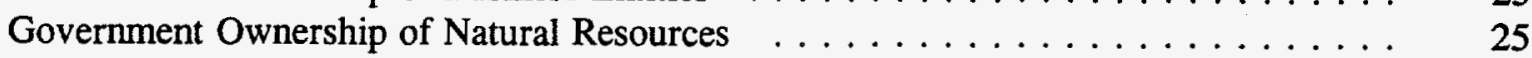

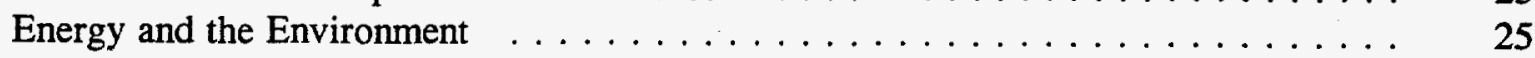

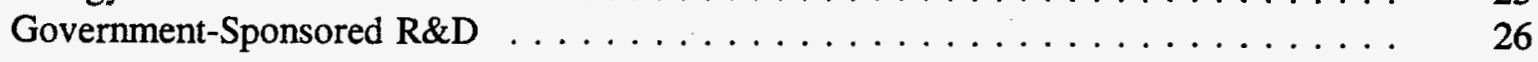

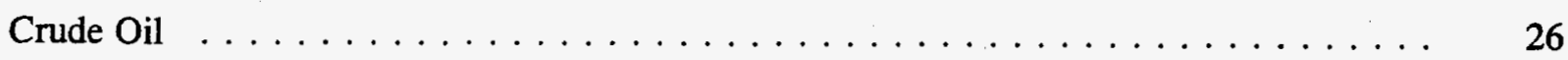

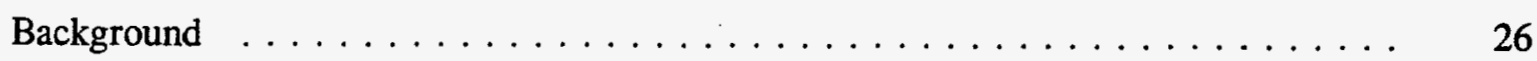

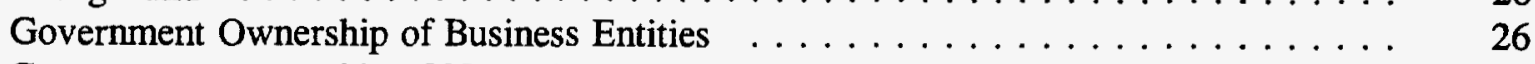

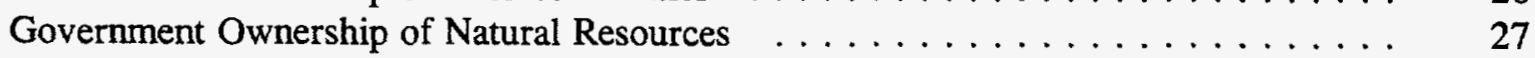

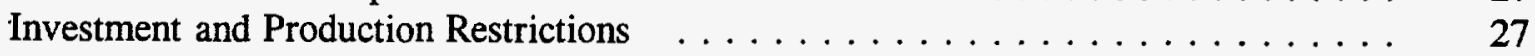

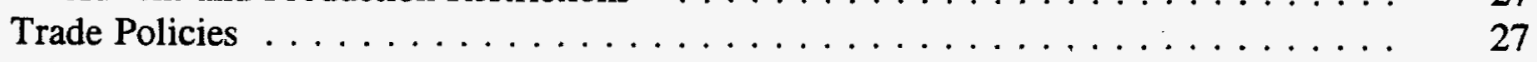

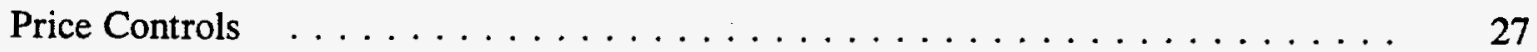

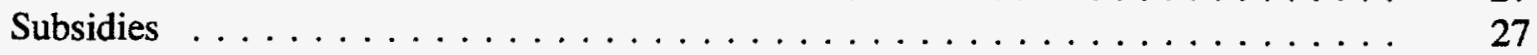

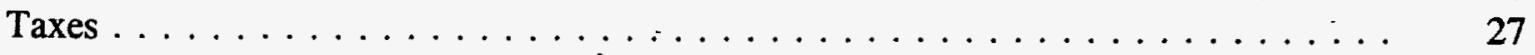

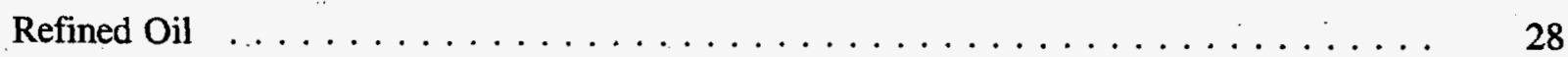

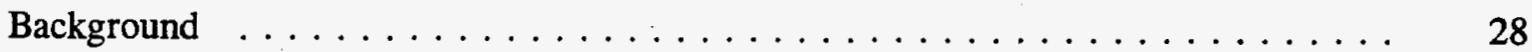

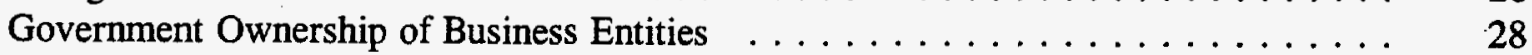

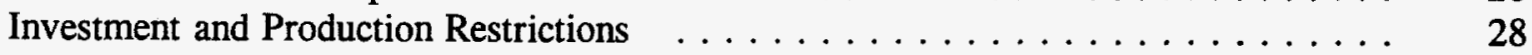

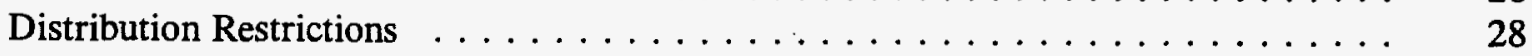

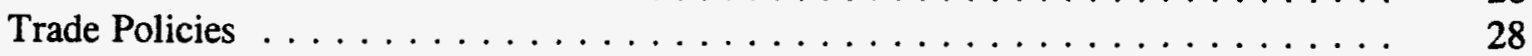

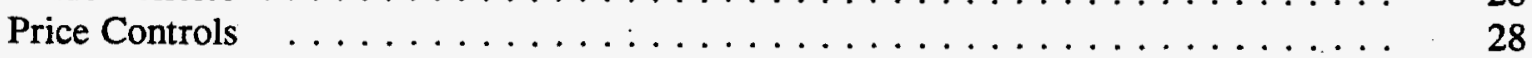

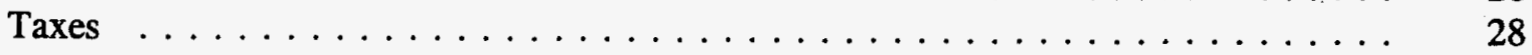

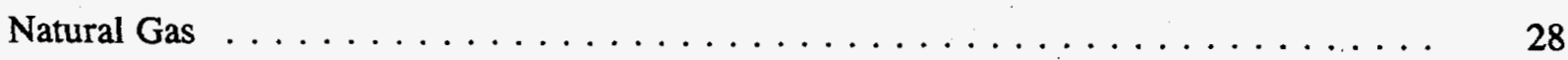

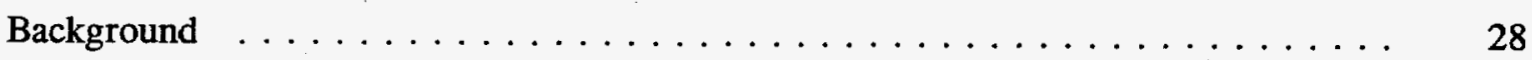

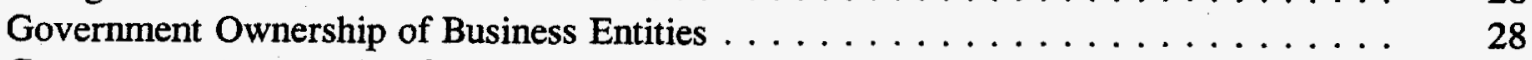

Government Ownership of Natural Resources . . . . . . . . . . . . . 28

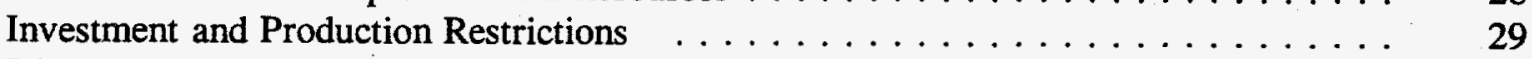

Distribution Restrictions . . . . . . . . . . . . . . . . . . . 29

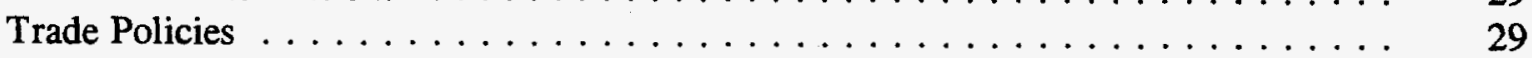

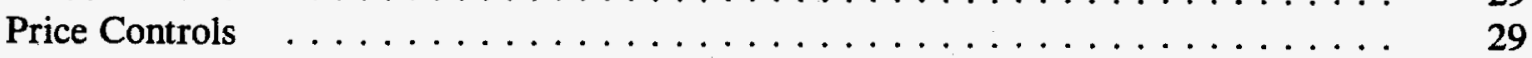

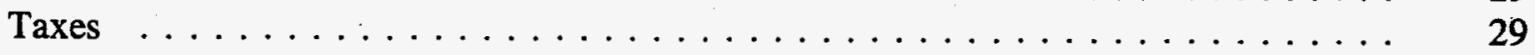


Coal

Background . . . . . . . . . . . . . . . . . . . . . 29

Government Ownership of Business Entities . . . . . . . . . . . . . . . . 29

Government Ownership of Natural Resources $\ldots \ldots \ldots \ldots \ldots \ldots \ldots$

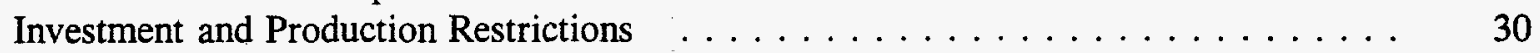

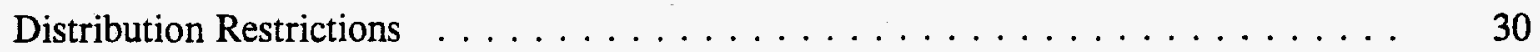

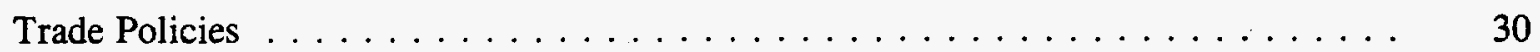

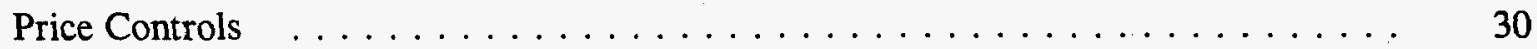

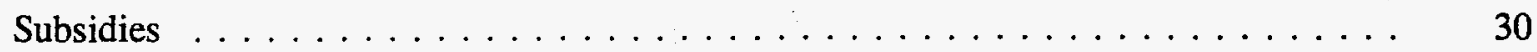

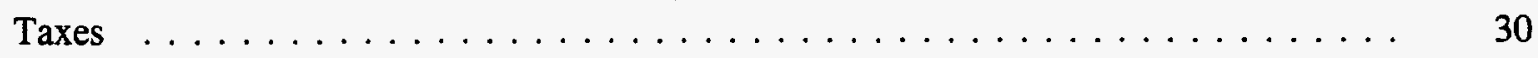

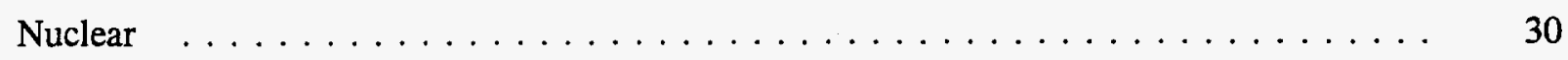

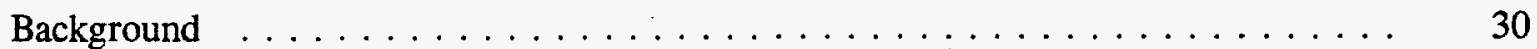

Government Ownership of Business Entities . . . . . . . . . . . . . 30

Government Ownership of Natural Resources . . . . . . . . . . . . . . 30

Investment and Production Restrictions $\ldots \ldots \ldots \ldots \ldots \ldots \ldots \ldots$

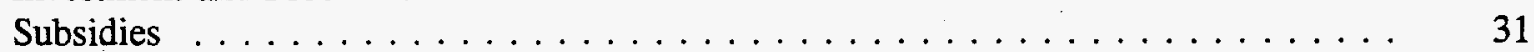

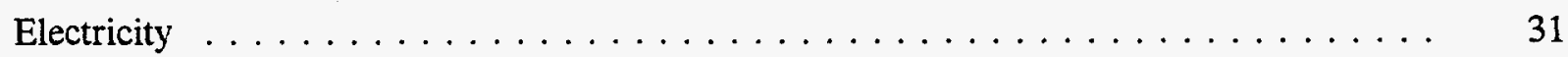

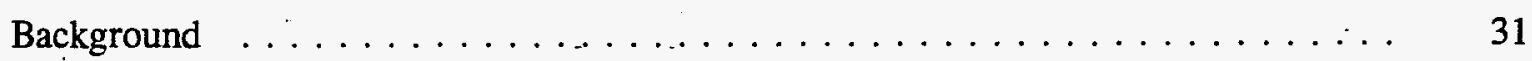

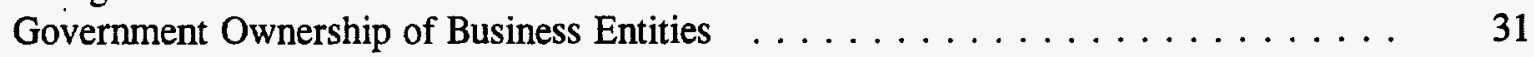

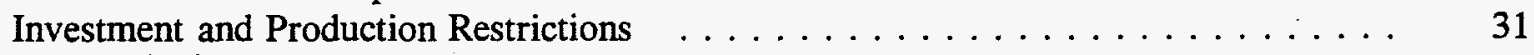

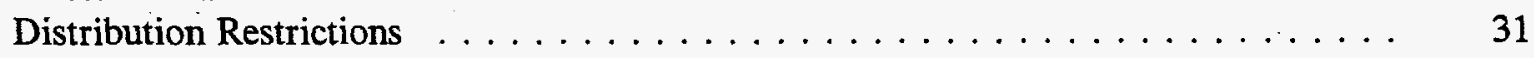

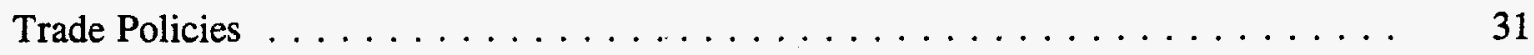

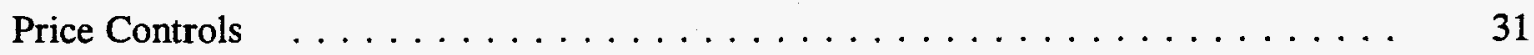

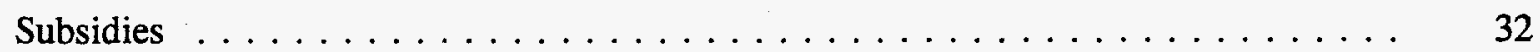

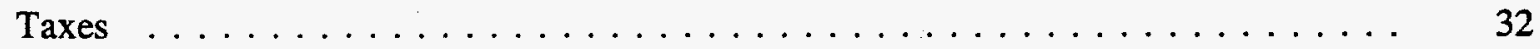

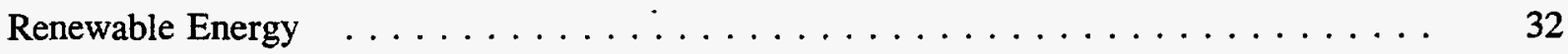

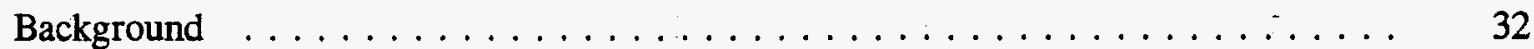

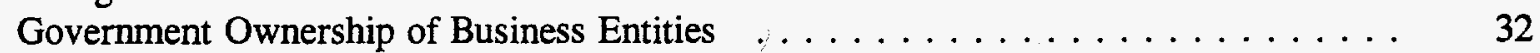

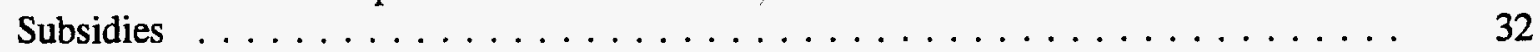

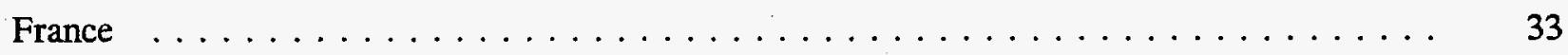

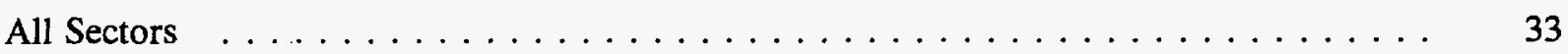

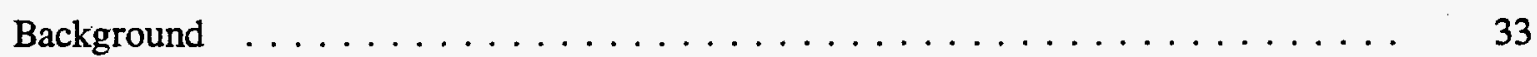

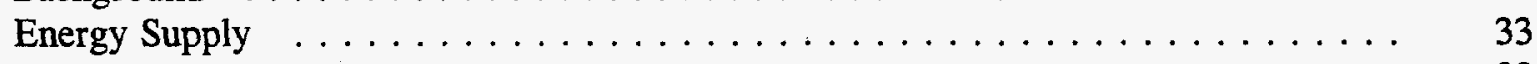

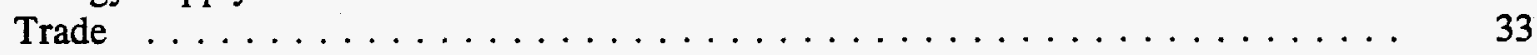

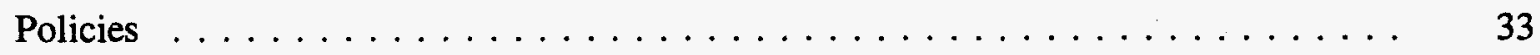

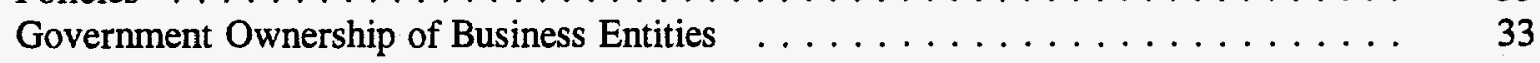

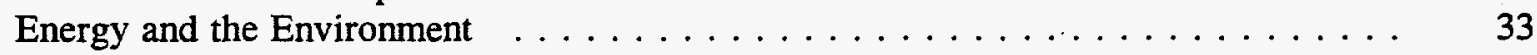

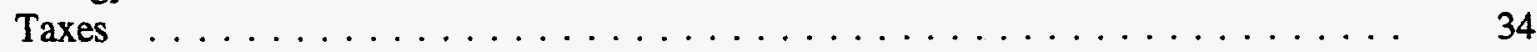


Government-Sponsored $R \& D \quad \ldots \ldots \ldots \ldots \ldots \ldots \ldots \ldots \ldots \ldots$

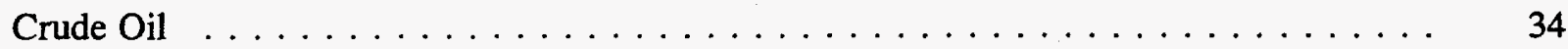

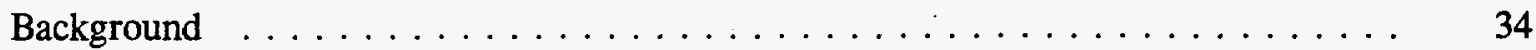

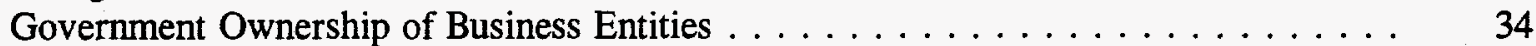

Government Ownership of Natural Resources $\ldots \ldots \ldots \ldots \ldots \ldots \ldots$

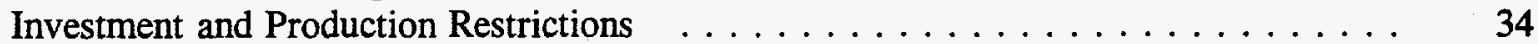

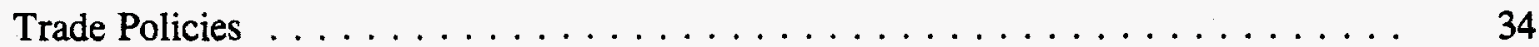

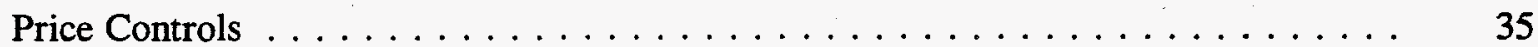

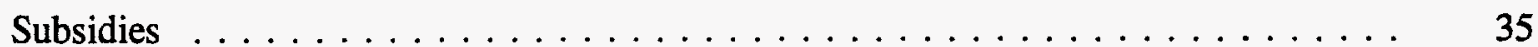

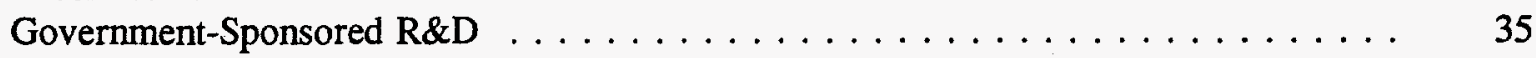

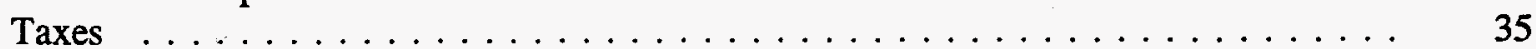

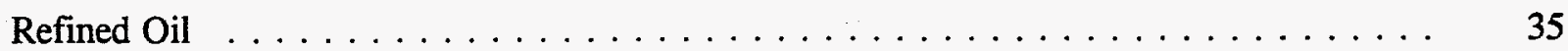

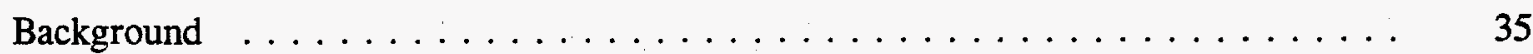

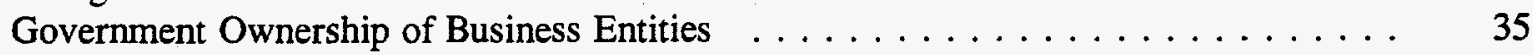

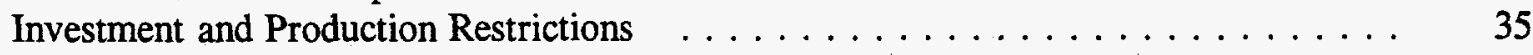

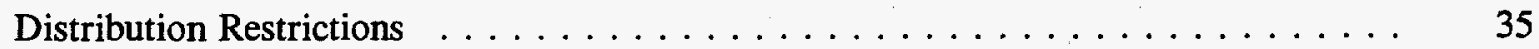

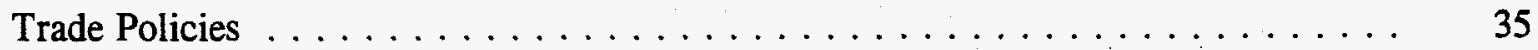

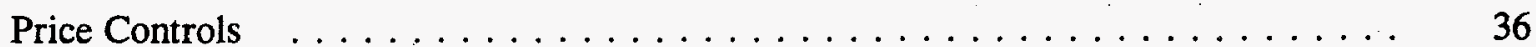

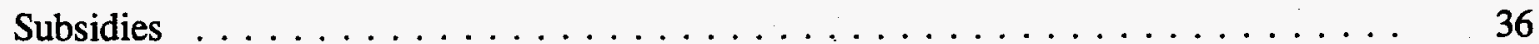

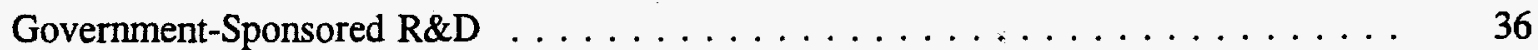

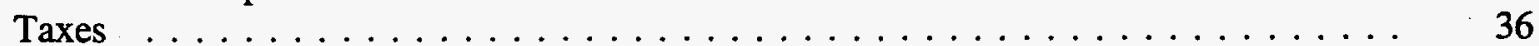

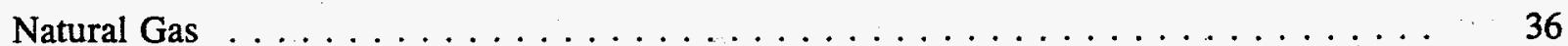

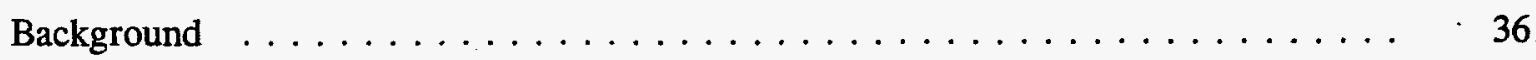

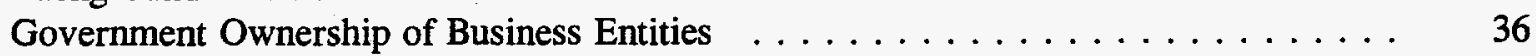

Government Ownership of Natural Resources $\ldots \ldots \ldots \ldots \ldots \ldots \ldots \ldots$

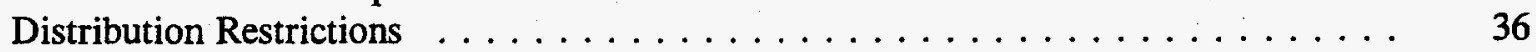

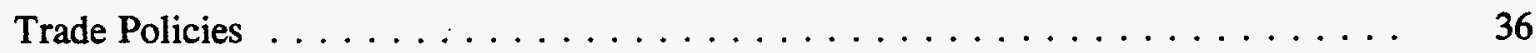

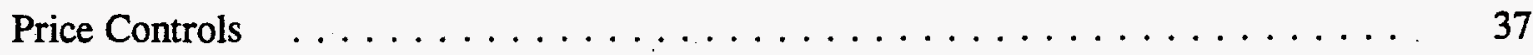

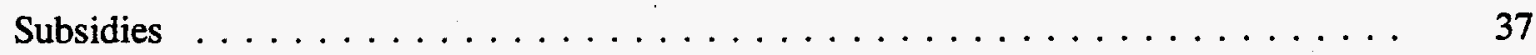

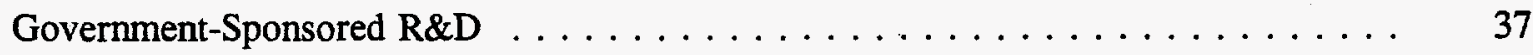

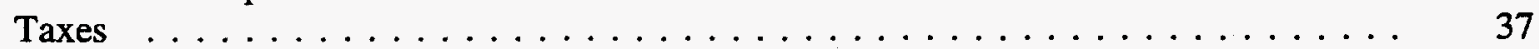

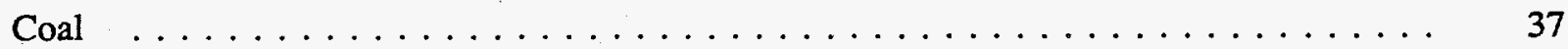

Government Ownership of Business Entities $\ldots \ldots \ldots \ldots \ldots \ldots \ldots \ldots$

Government Ownership of Natural Resources . . . . . . . . . . . . . . 37

Investment and Production Restrictions $\ldots \ldots \ldots \ldots \ldots \ldots \ldots \ldots \ldots \ldots$

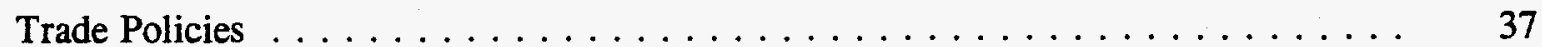

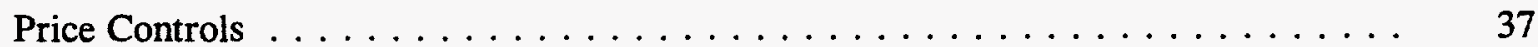

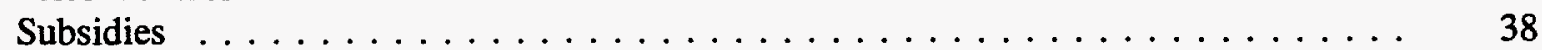

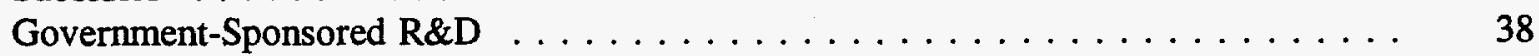

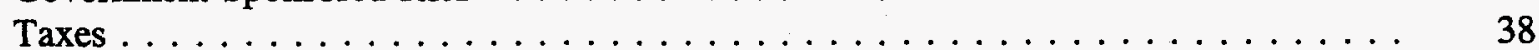




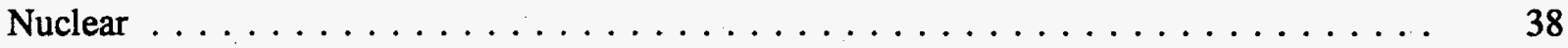

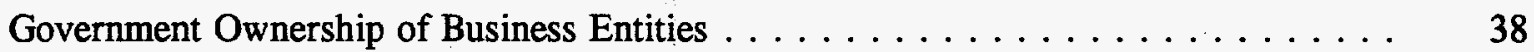

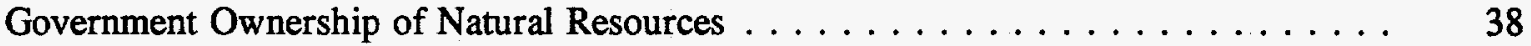

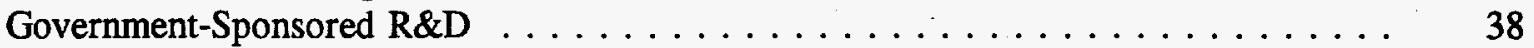

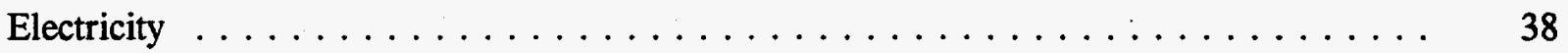

Background . . . . . . . . . . . . . . . . . . . . . . 38

Government Ownership of Business Entities . . . . . . . . . . . . . 39

Investment and Production Restrictions . . . . . . . . . . . . . . . 39

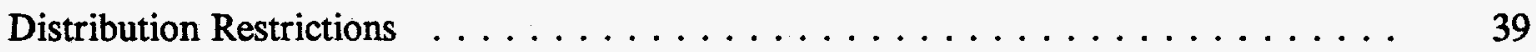

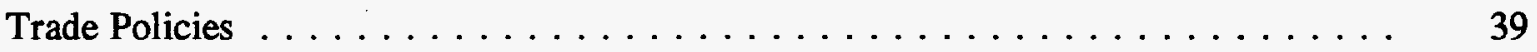

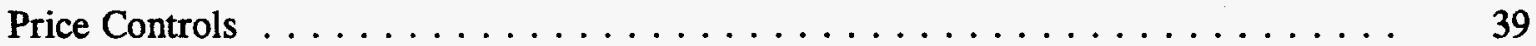

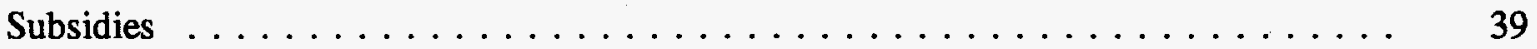

Government-Sponsored R\&D . . . . . . . . . . . . . . . . . 39

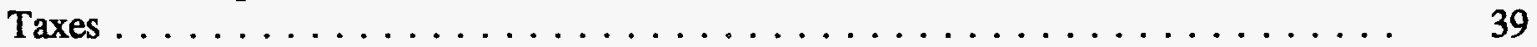

Renewable Energy . . . . . . . . . . . . . . . . . . . . . . . . 39

Government Ownership of Business Entities $\ldots \ldots \ldots \ldots \ldots \ldots$

Investment and Production Restrictions . . . . . . . . . . . . . 39

Government-Sponsored R\&D . . . . . . . . . . . . . . . . . 40

Mexico $\ldots \ldots \ldots \ldots \ldots \ldots \ldots \ldots \ldots \ldots \ldots \ldots \ldots \ldots \ldots \ldots \ldots \ldots \ldots$

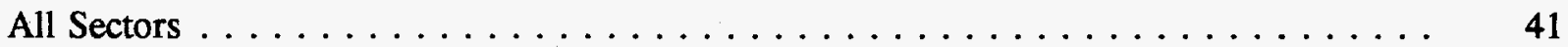

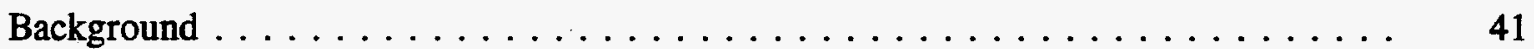

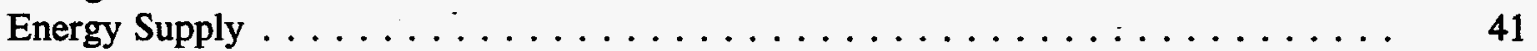

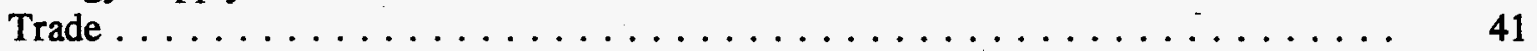

Policies . . . . . . . . . . . . . . . . . . . . . . 41

Government Ownership of Business Entities . . . . . . . . . . . . . 41

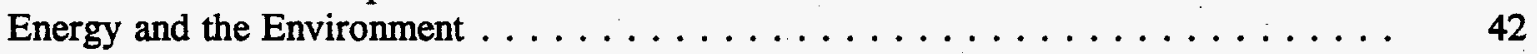

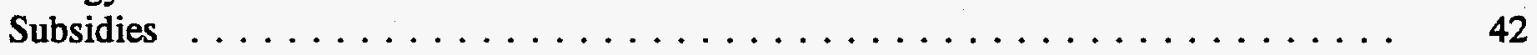

Government-Sponsored R\&D . . . . . . . . . . . . . . . 42

Crude Oil $\ldots \ldots \ldots \ldots \ldots \ldots \ldots \ldots \ldots \ldots \ldots \ldots \ldots \ldots \ldots \ldots \ldots \ldots$

Background . . . . . . . . . . . . . . . . . . . . 42

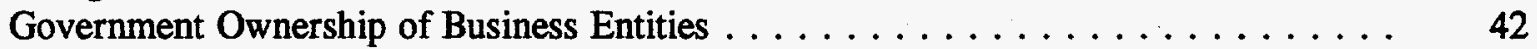

Government Ownership of Natural Resources . . . . . . . . . . . . . . . . . 42

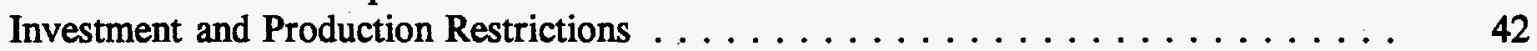

Distribution Restrictions $\ldots \ldots \ldots \ldots \ldots \ldots \ldots \ldots \ldots \ldots \ldots \ldots$

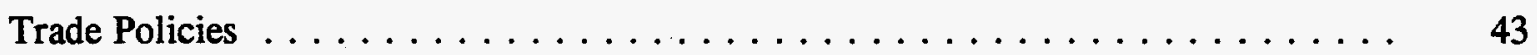

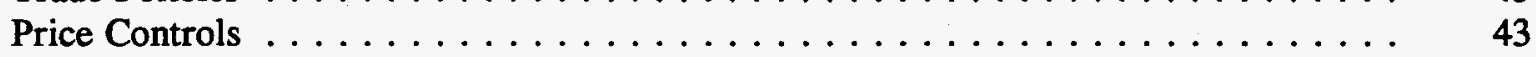

Taxes ............................. 43 
Refined Oil $\ldots \ldots \ldots \ldots \ldots \ldots \ldots \ldots \ldots \ldots \ldots \ldots \ldots \ldots \ldots$

Background . . . . . . . . . . . . . . . . . . . . . 44

Government Ownership of Business Entities . . . . . . . . . . . . . . . 44

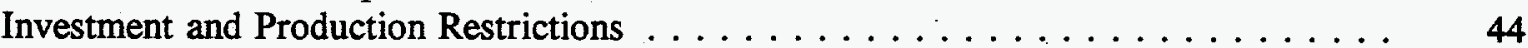

Distribution Restrictions $\ldots \ldots \ldots \ldots \ldots \ldots \ldots \ldots \ldots \ldots \ldots$

Trade Policies . . . . . . . . . . . . . . . . . . . . . . 44

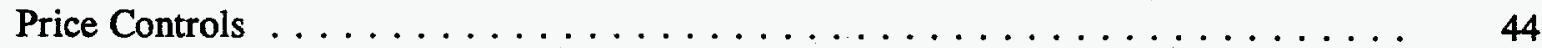

Taxes ................................... 44

Natural Gas $\ldots \ldots \ldots \ldots \ldots \ldots \ldots \ldots \ldots \ldots \ldots \ldots \ldots \ldots \ldots \ldots \ldots \ldots$

Background .............................. 45

Government Ownership of Business Entities . . . . . . . . . . . . . . . . 45

Government Ownership of Natural Resources . . . . . . . . . . . . . . 45

Investment and Production Restrictions . . . . . . . . . . . . . . 45

Distribution Restrictions $\ldots \ldots \ldots \ldots \ldots \ldots \ldots \ldots \ldots \ldots \ldots \ldots$

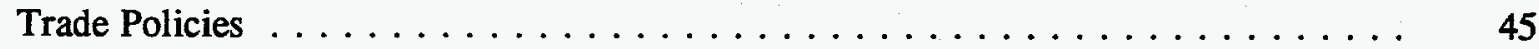

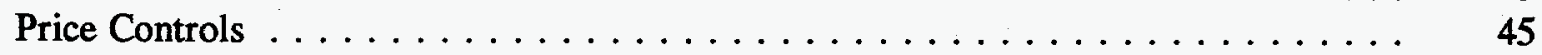

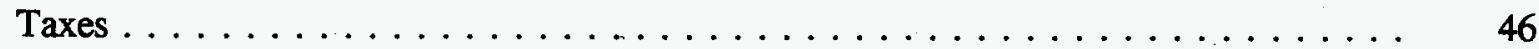

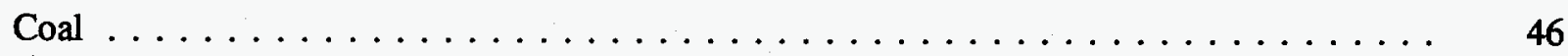

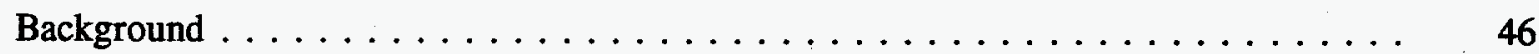

Government Ownership of Business Entities . . . . . . . . . . . . . . 46

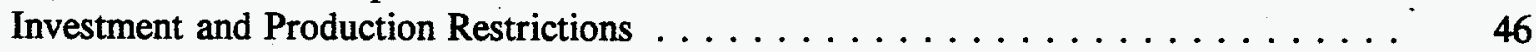

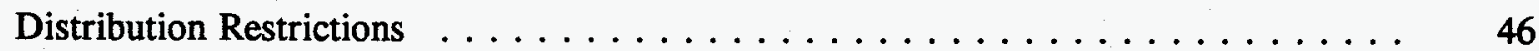

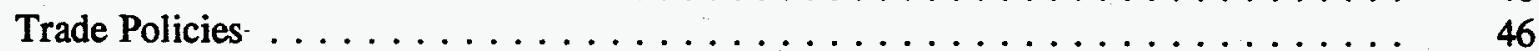

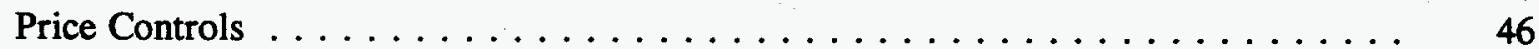

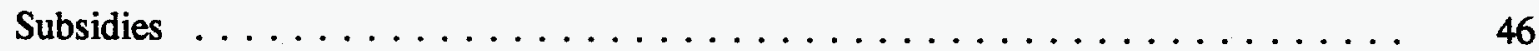

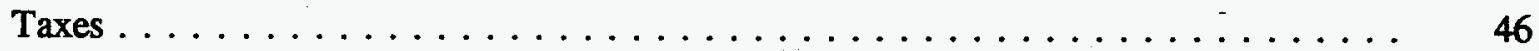

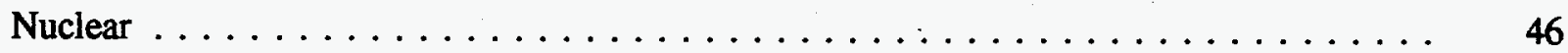

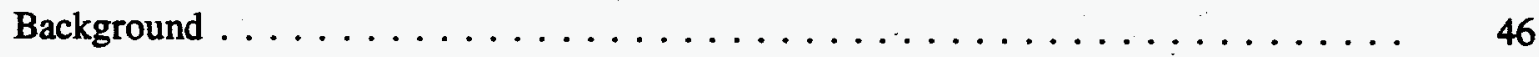

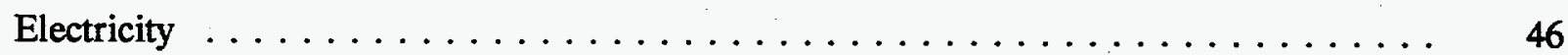

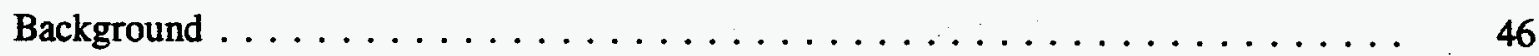

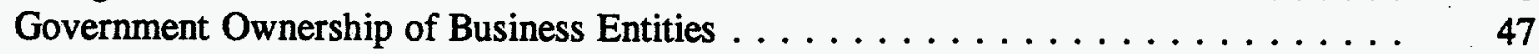

Investment and Production Restrictions $\ldots \ldots \ldots \ldots \ldots \ldots \ldots \ldots \ldots \ldots$

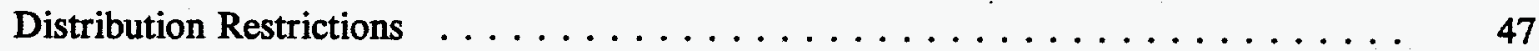

Trade Policies $\ldots \ldots \ldots \ldots \ldots \ldots \ldots \ldots \ldots \ldots \ldots \ldots \ldots \ldots \ldots$

Price Controls $\ldots \ldots \ldots \ldots \ldots \ldots \ldots \ldots \ldots \ldots \ldots \ldots \ldots \ldots \ldots$ 
The Netherlands $\ldots \ldots \ldots \ldots \ldots \ldots \ldots \ldots \ldots \ldots \ldots \ldots \ldots$

All Sectors $\ldots \ldots \ldots \ldots \ldots \ldots \ldots \ldots \ldots \ldots \ldots \ldots \ldots \ldots \ldots \ldots \ldots \ldots$

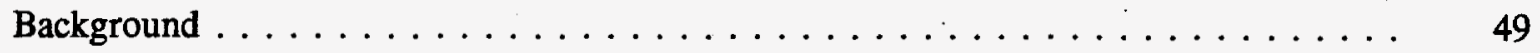

Energy Supply . . . . . . . . . . . . . . . . . . . . . 49

Trade . . . . . . . . . . . . . . . . . . . . . . . 49

Policies . . . . . . . . . . . . . . . . . . . . . 49

Government Ownership of Business Entities . . . . . . . . . . . . . . 49

Energy and the Environment . . . . . . . . . . . . . . . 49

Government-Sponsored R\&D . . . . . . . . . . . . . . . . 50

Taxes ............................... 50

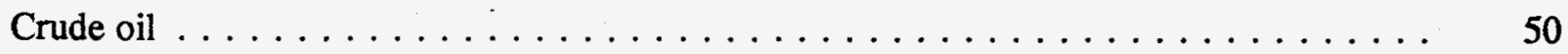

Government Ownership of Business Entities . . . . . . . . . . . . . 50

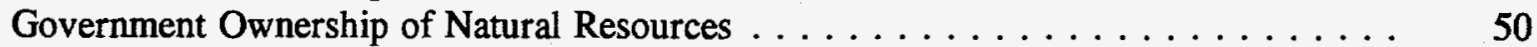

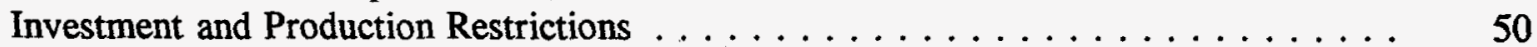

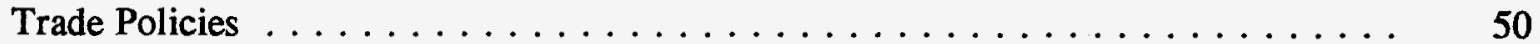

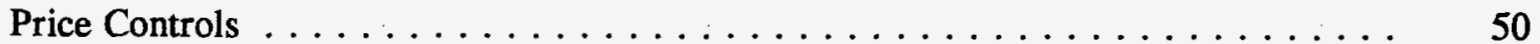

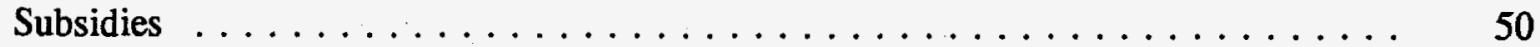

Taxes . . . . . . . . . . . . . . . . . 50

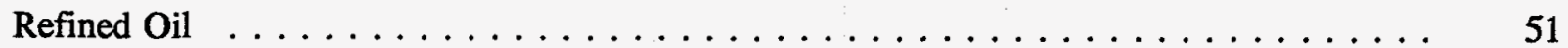

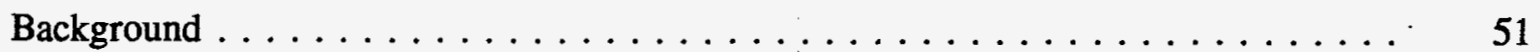

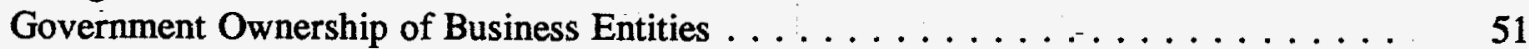

Investment and Production Restrictions $\ldots \ldots \ldots \ldots \ldots \ldots \ldots \ldots \ldots \ldots$

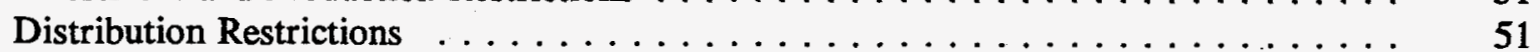

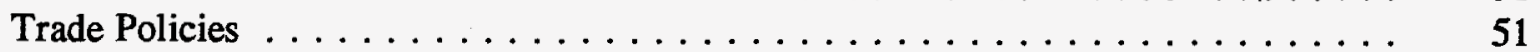

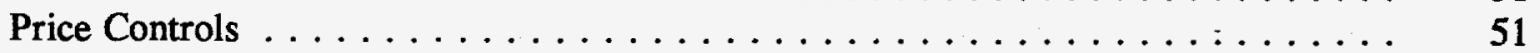

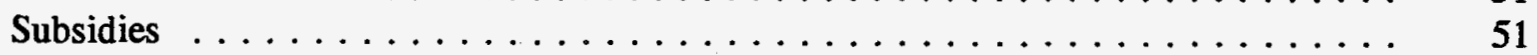

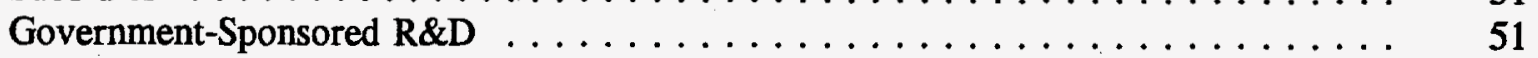

Taxes .................................. 51

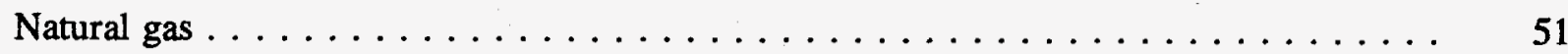

Government Ownership of Business Entities . . . . . . . . . . . . . . 51

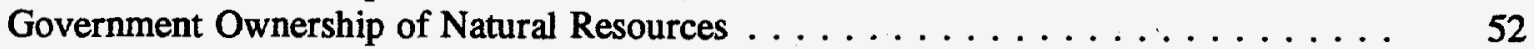

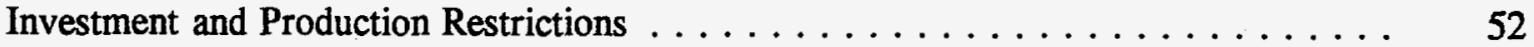

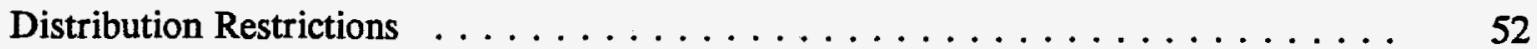

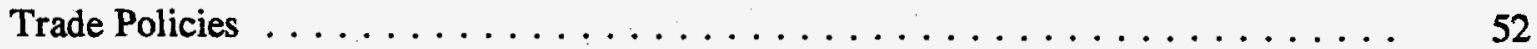

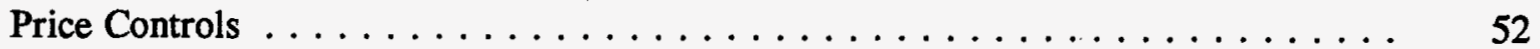

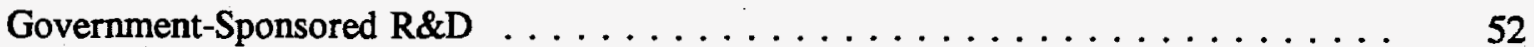

Taxes . . . . . . . . . . . . . . . . . . . . . . . . . . 52 
Background . . . . . . . . . . . . . . . . . . . . 52

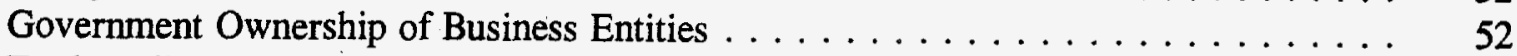

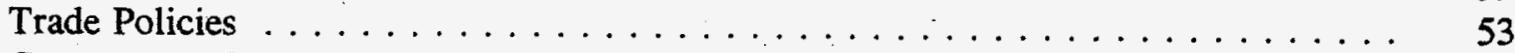

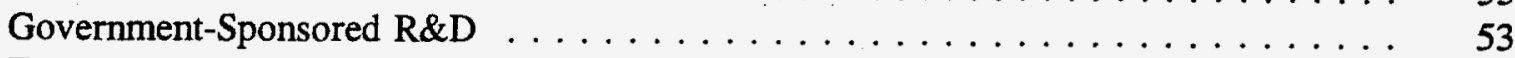

Taxes . . . . . . . . . . . . . . . . . . . . . . . 53

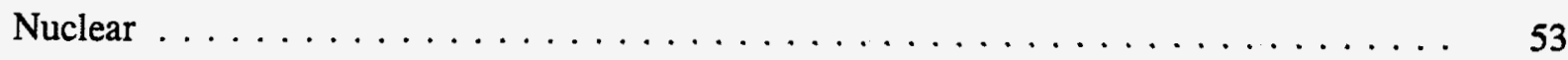

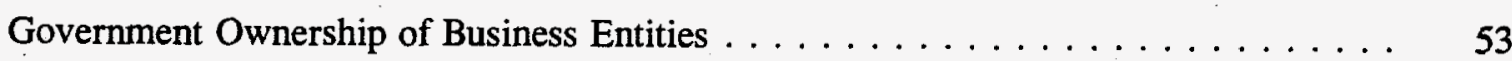

Government-Sponsored $\mathrm{R} \& \mathrm{D} \ldots \ldots \ldots \ldots \ldots \ldots \ldots \ldots \ldots \ldots$

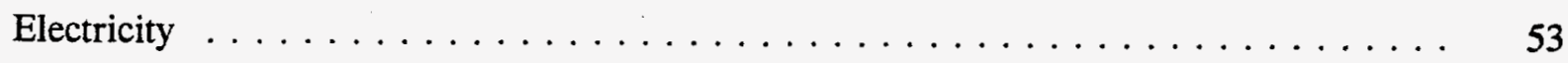

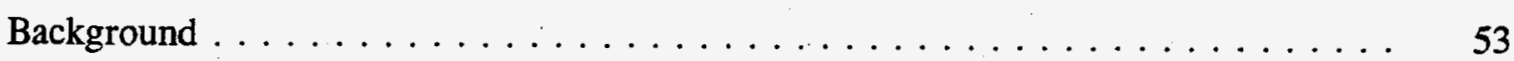

Government Ownership of Business Entities . . . . . . . . . . . . . 53

Investment and Production Restrictions $\ldots \ldots \ldots \ldots \ldots \ldots \ldots \ldots \ldots$

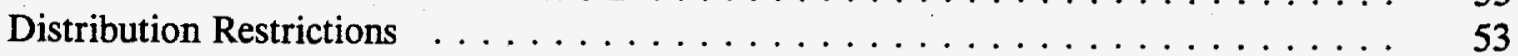

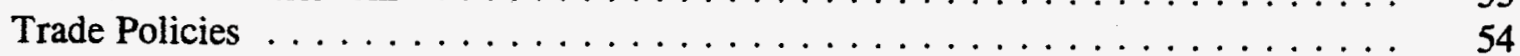

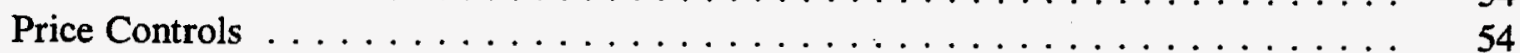

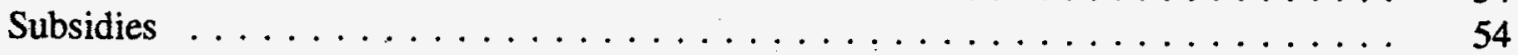

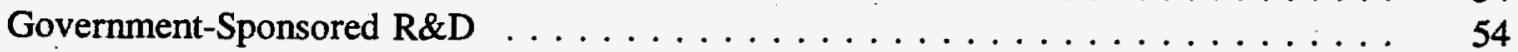

Taxes ............................... 54

Renewable Energy . . . . . . . . . . . . . . . . . . . . 54

Background . . . . . . . . . . . . . . . . . . . . . 54

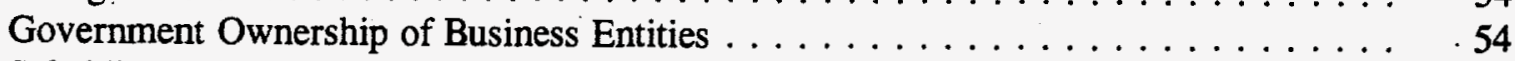

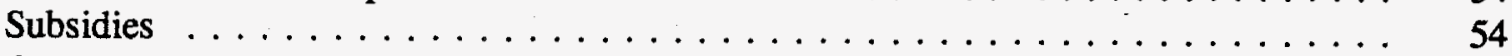

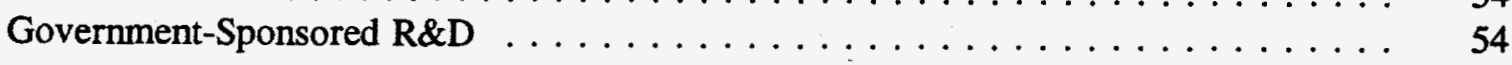

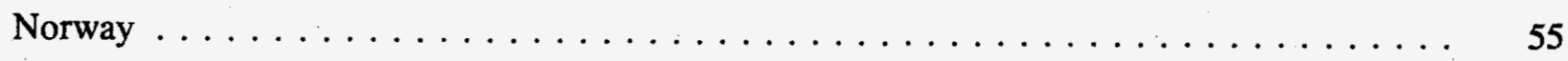

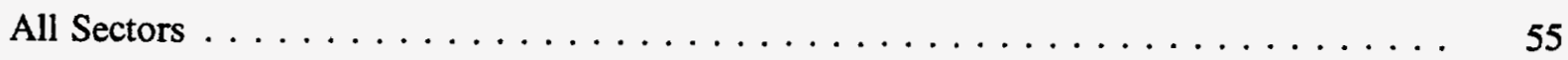

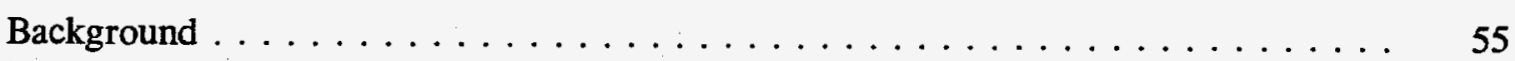

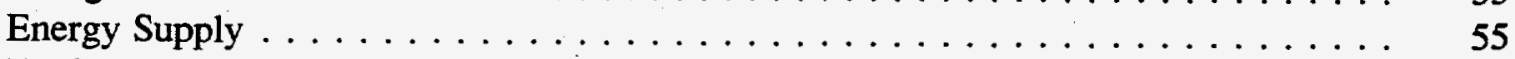

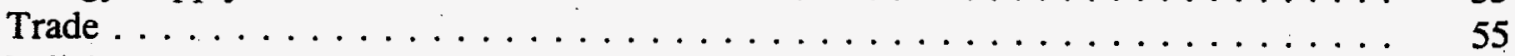

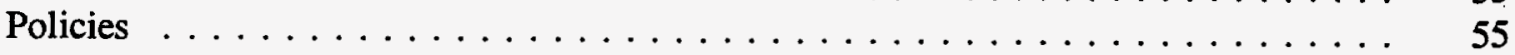

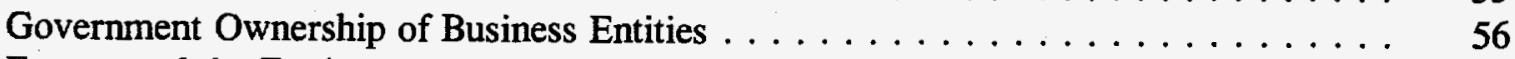

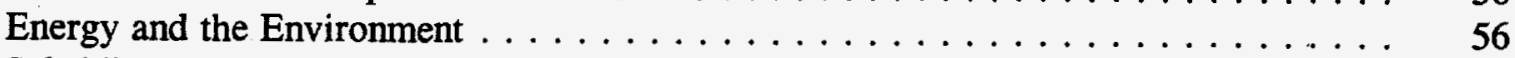

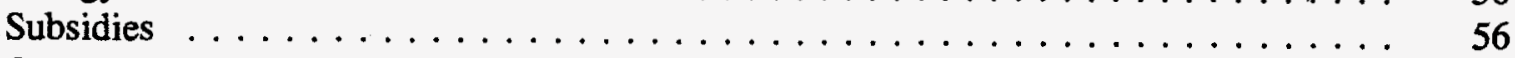

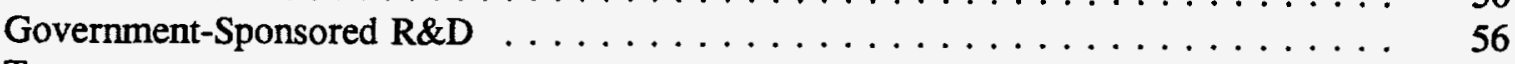

Taxes ................................ 56 


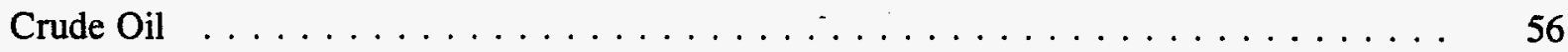

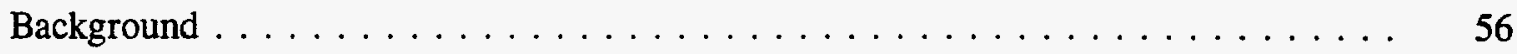

Government Ownership of Business Entities . . . . . . . . . . . . 56

Government Ownership of Natural Resources . . . . . . . . . . . . . . . 57

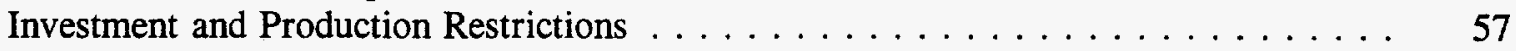

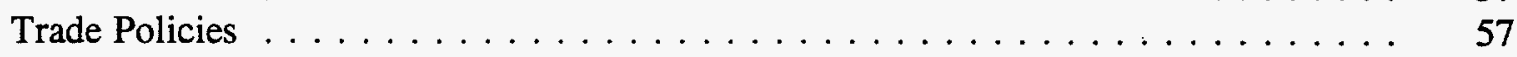

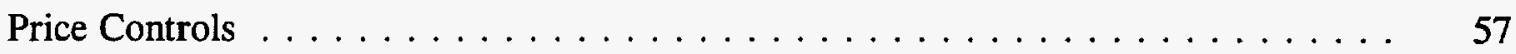

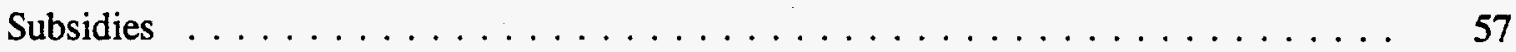

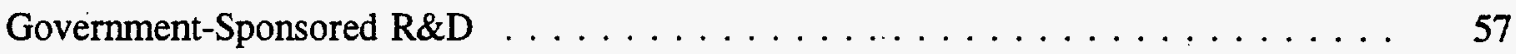

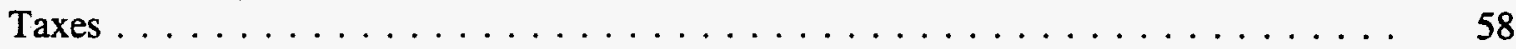

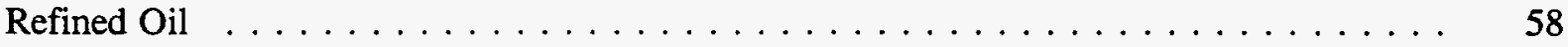

Government Ownership of Business Entities $\ldots \ldots \ldots \ldots \ldots \ldots$

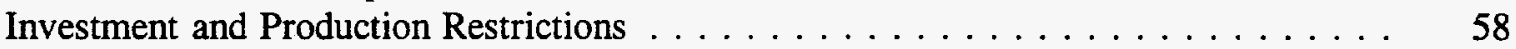

Distribution Restrictions $\ldots \ldots \ldots \ldots \ldots \ldots \ldots \ldots \ldots$

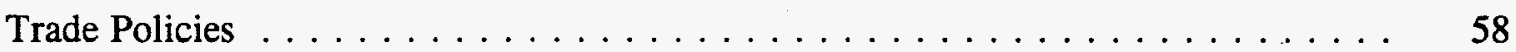

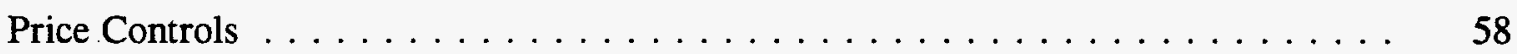

Taxes ............................. 58

Natural Gas . . . . . . . . . . . . . . . . . . . . . 59

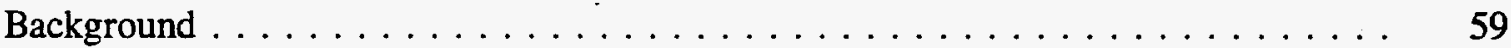

Government Ownership of Business Entities . . . . . . . . . . . . . . 59

Government Ownership of Natural Resources . . . . . . . . . . . . . . . . 59

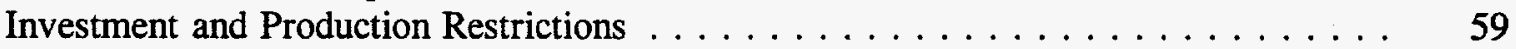

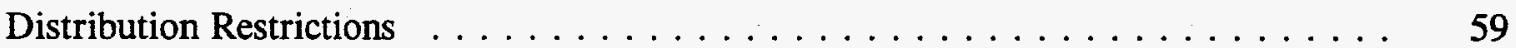

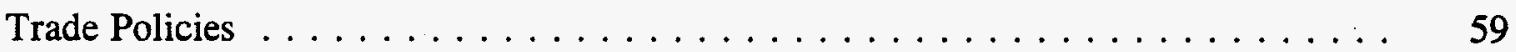

Price Controls . . . . . . . . . . . . . . . . . . . . . . 59

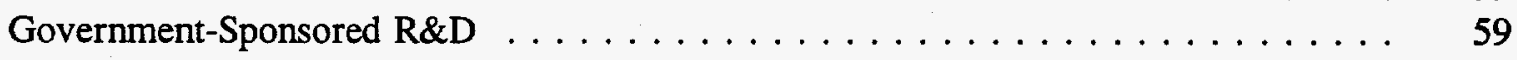

Taxes . . . . . . . . . . . . . . . . . . . . . . . . 59

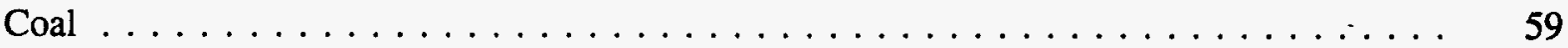

Government Ownership of Business Entities . . . . . . . . . . . . . . 59

Government Ownership of Natural Resources . . . . . . . . . . . . . . . . 60

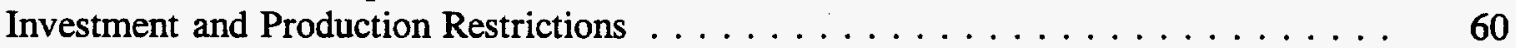

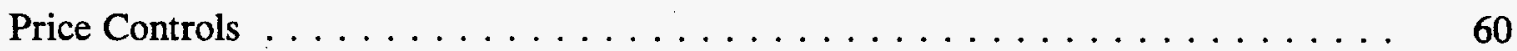

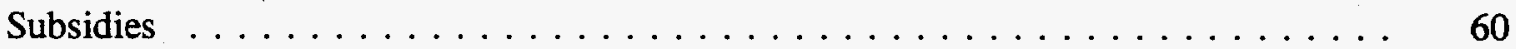

Taxes ............................. 60

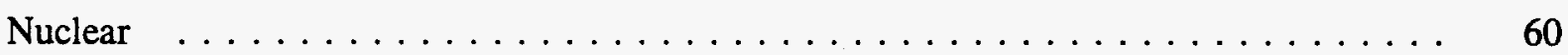

Background .......................... 60 


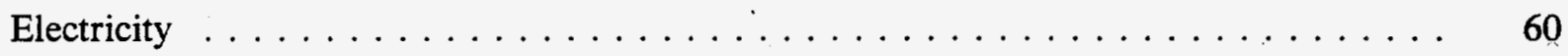

Background . . . . . . . . . . . . . . . . . . . . . 60

Government Ownership of Business Entities . . . . . . . . . . . . . . 60

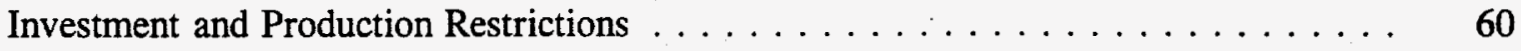

Distribution Restrictions . . . . . . . . . . . . . . . . . . . 60

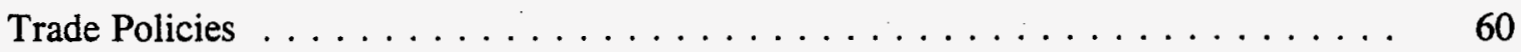

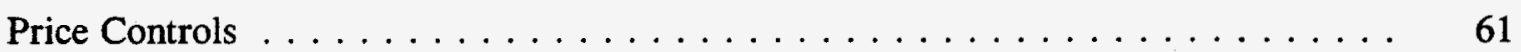

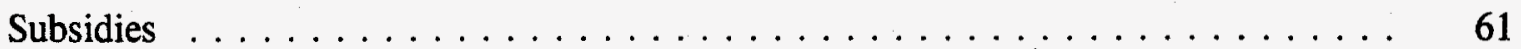

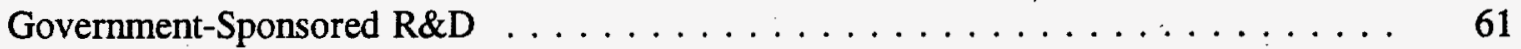

Taxes . . . . . . . . . . . . . . . . . . . . . . . . . . . . 61

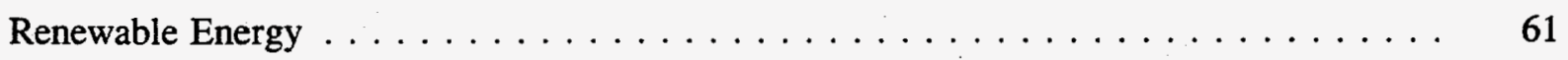

Background . . . . . . . . . . . . . . . . . . 61

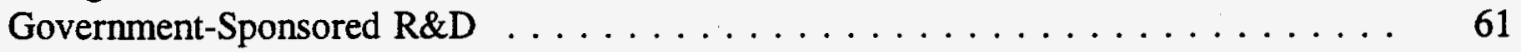

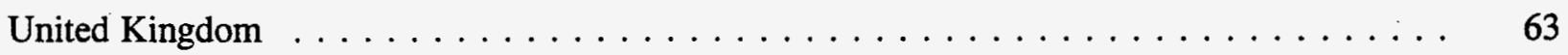

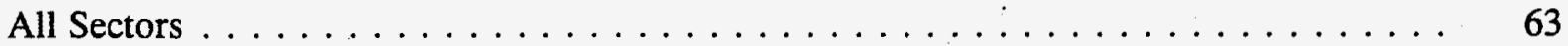

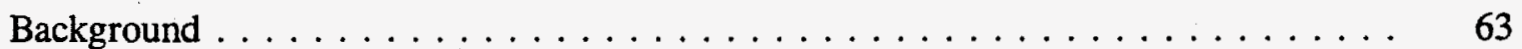

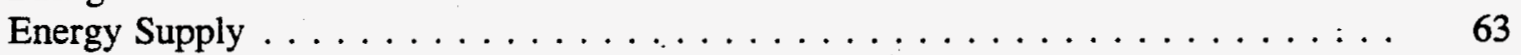

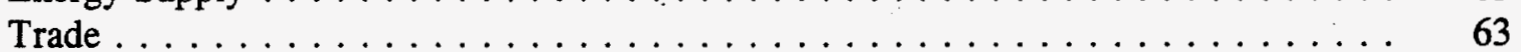

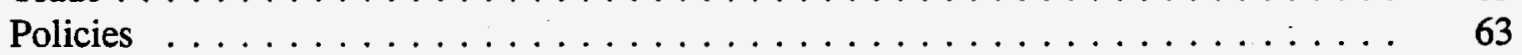

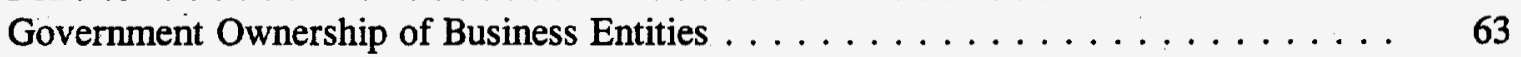

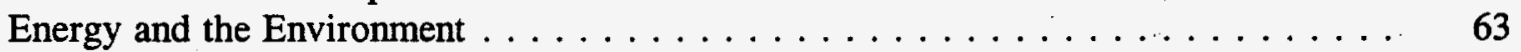

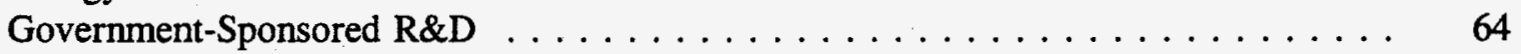

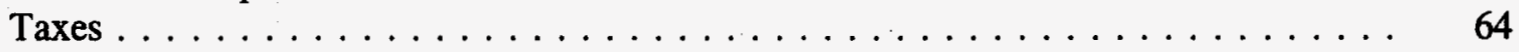

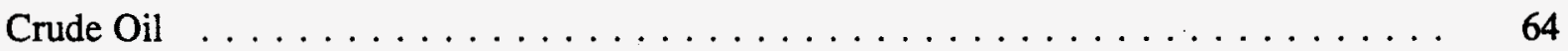

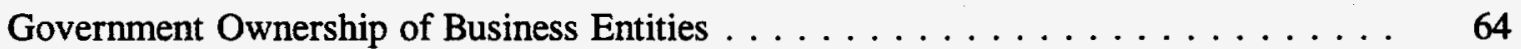

Government Ownership of Natural Resources . . . . . . . . . . . . . . . 64

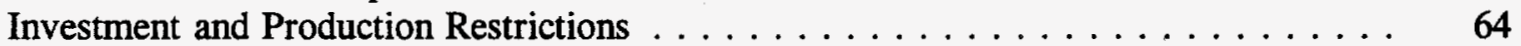

Trade Policies . . . . . . . . . . . . . . . . . . . . . . . 64

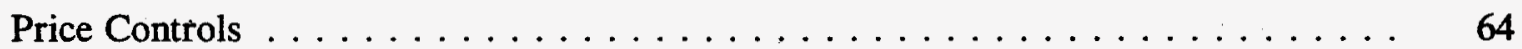

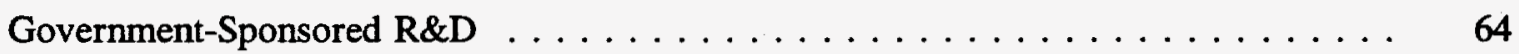

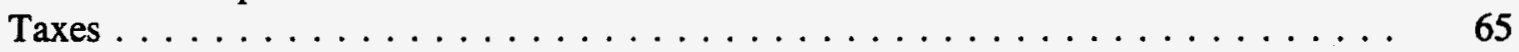

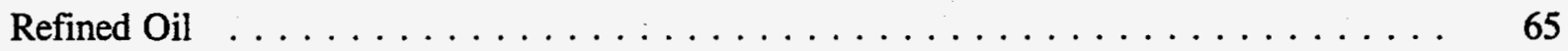

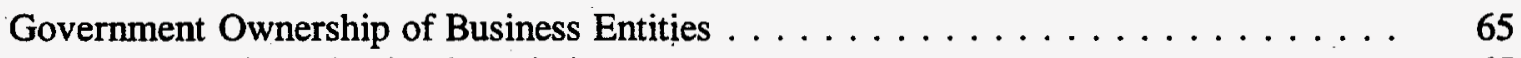

Investment and Production Restrictions $\ldots \ldots \ldots \ldots \ldots \ldots \ldots \ldots \ldots \ldots$

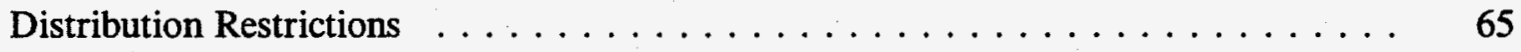

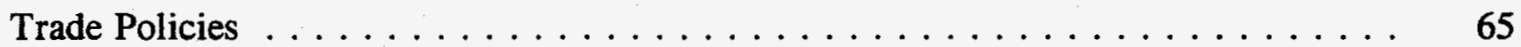

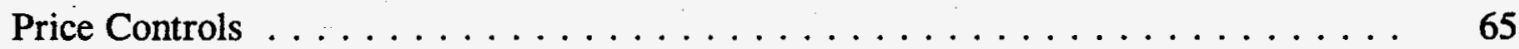

Taxes .................................. 65 


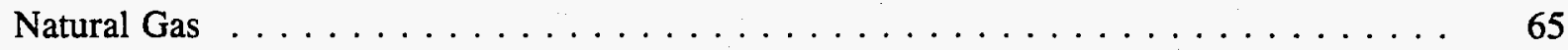

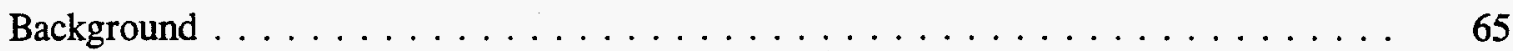

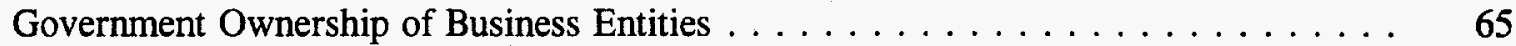

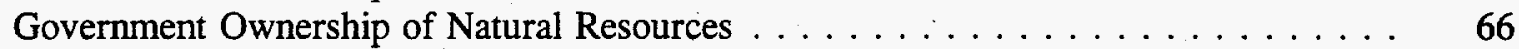

Investment and Production Restrictions $\ldots \ldots \ldots \ldots \ldots \ldots \ldots \ldots \ldots 66$

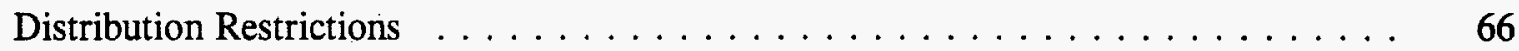

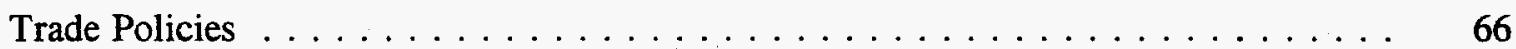

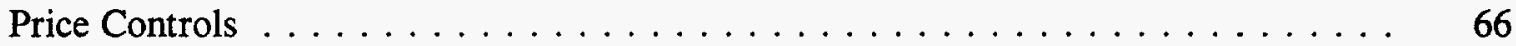

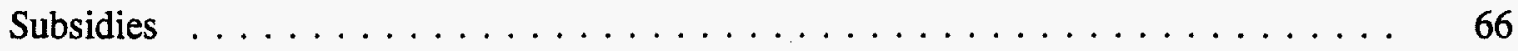

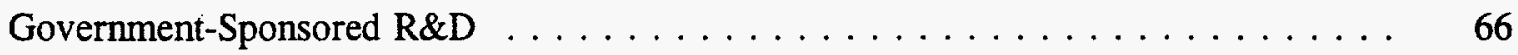

Taxes ................................ 66

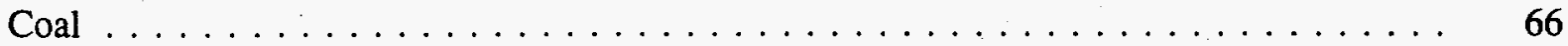

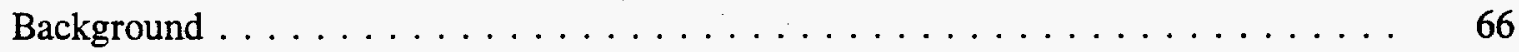

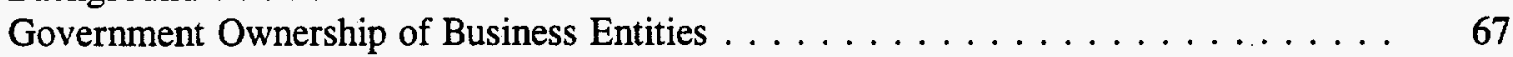

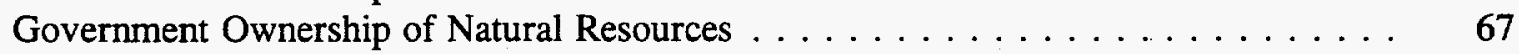

Investment and Production Restrictions $\ldots \ldots \ldots \ldots \ldots \ldots \ldots \ldots \ldots 67$

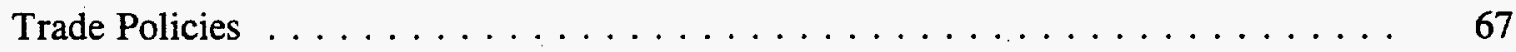

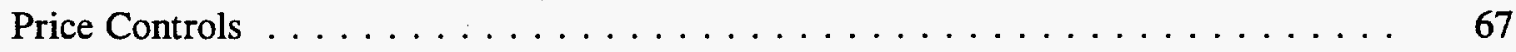

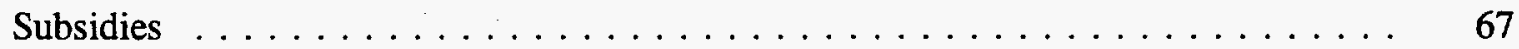

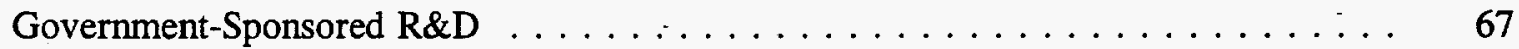

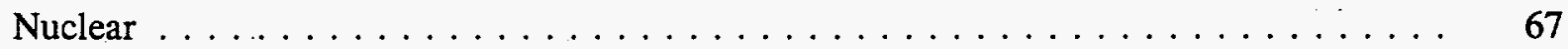

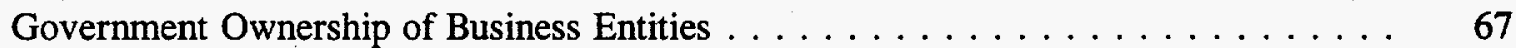

Production Restrictions $\ldots \ldots \ldots \ldots \ldots \ldots \ldots \ldots \ldots \ldots \ldots \ldots$

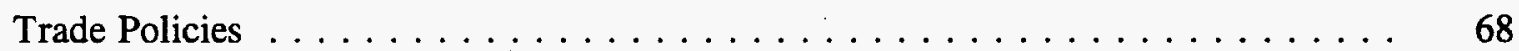

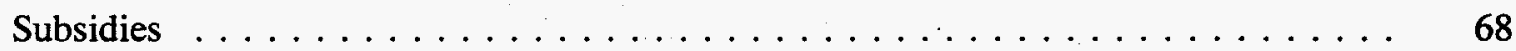

Government-Sponsored R\&D $\ldots \ldots \ldots \ldots \ldots \ldots \ldots \ldots \ldots \ldots \ldots$

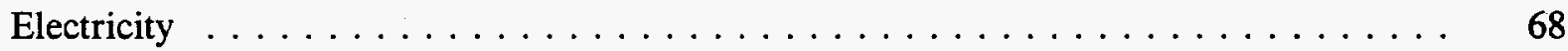

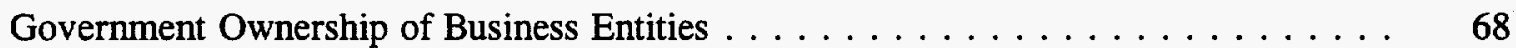

Investment and Production Restrictions $\ldots \ldots \ldots \ldots \ldots \ldots \ldots$

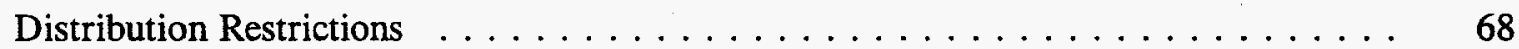

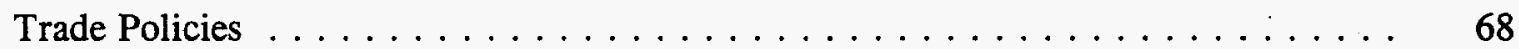

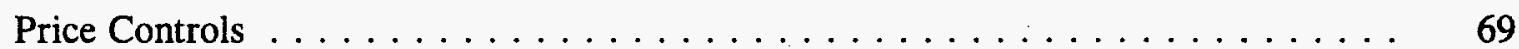

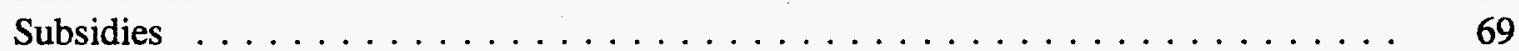

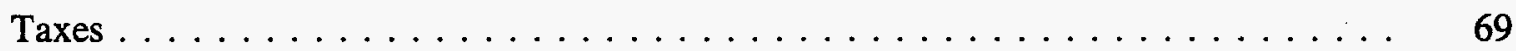

Renewable Energy $\ldots \ldots \ldots \ldots \ldots \ldots \ldots \ldots \ldots \ldots \ldots \ldots \ldots \ldots$

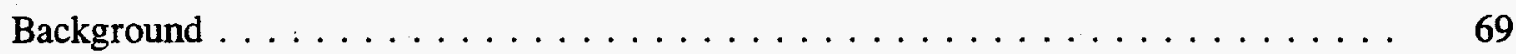

Investment and Production Restrictions $\ldots \ldots \ldots \ldots \ldots \ldots \ldots \ldots \ldots \ldots .6 \%$

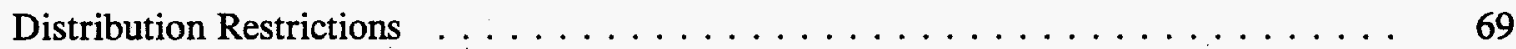

Trade Policies . . . . . . . . . . . . . . . . . . . . . 69 


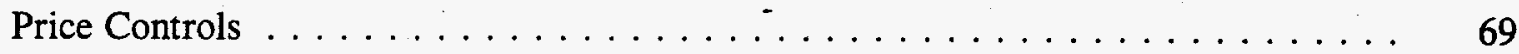

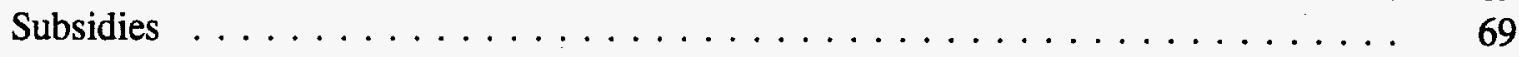

Government-Sponsored R\&D . . . . . . . . . . . . . . . 69

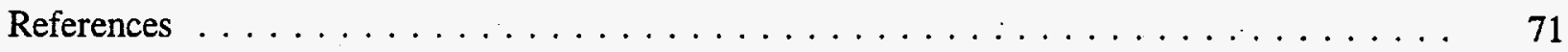

Telephone or Fax Interviewees $\ldots \ldots \ldots \ldots \ldots \ldots \ldots \ldots \ldots \ldots$

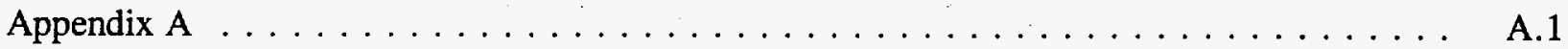




\section{Introduction}

This report provides background documentation to a companion report titled Energy Company Competitiveness: Little To Do With Subsidies (DOE 1994). Accordingly, this publication consists of information found during the course of research for the DOE study relating to major government energy policies in each country studied. In addition, this report provides a brief summary of the findings of the DOE report.

In October 1993, the Office of Energy Intelligence, U.S. Department of Energy (formerly the Office of Foreign Intelligence), requested that Pacific Northwest Laboratory prepare a report addressing policies and actions used by foreign governments to enhance the competitiveness of their energy firms. The purpose of this report was to provide U.S. policymakers in the Department of Energy a clear view of the policies and actions employed by foreign governments in helping their energy companies, with the view of examining how U.S. policy options might assist U.S. energy companies in developing competitive strategies for the 1990's. Two separate reports were prepared as a result of this request. The first, Energy Company Competitiveness: Little To Do With Subsidies (DOE 1994), provides an overview on the policies and actions pursued by foreign governments to enhance their energy firms' competitiveness. This DOE report also looks at U.S. policies and their impact on the competitiveness of foreign and U.S. energy companies in the global market. The second report, which is the content of this publication, provides a country-by-country listing of the information found during the course of research on the DOE study.

The information presented in this report was compiled through surveying open-source (mostly trade-related) publications concerning the topics listed above and through personal interviews. Where feasible, quantitative measures of performance were presented, but the availability of quantitative . measures is limited.

Competitiveness and policies that affect energy firms' competitiveness are broad topics and, therefore, are not treated in great detail in this or the DOE report. Indeed, certain issues affecting competitiveness, such as environmental regulations or taxation, could easily warrant entire studies by themselves. Because the topic of competitiveness and the issues affecting it are so complex, the analysis is in large measure qualitative, and accordingly, the following limitations are noted:

- The data is based heavily on second-hand sources and personal interviews. Note that some of the costs of environmental regulation in the oil and natural gas industry were derived from sources who hold an industry point of view.

- The policies of the countries examined are rapidly changing. Despite the fact that efforts were made to provide the most up-to-date information by extensively interviewing people who are knowledgeable about the countries in question, these rapid changes should be kept in mind. 
The main body of this report summarizes major government policies, country by country and energy sector by energy sector. The countries examined are the United States, Australia, Canada, France, Mexico, the Netherlands, Norway, and the United Kingdom. Sectors covered include the following:

- crude oil

- oil refining

- natural gas

- coal

- nuclear power

- electricity

- renewable energy.

Among the topics covered in the individual sectors are government ownership of business entities and natural resources; investment, production, and distribution restrictions; trade policies; price controls; subsidies; and government-sponsored research and development. ${ }^{\text {(a) }}$ In the appendix to this report, Table A.1 lists production, trade, and consumption of energy by country for each sector and Tables A.2-A.9 summarize energy restrictions by country and sector.

Germany and Japan, although mentioned in the main report (DOE 1994), are not specifically examined here because they are not currently large players in either crude oil and natural gas production or coal exports. Communications with industry indicated that they subsidized the cost of exploration for their oil companies. ${ }^{(b)}$ Reference materials also indicated that they heavily subsidized coal production but were only involved in exports to a negligible degree (IEA 1992c).

(a) Certain topics for individual sectors have been omitted in cases where no information was found.

(b) Personal communications with Gordon Barrows, Barrows and Company, 4/4/94; Dennis O'Brien, Chief Economist, Caltex, 3/31/94; Reginald Spiller, Deputy Assistant Secretary for Natural Gas and Petroleum, U.S. Department of Energy; Clement (Clem) Malin, Manager, International Government Relations, Texaco, 4/12/94. 


\section{Summary of Energy Company Competitiveness: Little To Do With Subsidies (DOE 1994)}

Foreign governments are liberalizing their energy regimes to attract foreign capital and increase productive capacity. Governments are privatizing major oil and gas firms, providing less direct subsidization, and giving less preferential treatment to their domestic firms. Nevertheless, foreign governments continue to play a very important, indirect role in providing their energy firms with a competitive edge.

Lower environmental costs in foreign countries provide a competitive edge to foreign energy companies in their domestic markets. These lower costs, combined with foreign business standards that are different from those in the United States, afford foreign companies significant advantages in conducting business in the energy sector.

\section{Foreign Environmental and Business Regulations Provide}

\section{Cost Advantage}

The rest of the world lags behind the United States in implementing environmental, health, and safety regulations governing exploration, production, and development of natural resources in the energy sector. Less tightly enforced regulations in areas other than the United States provide foreign energy firms relatively lower costs and, in some cases (particularly in oil exploration, development, and refining), these lower costs entice foreign and U.S. companies to produce outside of the United States. Companies from the United States that do not have the capital to relocate outside of the United States are placed at a competitive disadvantage to foreign and multinational firms.

Similarly, the Australian and Canadian coal industries, two main U.S. competitors, pay less environmental and health taxes, in general, than the U.S. coal industry does. Although Australian and Canadian producers have higher direct coal production costs, their lower environmental, health, safety, and transportation costs give them a competitive edge over U.S. producers.

Different foreign business standards from those adopted by the United States sometimes give foreign energy companies an advantage over U.S. companies in global markets. ${ }^{(a)}$ Unlike the United States, many foreign governments continue to allow their companies to conduct business with countries that the United States identifies as supporting terrorism or committing acts of war. In

(a) Foreign firms also benefit from some U.S. policies. The export embargo on Alaska North Slope (ANS) crude oil depresses U.S. west-coast oil market prices and reduces profits compared with foreign-produced oil. In addition, the Jones Act requires oil and coal shipped between U.S. ports to be carried on higher-cost, U.S.-flagged ships. Oil and coal from foreign ports can be carried on lower-cost, foreign-flagged carriers. France and Canada have similar shipping laws. 
addition, other countries permit practices that the United States proscribes as corrupt and prohibits under the Foreign Corrupt Practices Act (FCPA) ${ }^{(a)}$. Countries that allow their foreign companies to use kickbacks and bribery to win contracts may give their firms an advantage over U.S. firms in conducting business in foreign countries.

\section{Foreign Government Involvement}

United States oil and natural gas companies increasingly find the business environment provided by foreign governments open for exploration and development. Most countries are removing longstanding barriers to energy production. All countries studied, except Mexico, are privatizing their energy sectors in order to increase domestic supplies and reduce their reliance on imports. Government revenue generation and energy security drives much of the privatization. Even Mexico skirts constitutional restrictions in order to stimulate more production of oil and natural gas.

Still, there are a number of foreign countries where privatization in the energy sector is not complete and there are lingering hints of preferential treatment and subsidies. In the oil and natural gas sector, most government-owned companies are being sold or no longer receive preferential treatment. Yet, some U.S. companies, based on past experience, perceive that foreign governments provided greater assistance to their domestic companies, such as Statoil, Elf, and Total, than is currently being given.

Subsidies to foreign coal companies in Canada, France, Germany, Japan, Norway, and the United Kingdom potentially reduce U.S. and Australian coal exports (IEA 1992c). Canada, Germany, and the United Kingdom have substantial coal production, but together still account for only $45 \%$ of U:S. production and $17 \%$ of Organization for Economic Cooperation and Development (OECD) exports. The coal sector is moving towards privatization with the exceptions of France, Germany, and Japan.

Some U.S. companies directly benefit from subsidization by foreign governments. Many oil and natural gas exploration and development projects are undertaken by consortia of companies because of the size of the investment capital required and the desire to spread risk. Some countries such as Japan and Canada are providing a share of the equity capital for these consortia in which U.S. companies are involved.

(a) Foreign Corrupt Practices Act of 1977, Public Law No. 95-213, Title I, 91 Stat. 1494 [codified at 15 U.S.C. $\$ \S 78 \mathrm{a}, 78 \mathrm{~m}, 78 \mathrm{dd}-1,78 \mathrm{dd}-2,78 \mathrm{ff}$ (Supp. III, 1979) (amending scattered sections of the Securities Exchange Act of 1934, 15 U.S.C. \$\$ 77a-78kk (1976)]; and Domestic and Foreign Investment Improved Disclosure Act of 1977 Public Law No. 95-213, Title II, 91 Stat. 1498 [codified at 15 U.S.C. §§ 78a, 78kk, (Supp. III 1979) (amending scattered sections of the Securities Exchange Act of 1934, 15 U.S.C. $\$ \S 78 \mathrm{a}-78 \mathrm{kk}$ (1976)]. Both titles are commonly known as the Foreign Corrupt Practices Act. 


\title{
United States
}

\begin{abstract}
All Sectors
Background: The United States is the largest consumer and probably the biggest producer of energy in the World (IEA 1992c).
\end{abstract}

Energy Supply: Together, fossil fuels account for about $85 \%$ of the U.S. total primary energy supply, with oil accounting for about $38 \%$; gas, $24 \%$; and coal, $23 \%$. Nuclear power, renewable energies, and electricity imports account for the remaining balance of energy use (IEA 1993a).

Trade: In 1991, the United States imported approximately $21 \%$ of total final consumption (TFC) of energy, primarily in the form of oil and natural gas, but primarily oil (IEA 1993a).

Policies: The State and Federal Governments share responsibility for energy policy. While Federal statutes are obligatory, many states pass statutes of their own which are more stringent than the Federal laws. The Department of Energy (DOE) provides the lead on U.S. energy policy, but other agencies, including the Nuclear Regulatory Agency, Department of Transportation, the Environmental Protection Agency (EPA), and the Department of Interior, all play an active role (IEA 1992c).

The National Energy Strategy's (NES), 1991, basic objectives are to provide for a balance between the growing need for reasonably priced oil and environmental concerns while remaining committed to the maintenance and growth of the U.S. economy. The reliance on market forces was a keystone of the strategy (IEA 1992c). Elements of the NES were implemented through the Energy Policy Act of 1992 (EPACT) (Public Law 102-486). Other parts of the NES were implemented through the rulesmaking and regulation process (IEA 1993a).

The EPACT provides for tax breaks for independent oil and gas producers; reform of the Public Utility Holding Company Act 1935 (PUHCA) (15 U.S.C \$ 79) to allow broader competition in wholesale electricity generation; tax incentives for renewables and alternative fuels; and reform of the licensing process to encourage nuclear power plant construction (IEA 1993a).

The DOE estimates that the EPACT has the potential to reduce U.S. oil imports by 4.7 million barrels per day (mbd) and total energy demand by over $9 \%$ by 2010 . The share of renewables in Total Primary Energy Supply (TPES) is projected to rise to $12 \%$ by 2010 , compared with $9 \%$ without the EPACT, and the share of coal is projected to decline to $23 \%$, compared with $27 \%$ without the EPACT. Critics argue that DOE's estimates are ambitious (IEA 1993a).

The U.S. FCPA of 1977 is a law that may have a direct bearing on U.S. firm competitiveness in the international arena. The act makes it illegal for U.S. companies to bribe foreign officials. The law prohibits both offers and promises to pay bribes, or payment of bribes (Levine 1991). Penalties 
include up to a $\$ 1$ million in fines for reporting companies and fines of up to $\$ 10,000$ and up to 5 years imprisonment for any officer, director, or sharehold. Indemnification is not allowed (Stanberry, George, and Ross 1991).

The United States is the only nation that legislates moral business conduct overseas (Singer 1991). The FCPA became law in 1977 after incidents involving the governments of Belgium, the Netherlands, Honduras, Italy, and Japan and U.S. companies (Singer 1991).

Companies, such as Elf Aquitaine, which have subsidiaries with no ties to U.S. companies, can legally use bribery to win contracts. ${ }^{(a)}$ United States companies are unable to compete as aggressively under such circumstances.

The law may have unintended consequences. For example, Young \& Rubicam, a New York-based advertising agency, was accused of having an agent bribe the Jamaican tourism minister. They considered the payment a facilitation payment, which is legal under the FCPA, provided that it is reported. United States Customs, however, charged the company with bribery. They pleaded no contest rather than pay the legal fees to fight the case. Consequently, they no longer allow anyone associated with the company to provide facilitation payments. Young \& Rubicam claim that they are losing sales as a result (Singer 1991).

The United States places restrictions on conducting business with other countries, such as Cuba, Libya, Iraq, Iran, and formerly Angola and Vietnam (DOS 1994).

The U.S. Congress has passed legislation which imposed a moratoria on the exploration and development of gas and oil in the Arctic National Wildlife Refuge (ANWR) and on parts of the Outer Continental Shelf (OCS) (IEA 1992c).

Government Ownership of Business Entities: Energy companies are in the private sector, except for a small percentage of electricity generation by the Federal Power Administration (IEA 1992c; EAI 1992b).

Energy and the Environment: The United States is a signatory of the Framework on Climate Change. Some U.S. environmental laws affecting U.S. energy competitiveness include the Alternative Motor Fuels Act, 1988 (Public Law 100-494); the Clean Air Act of 1955 (42 U.S.C. 7401 et seq.), especially the Clean Air Act Amendments of 1990 (Public Law 101-549); the Clean Water Act (30 U.S.C. §§ 1251-1376); the Oil Pollution Act of 1990 (33 U.S.C 2701 et seq.); and the Surface Mining Control and Reclamation Act of 1977 (30 U.S.C. $\$ \S ~ 1201-1329)$ (IEA 1992c; Rozenzweig 1993; Singer 1991).

No foreign country regulates air, water, and pollution compliance in total as strictly as the United States. However, in individual compliance areas, some countries may have higher standards than those

(a) Personal communications with Kumar Bhattacharjee, world-wide independent natural gas and oil explorer, Houston, Texas, 4/12/94. 
of the United States. For example, until the United States passed the Clean Air Act Amendments of 1990 , only Japan had tougher clean air standards than the United States. In addition, countries that have standards as high as the United States may have less strict implementation and more flexibility in meeting the standards. The United States gives less financial and technical assistance to industry to comply with environmental regulations than other countries, such as Germany and Japan. Most European nations, in contrast to the United States, supplement regulation with help in developing technologies that reduce pollution (OTA 1994).

Foreign countries lag behind the United States by 5 to 20 years in the implementation of environmental, safety, and health regulations, according to a Bechtel report done for the Independent Refiners Coalition. The report shows that foreign countries will probably still be no closer than $90 \%$ of the level of U.S. regulatory implementation by 2010 . Most regions will reach only $50 \%$ of the U.S. regulatory level by 2010 . According to the report, the costs of the last $50 \%$ of implementation measures are significantly higher than the first $50 \%$ of implementation measures. ${ }^{\text {(a) }}$

According to the Congressional Office of Technology Assessment, environmental costs for all U.S. industries grew from $\$ 52$ billion in 1972 to $\$ 108$ billion in 1990 (1990 dollars). Environmental costs are likely to rise to $\$ 147$ billion by the year 2000 . In 1990 , environmental costs accounted for $1.95 \%$ of the Gross National Product (GNP). Private sector costs in 1990 were about $0.86 \%$ of the GNP in 1990. By 2000 , these costs to U.S. industry will account for $2.25 \%$ of the GNP (OTA 1994). The OECD estimates are slightly lower but the growth rates are similar. The OECD estimates that about $1.5 \%$ of the U.S. Gross Domestic Product (GDP) and \$313 per capita was spent on environmental equipment and protection (OECD 1992). ${ }^{\text {(b) }}$

Private sector environmental sales are about $1.72 \%$ of the overall value added by the U.S. industry. For process industries like chemicals and petroleum, the pollution abatement costs can be significant. As a share of value added, the petroleum industry spent about $\$ 3.4$ billion or $15.4 \%$ of the total U.S. environmental abatement costs in 1991. For the petroleum industry, the total environmental expenditures are about $2.5 \%$ of sales. Petroleum industry capital expenditures totaled $\$ 1.5$ billion or about $25.7 \%$ of all capital expenditures. Some of the cost differential between U.S. firms and foreign firms may be due to the efficiency of the regulatory systems, but most of the difference is due to the level of enforcement (OTA 1994).

(a) Bracewell and Patterson, L.L.P. Submission to the U.S. Department of Commerce concerning "Comments on the Initiation of National Security Investigation of Imports of Crude Oil and Petroleum Products." Washington, D.C., 6/12/94.

(b) Organization for Economic Co-operation and Development (OECD), "Environmental Cost and Industrial Competitiveness." OECD, Paris, France. Restricted document, draft, 5/20/92. 
The 1990 Oil Pollution Act is estimated to cost the United States the equivalent of approximately 2 mbd of oil. It affects small and mid-sized operators the most. The act requires operators to show $\$ 150$ million in liability insurance. Large operators' (over 50,000 barrels per day [bd]) insurance costs are likely to be around $\$ 0.01$ per barrel of oil equivalent. Smaller operators' (less than 50,000 bd) insurance costs will be from $\$ 0.10$ to $\$ 1.09$ per barrel, a significant difference. Small offshore operators account for 120 of the 139 operations (OGJ 1994a).

In 1990, the American Petroleum Institute (API) reported that the U.S. oil industry spent more on environmental activities ( $\$ 8.1$ billion) than on exploration activities in the United States ( $\$ 7.6$ billion). United States oil exploration has declined from $\$ 45$ billion in 1981 (API 1993a). In contrast, according to the API, U.S. oil company exploration overseas accounted for $65 \%$ of the total worldwide exploration in 1992, up from only $30 \%$ in the mid-1980s (API 1993b).

Subsidies: The U.S. government provided a total of $\$ 4.9$ billion in direct and indirect subsidies to energy producers and energy consumers in fiscal year (FY) 1992. The itemized account items for direct expenditures by the government are low income energy assistance, $\$ 1,143$ million; energy services, $\$ 1,743$ million; cost of regulators, $\$ 523$ million; reduction in income taxes, $\$ 2,100$ million; and exemptions from excise taxes, $\$ 460$ million (EAI 1992b).

The Export-Import (EXIM) Bank and the Overseas Private Investment Corporation (OPIC) provide loans and loan guarantees to development projects. In FY 1993, the EXIM Bank provided $\$ 3.5$ billion dollars in loans to development projects in nuclear and non-nuclear power generation, coal mining, and in the oil and gas sector. Congress appropriates funds for the EXIM Bank even though the EXIM Bank charges a fee. The OECD countries have guidelines for determining the level of the fee. These - OECD countries reportedly follow these guidelines most of the time, although occasionally a country may go outside of the guidelines. ( $^{\text {) }}$

Government-Sponsored Research and Development (R\&D): The U.S. Government spent $\$ 2,043$ million on research and development in the energy sector in 1992, about $0.054 \%$ of the GDP. The oil industry received $\$ 75$ million or $3.7 \%$ of the total; gas, $\$ 21$ million, $1.0 \%$; coal, $\$ 551$ million, $27.0 \%$; nuclear power, $\$ 890$ million, $43.6 \%$; renewable energy, $\$ 244$ million, $11.9 \%$; electricity, $\$ 5$ million, $0.2 \%$; and conservation, $\$ 258$ million, $12.6 \%$ (EAI 1992b).

Taxes: Oil companies paid \$3,132 million in excise taxes without offsetting liabilities in 1992 (EAI 1992b).

(a) Personal communications with Kevin O'Connor, Export-Import Bank, 6/9/94, and the ExportImport Bank Fact Sheet, revised 9/92. 


\section{Crude Oil}

Background: The U.S. imports most of its crude oil from Saudi Arabia, Venezuela, Canada, and Mexico. Net oil imports accounted for about 46\% of the TFC in 1991 (IEA 1993a). Gross imports of crude oil climbed $90 \%$ between 1985 and 1992 (DOE 1993).

Government Ownership of Business Entities: There is no government ownership in the business entities involved in the exploration, development, extraction, or marketing of crude oil (IEA 1992c).

Government Ownership of Natural Resources: Unlike other countries, mineral rights belong to the landowner, whether that owner is a private individual, a State, or the Federal government. The Department of the Interior controls the rights for exploration and development of oil on Federal lands or on the OCS. States control oil on their lands (IEA 1992c).

Investment and Production Restrictions: Private investors may lease exploration and development rights, but they are subject to environmental regulations by both the EPA and state environmental departments, as well as regulations on safety and conservation. Some states have the authority to control the extraction rate (IEA 1992c).

The development of domestic oil resources is prohibited in the ANWR, the Alaskan North Slope, and parts of the OCS (EAI 1992b). The Federal Government (through the U.S. Department of Treasury) has the right to review investments when foreign ownership exceeds $5 \%$ (IEA 1992c).

Distribution Restrictions: Oil moving from one U.S. port to another must be carried on U.S. built and - flagged ships with U.S. crews as required under the Jones Act (Merchant Marine Act of 1920, 46 U.S.C. $\S 833$ et seq.). Tariffs on common carriers of crude oil have to be approved by the Federal Energy Regulatory Commission (FERC) (IEA 1992c).

The EPACT required that FERC reform oil pipeline regulations to improve efficiency, increase competition, and reduce the regulatory burden (IEA 1993a).

Trade Policies: Exports are prohibited for oil transported through the TransAlaska Pipeline, except 50,000 bd which may be exported to Canada under the U.S.-Canada Free Trade Agreement (CFTA). The North American Free Trade Agreement (NAFTA) reaffirms CFTA language (USITC 1993). There are no import restrictions on oil imports. The import duty in crude oil averages about $0.5 \%$ ad valorem for crude oil. This duty has been eliminated for imports from Canada and will be eliminated for Mexico over a 10-year period (USITC 1993). Export licenses are required to export crude oil from the continental United States, but they are readily granted (IEA 1992c).

Price Controls: There are no price controls on crude oil in the United States (IEA 1992c). 
Direct Subsidies: There are no direct subsidies for crude oil production (IEA 1992c). The EPACT provided tax relief for independent oil and gas drillers under the Alternative Minimum Tax (IEA 1993a).

Government-Sponsored R\&D: In FY 1992, about \$58 million was allocated for oil-related research and development, aimed primarily at research on enhanced oil recovery. Some of the research was also directed at liquefaction of oil shale (EAI 1992b). Enhanced-recovery R\&D appropriations jumped to \$75 million in FY 1994 and the Clinton Administration asked for \$104 million for FY 1995 (Knott 1994b).

The EPACT provided for joint federal-private research and development and demonstration projects aimed at increasing domestic oil recoverability by 20-65 billion barrels by 2010 and for income tax credits for companies that paid into the TransAlaska Pipeline (IEA 1993a).

Taxes: Corporations pay the Federal corporate tax rate on their earnings. There is a depletion allowance. Oil extracted from Federal lands is subject to a royalty of $12.5 \%$ if the site is in deep water, and $16.5 \%$ elsewhere. There is usually some kind of lease payment on Federal land and States usually impose some kind of severance tax (IEA 1992c). The royalty rate for stripper wells on Federal lands is reduced from $12.5 \%$ to as low as $0.5 \%$ on a graduated scale for each well as production declines. Overall production is estimated to increase by up to $13,000 \mathrm{bd}$ as a result of this move (IEA 1993a).

\section{Refined Oil}

Background: In the beginning of 1991, foreign affiliates owned $28 \%$ of the total U.S. oil refinery capacity (DOE 1993). Canada and Mexico are major U.S. trading partners in refined oil products.

Government Ownership of Business Entities: Production of refined oil products occurs in the private sector (IEA 1992c).

Investment and Production Restrictions: If foreign ownership exceeds 5\%, the Treasury can initiate a review (IEA 1992c).

Distribution Restrictions: None.

Trade Policies: Products from oil transported in the TransAlaska Pipeline are not allowed to be exported, but all other products, if licensed, are allowed. Licenses are readily available (IEA 1992c). There are no nontariff import controls on refined oil products, only tariffs: 10.5 cents per barrel for 
naphtha, diesel, and heavy oils; 52.5 cents per barrel for gasoline; and 84 cents per barrel for lubricants (IEA 1992c). The ad valorem equivalent of these duties is about 1\%. Imports from Canada are currently duty-free. The duties on imports from Mexico will be phased out over 10 years (USITC 1993).

Price Controls: There are no price controls on refined oil products (IEA 1992c).

Subsidies: There are no subsidies on refined oil products (IEA 1992c).

Taxes: Automotive fuels are subject to State and Federal taxes and State sales taxes. Household fuel oil and liquid propane gas (LPG) are subject to State and local taxes. No other oil product has consumer taxes (IEA 1992c).

Other Policies: There are some Federal regulations on sulfur content of diesel fuels $(0.05 \%)$ and on oxygenated gasoline (2.7\%) for 44 major U.S. cities (IEA 1993a).

\section{Natural Gas}

Background: About 10,000 small producers and the major oil companies provide the United States with all but $7 \%$ of its natural gas supplies. About 100 large companies are responsible for distributing $95 \%$ of the natural gas sold (IEA 1992c).

The United States imports about 10\% of its gas from Canada (IEA 1993a). Gas exports to Mexico have been increasing (USITC 1993), but they only represent about $0.5 \%$ of the U.S. production in 1992. The U.S. exported nearly 50 billion cubic feet of natural gas to Mexico in 1992 (Farmer 1993b).

Government Ownership of Business Entities: Business ownership for development and exploration of natural gas deposits is the same as for crude oil deposits (IEA 1992c).

Government Ownership of Natural Resources: Ownership of natural gas deposits is the same as for crude oil deposits (IEA 1992c).

Investment and Production Restrictions: Texas and Louisiana are considering "prorationing" of gas. This may not be consistent with Federal Law (IEA 1992c). Foreign investment shares over $5 \%$ may be reviewed by the U.S. Government (IEA 1992c).

Distribution Restrictions: The FERC Order 636 is a set of rules and guidelines covering the operation and transmission of interstate gas business. The Order requires changes in U.S. natural gas operations including open access to transportation and storage; the unbundling of pipeline services, i.e., gas 
supply, transportation, storage, and backup; capacity reallocation; and a new rate structure which mandates a "straight fixed variable" rate design. The 1991 FERC Rule governing natural gas pipeline construction is aimed at expediting construction approval and placing more reliance on the market to price new pipeline services (IEA 1993a).

Trade Policies: Under the EPACT, the DOE's process for authorizing natural gas imports and exports is expedited for countries with which the United States has free trade agreements and for liquefied natural gas (LNG) imports (IEA 1993a). There are no import duties on natural gas. Natural gas imports and exports, however, are controlled by the Federal Government, but the NES recommended discontinuance of regulations concerning the import and export of natural gas (IEA 1992c).

Price Controls: Local suppliers are usually monopolies controlled by State Public Utility Commissions. Retail prices are usually determined by State public utility commissions based on a rate of return. Well-head prices have been decontrolled (IEA 1992c).

Subsidies: The EPACT provided for tax relief for independent oil and gas drillers under the Alternative Minimum Tax. The changes in the tax are intended to improve profitability and reinvestment and will cost the Federal government about $\$ 1$ billion (foregone revenue) over the next 5 years (IEA 1993a).

Government-Sponsored R\&D: The U.S. Government spent about \$21 million spent in 1992 (EAI 1992b).

Taxes: Companies are subject to corporate taxes on profits subject to depletion allowances. There are no subsidies (IEA 1992c).

Other Policies: The EPACT provides tax incentives for purchasing alternative fuel vehicles as well as for fueling facilities (Rozenzweig 1993). In addition, the alternative fuel program is expected to lead to greater use of compressed natural gas (CNG) as a transport fuel (IEA 1993a). The EPACT also reduces tax subsidies for car transportation such as employer subsidized parking and provides subsidies for the use of mass transit or carpooling (Rozenzweig 1993).

Prior to the EPACT, the Alternative Motor Fuels Act of 1988 and the Clean Air Act Amendments of 1990 encouraged the use of alternative fuels as a means of reaching the policy goal of reducing heavy reliance on oil in transportation. These provisions call for State and Federal government fleets to contain a certain percentage of alternative fuel vehicles. They set goals for private fleets and municipal governments as well (OECD 1992; EAI 1992a). 


\section{Coal}

Government Ownership of Business Entities: About $60 \%$ of U.S. mines are controlled by gas or petroleum companies (40\%), steel companies (15\%), and electric utilities (5\%) (IEA 1992c).

Government Ownership of Natural Resources: As with crude oil, ownership belongs to the owner of the land. About 33\% of U.S. coal resources are under Federal Land (IEA 1992c).

Investment and Production Restrictions: Surface coal mining is partly regulated by the Surface Mining Control and Reclamation Act. Licensees must put up a bond to ensure that land is reclaimed after the open mining has been completed. States are the main regulators of mining, but the Department of Interior is the regulatory authority on Federal land (IEA 1992c). Foreign investment shares over 5\% may be reviewed by the U.S. government (IEA 1992c).

Distribution Restrictions: The Jones Act applies to the movement of coal between U.S. ports as well as to petroleum. There are no other distribution restrictions.

Trade Policies: There are no controls or duties on exports or imports. The government does have bilateral agreements with other countries for coal sales (IEA 1992c).

Price Controls: The Staggers Rail Act of 1980 provides rate protection to captured entities such as coal mines. There are no price controls on coal (IEA 1992c).

Subsidies: There are no direct subsidies (IEA 1992c).

Government-Sponsored $R \& D$ : The NES's strategy for coal has centered on maintaining the fuel's competitiveness both domestically and for export while seeking to develop new technology permitting coal to be used in an environmentally acceptable manner. The main government initiatives continue to be the Clean Coal Technology Demonstration Program, a multibillion dollar project with joint federal and industry funding; and R\&D for superclean, high-efficiency technology and liquid fuels (IEA 1993a).

Government R\&D appropriations for coal in FY 1993 declined by $\$ 80$ million dollars from $\$ 789$ million in FY 1991. The clean coal technology program accounts for the largest share of government R\&D spending. The major areas being cut are preparation, mining, and coal conversion. Appropriations for the clean coal technology program are far greater than the outlays (68\% unspent) (EAI 1992b).

Taxes: Coal production is taxed like all other company profits. There is an $8 \%$ depletion allowance. In addition, most States have a severance fee on production. There are also taxes to provide for disabled miners from pneumoconiosis and a reclamation fee to reclaim abandoned mine land. Coal on Federal land is subject to an $8 \%$ royalty on underground mines and a $12.5 \%$ fee on surface mines. There are no sales taxes on the consumption of coal (IEA 1992c). 
Other Polices: The United States has relatively high Environmental, Health, and Safety costs when compared with other major exporting countries such as Australia, Canada, Columbia, and South Africa. Compared with Australia, South Africa, and Canada, the United States has higher regulatory costs. Mine mouth costs for the United States are usually lower than those for Australia or Canada. Transportation costs, and environmental, health and safety costs are often the deciding factor in determining the lowest cost per ton of delivered coal (DOI 1993).

\section{Nuclear}

Background: Besides the DOE, the Nuclear Regulatory Commission is responsible for licensing nuclear power facilities. In the early 1990s, nuclear power accounted for almost $20 \%$ of the electricity generated in the United States (Rozenzweig 1993); it accounts for only $9 \%$ of total energy used today (IEA 1993a). While nuclear power plants are being decommissioned, there are few replacements being planned because of regulatory and planning problems (IEA 1992a).

Government Ownership of Business Entities: The Nuclear Regulatory Commission (NRC) is responsible for regulation of nuclear power in the U.S. Many of the activities occur in the private sector but there is much oversight because of defense and safety considerations (IEA 1992c).

Government Ownership of Natural Resources: Uranium mining and milling is in the private sector. The NRC is responsible for licensing transfers of uranium. Small quantities are exempt. The Department of Energy, through subcontractors, is responsible for enriching nuclear materials (IEA 1992c).

Production Restrictions: In the EPACT, nuclear plant licensing procedures were changed to allow a combined construction and operating license to be issued to help avoid procedural delays and higher costs associated with the former post-construction hearing process. Any further nuclear power plant construction, however, will most likely depend on a solution to the waste disposal problem and the certification of new reactor designs now being developed (IEA 1993a; Rozenzweig 1993).

In addition, the EPA is also responsible for authorizing plant location and setting pollution discharge limits. States can also get involved in the sitting process and waste site storage placement. States are also responsible for safe storage and deposition of low and intermediate level nuclear waste (IEA 1992c). Foreign ownership is prohibited (IEA 1992c).

Taxes: Private nuclear power facilities are taxed like any electric utility company (IEA 1992c).

Government-Sponsored $R \& D$ : Total government R\&D of nuclear power is projected to increase from $\$ 771$ million in 1991 to over $\$ 1$ billion. The heaviest focus is on waste, fuel, and safety, which are receiving well over half of the budget (EAI 1992b). 


\section{Electricity}

Background: The United States is a net importer of electricity from Canada and a net exporter to Mexico (USITC 1993).

Government Ownership of Business Entities: Most facilities are privately owned. Investor-owned utilities accounted for almost $75 \%$ of U.S.-installed generating capacity and mainly sell directly to retail customers. Non-utility generators account for about $6 \%$ of the installed U.S. capacity; the remaining capacity is owned by federal, state, or local government and cooperatives. Six federal power marketing authorities account for about $8 \%$ of the U.S. capacity and generation. Municipal, state, and county utilities have slightly more capacity (10\%) than generation $(8.5 \%)$. Rural cooperatives account for about $5 \%$ of the generation and capacity (IEA 1992c).

Investment and Production Restrictions: Utilities that operate in more than one state are subject to regulation by the Securities Exchange Commission. Utilities are also subject to FERC regulations (IEA 1992c).

Plant sitting is subject to State Utility Commission authority. Building a hydroelectric plant on a navigable river requires a Federal permit. Several agencies are responsible for authorizing the permit, with FERC in the lead (IEA 1992c).

The Public Utilities and Regulatory Policies Act of 1978 (PURPA) (16 U.S.C. $\$ \S 2601-2645$ ) requires utilities to buy electricity from small power generation and cogeneration plants without being subject to rate regulation (IEA 1993a).

The EPACT reformed the PUHCA to allow broader competition in wholesale electricity (IEA 1993a; Rozenweig 1993). The amendment allows independent suppliers of electricity easier access to supplying incremental energy while not being subject to the constraints of the PUHCA (Rozenzweig 1993).

The legislation also amended Section 211 of the Federal Power Act (16 U.S.C. $§ 791$ et seq.) and allowed the FERC to order transmission of wholesaler electricity subject to certain stipulations regarding whether it is in the public interest and does not affect the reliability of the electrical system. These changes are expected to save the U.S. economy $\$ 250$ billion by 2010 (Rozenzweig 1993). The EPACT removed barriers to ownership by U.S. companies of facilities abroad. The Treasury has the right to review foreign investments in the United States when foreign ownership exceeds $5 \%$ (IEA 1992c).

Distribution Restrictions: Local suppliers are usually monopolies controlled by state regulated utility commissions (IEA 1992c).

Trade Policies: Licenses for exporting and importing electricity are largely a formality. There are no import duties. Theoretically, state utility commissions can control imports (IEA 1992c). 
Price Controls: Retail prices are usually determined by State public utility commissions based on a rate of return (IEA 1992c).

Subsidies: There is some subsidization of the electricity. Rural Cooperatives usually receive favorable rates on Federal funding. In addition, Federal Marketing Administrations are allowed to sell electricity at rates below full cost and utilities can get subsidized interest rates on loans (IEA 1992c). Some portion of the subsidy received by consumers of electricity from the Power Marketing Administrations is because they sell the energy at cost rather than at what the market would bear (EAI 1992b).

Government-Sponsored R\&D: The government spent $\$ 5$ million on R\&D of electricity in 1992 (EAI 1992b).

Taxes: States usually apply sales taxes of 2 to $6 \%$ (IEA 1992c).

\section{Renewable Energy}

Subsidies: In the EPACT, a tax credit of 1.5 cents per kilowatt hour for electricity produced from new wind installations and certain types of biomass facilities was given and a investment tax credit for solar and geothermal plants was given a permanent extension. Extension of the tax credit qualifying periods on non-conventional fuels such as gas from biomass and synfuels from coal were extended (IEA 1993a).

Government-Sponsored $R \& D$ : A five-year demonstration and commercialization program was instituted to accelerate commercial application of renewable supply and energy efficiency technology. A five-year program to develop cost-effective power generation from renewables was instituted (IEA 1993a).

Appropriations for renewable energy R\&D were projected to rise from $\$ 200$ million in FY 1991 to $\$ 250$ million in FY 1993. The largest increase (\$60 million) was in photovoltaic research. Geothermal, hydroelectric, and electricity technologies remained unchanged for the most part. Biofuels technologies decreased by more than $\$ 10$ million dollars (EAI 1992b). 


\title{
Australia
}

\begin{abstract}
All Sectors
Background: Australia is the largest world exporter of coal and a major exporter of uranium (IEA 1992c).
\end{abstract}

Energy Supply: In 1989-90, coal supplied $41 \%$ of Australia's energy demand; oil, 37\%; and gas, $17 \%$ (IEA 1992c).

Trade: Energy exports accounted for about $22 \%$ of Australia's export income in 1989-90 and was also a major revenue source for the Government.

Policies: Energy policy is divided between the States and the Commonwealth. Primary responsibility is with the Department of Primary Industries and Energy. Policies regarding the development of energy within their borders belong to the state and territorial governments (IEA 1992c).

The Commonwealth's stated primary role is that of leadership in promoting cooperation on infrastructure, standards, industry organization, and pricing. Australia's energy policy promotes efficiency of production and distribution and use through market forces. Only market failures provide a need for government intervention (IEA 1993a).

The key issues for Australian energy policy in 1992 were providing a coordinated energy policy for Australia, drawing up a national strategy for the rational development of natural gas, maintaining energy supplies for Australia, and enhancing Australia's position as a reliable supplier of a diversified mix of clean fuels (IEA 1993a).

Energy and the Environment: The Government adopted a goal of stabilizing greenhouse gas emissions by the year 2000 (at 1988 levels) and reducing them by $20 \%$ by 2005 . They have stated, however, that they will not do anything that jeopardizes the economy (IEA 1992c).

Australian industry spent about US\$2 billion on environmental equipment in 1990 . Expectations are that it will spend about US $\$ 2.8$ billion by 2000 on environmental equipment, about a $4.4 \%$ annual increase in expenditures. In 1990, Australian expenditures as a share of the GDP were about $0.67 \%$, and about US\$117 per capita (IEA 1992c), ${ }^{\text {(a) }}$

Other Policies: In general, the Commonwealth Government of Australia uses a work program bidding system to lease oil and gas sites (IEA 1992c).

(a) Organization for Economic Co-operation and Development, "Environmental Cost and Industrial Competitiveness." OECD, Paris, France. Restricted document, draft, 5/20/92. 
Australia has a bilateral agreement with Algeria to promote growth in the energy sectors (GATT 1993a).

Subsidies: The Commonwealth also has an Export Market Development Scheme. This scheme reimburses certain upfront costs such as travel and promotional expenditures. It is primarily aimed to help small firms. Reimbursements are subject to a maximum export income of A $\$ 20$ million and cover $70 \%$ of expenses over $\mathrm{A} \$ 10,000$, up to a total of a $\mathrm{A} \$ 200,000$. Grants are reduced over time (GATT 1993a).

Government-Sponsored R\&D: In 1989-90, Australian Government R\&D expenditures were $0.031 \%$ of the GDP (IEA 1992c). During 1978-90, the National Energy Research, Development, and Demonstration program was the principal government sponsor of energy $R \& D$, spending more than A $\$ 270$ million.

The government provides energy R\&D assistance through grants and funding of government research institutes (IEA 1993a). The government provides direct funding (usually requiring matching) and indirect government assistance through tax incentives (IEA 1993a). In addition, the government provides internal funding within organizations such as universities, the Commonwealth Scientific and Industrial Research Organization (CSIRO), and the Bureau of Mineral Resources (IEA 1992c).

In an effort to link R\&D with commercial applications, the Government introduced mechanisms to enhance industry involvement, including establishing the Energy Research and Development Corporation (ERDC), (a quasi-governmental R\&D corporation), an industry-managed coal R\&D program, and a $150 \%$ tax deduction for R\&D expenditures (IEA 1993a).

\section{Crude Oil}

Background: Australia is $85 \%$ self-sufficient in crude oil. Five oil companies, with various degrees of foreign ownership, own Australia's eight fuel refineries and four lubricating oil refineries (IEA 1993a).

Government Ownership of Business Entities: Ownership is in the private sector (IEA 1992c).

Government Ownership of Natural Resources: The States and Territories own the oil reserves within their boundaries and out to the three-nautical-mile limit offshore. The Commonwealth owns everything beyond the three-nautical-mile line. This area constitutes the bulk of Australia's oil reserves (IEA 1992c).

Investment and Production Restrictions: Exploration rights are granted based on permits awarded on a bidding system (IEA 1992c). Foreign companies may explore for crude oil. Exploration investments of more than A $\$ 10$ million are subject to Commonwealth Government scrutiny. Requests are granted unless they are not considered to be in the national interest (IEA 1992c). 
Trade Policies: There are no import or export controls, nor are there any import duties on crude oil. There could be export controls during a state of emergency. The Commonwealth has the power to direct slower or more rapid extraction within a particular area (IEA 1992c).

Price Controls: Since January 1, 1988, crude oil and refined oil producers may freely negotiate for prices. The Government no longer determines the maximum wholesale price for crude oil (IEA 1992c).

Subsidies: There are no subsidies on crude oil (IEA 1992c).

Government-Sponsored $R \& D$ : Crude oil R\&D is $150 \%$ tax deductible for firms. General Agreement on Tariffs and Trade (GATT) documents indicate that the tax deductible for R\&D was to be $125 \%$ between June 1993 and June 1995, after which it would drop to $100 \%$. Later documents make no mention of these changes taking place. Prior to June 1993, the R\&D tax deduction was 150\% (GATT 1993a; IEA 1992c, 1993a).

Taxes: Taxes vary between the Commonwealth, State, and Territorial governments, as well as by extraction site. Areas other than the North West Shelf have a Resource Rent Tax (RRT) of $40 \%$ on the excess of net assessable receipts. Other areas under Commonwealth jurisdiction pay a royalty which amounts to $10-12.5 \%$ of wellhead value. State governments also impose a royalty on production within their regions. The Commonwealth government also has an excise tax, with the first $\mathbf{3 0}$ million barrels from any one field being exempt from the tax (IEA 1992c). In 1990, the Commonwealth Government announced a package of reforms for oil companies to encourage exploration efforts in frontier areas (IEA 1993a).

\section{Refined Oil}

Background: In 1987, fuels represented a $21 \%$ share of the US\$25.4 billion of Australian exports and a $5 \%$ share of US $\$ 26.9$ billion of imports (GATT 1993a).

Government Ownership of Business Entities: Ownership and control of refineries and distribution of products is in the private sector (IEA 1992c, 1993a).

Trade Policies: There are no controls on imports, exports, or transport of refined oil products. However, an excise tax equal to that paid by indigenous producers is placed on all imported refined products (IEA 1993a). In July 1989, the simple average of tariffs applied to products refined from petroleum, gas, or coal was $3.3 \%$ ad valorem with a range of $0-17.5 \%$ ad valorem (GATT 1993a).

Price Controls: The Price Surveillance Authority sets ceilings on wholesale gasoline and petroleum distillates prices. However, retail outlets compete for business (IEA 1993a). 
Subsidies: For producers in remote areas of Australia, the Petroleum Products Freight Subsidy Scheme lowers the costs of petroleum products. This subsidy only applies to remote areas of the Northern Territory, Queensland, and Western Australia (IEA 1992c).

Taxes: Both the commonwealth and state governments place excise taxes and fees on refined products (IEA 1992c, 1993a). With the exception of Queensland, which doesn't tax gasoline and diesel, the franchise licensing fee is 5.5-7.45 cents/litre (IEA 1993a). Diesel, gasoline, kerosene, aviation gasoline, heating oil, and fuel oil are taxed. Some primary producers using diesel for off-road purposes can receive an excise tax rebate (IEA 1992c). Shale oil gasoline products from some specific demonstration plants will be exempt from excise taxes until 2005 (IEA 1993a).

\section{Natural Gas}

Background: In Australia, LNG is a major export commodity (IEA 1992c). In 1992, the LNG exports totaled A $\$ 880$ million or $8 \%$ of Australia's energy exports. Australia is a net energy exporter (IEA 1993a).

Government Ownership of Business Entities: Private production of natural gas is encouraged (IEA 1992c).

Government Ownership of Natural Resources: Ownership of natural gas resources is the same as that of crude oil (IEA 1992c).

Investment and Production Restrictions: Foreign investments greater than A\$10 million are subject to government scrutiny (IEA 1992c).

Distribution Restrictions: Utilities are owned by the states, but distribution of gas is divided between private ownership and state-owned distributors (IEA 1992c). Distributors have a monopoly in their distribution area. Direct sales are allowed, but in practice are limited to a large industrial users (IEA 1993a).

In 1992, the Commonwealth Government announced that it would sell the Moomba-Sydney pipeline, which was owned and operated by The Pipeline Authority (TPA) (IEA 1993a). A second interstate pipeline, from Southwest Queensland to Moomba in southern Australia, was scheduled to become operational in January 1994. Third party access provisions vary by state (IEA 1993a).

Trade Policies: There are no restrictions on imports or import duties on natural gas. The government oversees pricing of LNG. The government is seeking to avoid transfer pricing and to ensure that adequate prices are received (IEA 1992c).

Price Controls: Gas prices are negotiated between the producers and the distributors. The state utilities have considerable authority over how prices are administered. 
Subsidies: There are cross subsidies in natural gas pricing. These subsidies will be reduced or made more transparent. Pensioners, large users, and remote areas receive concessions on price (IEA 1992c).

Taxes: While there is no Commonwealth tax on natural gas, producers do pay an RRT. (A royalty of $10-12.5 \%$ of wellhead value is applied in the North West Shelf area.) In addition some states include a tax on consumption. In Victoria, the gas supply utility pays one-third of its revenue to the state. Large users also pay a levy (IEA 1992c).

\section{Coal}

Background: The Australian coal industry is considered among the most efficient in the world (IEA 1993a). Coal accounted for $62.4 \%$ of all energy exports in 1990-91 (A $\$ 6.8$ billion). In 1991, Australia exported over 120 million metric tons of coal, accounting for $32 \%$ of the seaborne trade in coal (IEA 1993a).

Australian mining costs are generally higher than U.S. costs. But Australian delivered costs are usually less than U.S. costs because of lower transportation and regulatory costs. For example, Australian transportation costs to Japan are less than the lowest U.S. transportation cost to Japan. Australia has a distinct transportation advantage of about $\$ 7$ per short ton (st) over both Canada and the United States (DOI 1993).

Australian coal mines usually have lower regulatory implementation costs (health, safety, and environment) than U.S. coal mines. In longwall-method coal mining, the level of total Australian regulatory costs are in the same range, but less than U.S. costs. Black lung and land reclamation account for $0.3 \%$ of Australia's longwall costs, compared with 6 to $9 \%$ of U.S. costs. Australia's environmental regulatory costs for this type of mine range from 5 to $52 \%$ of the level of U.S. costs (DOI 1993).

In large continuous miner method mining, Australia has no environmental regulatory costs, compared with \$0.10-\$0.24 per st for U.S. environmental mine costs. In comparable surface mining methods, Australian regulatory costs are 24 to $51 \%$ of the level of comparable U.S. costs. The environmental portion of the regulatory costs is 6 to $41 \%$ of the level of U.S. costs for surface mines (DOI 1993).

Government Ownership of Business Entities: Business entities in the coal sector are owned by both private companies and public utilities. Companies lease mining rights from the states (IEA 1992c).

Government Ownership of Natural Resources: State governments own the coal reserves in their states and are responsible for leasing the deposits and imposing conditions regarding safety, environmental protection, royalties, transport, and other issues (IEA 1993a). 
Investment and Production Restrictions: There is no limit on foreign investment during the exploration phase. Once production begins, the Australian Government, through the Foreign Investment Review Board, monitors investment levels. All new mines with a A\$10 million investment value must have $50 \%$ Australian ownership. Existing mines may be allowed to continue with $100 \%$ foreign ownership (IEA 1992c).

Trade Policies: The government has controlled coal exports since 1973. The government does not negotiate coal prices, but Australian coal exporters are required to submit export settlements to the government for approval. The government generally approves settlements quickly and rejects settlement only where it decides that compelling national interest considerations are involved (GATT 1993a; IEA 1992c, 1993a). Export duties were removed in 1992 (IEA 1992c).

Price Controls: Some coal mines are designated to provide coal to the electricity, iron, and steel industries, but there is no guaranteed market. However, the Queensland Coal Board oversees the allocation of coal and controls the price, especially to small consumers. Major buyers can enter into private contracts with approval from the board (IEA 1992c).

The industry has remained competitive through restructuring (closing inefficient mines--1500 hard coal mining jobs have been lost since the beginning of 1992), increased mechanization, restructuring of performance award programs, and reduced charges for infrastructure services, along with productivity increases (IEA 1993a).

Subsidies: There are no subsidies in the coal industry according to the OECD International Energy Agency (IEA 1992c). According to John Rasmussen, an official with the U.S. Department of Commerce, there may be subsidized transportation of Australian coal, but no one has ever substantiated it. $^{\text {(a) }}$

The Commonwealth Government is actively involved in, and funds, specific coal trade promotion activities (IEA 1993a). The Queensland Coal Board provides long range planning and overview to mines in that state. The board also implements the Commonwealth industry policy (occupational health, rehabilitation, workers' compensation and miner training.) The Joint Coal Board, a joint state and Commonwealth board, oversees the industry (IEA 1992c).

Government-Sponsored $R \& D$ : Levies on coal by the Commonwealth are used in part for coal industry R\&D. This function is being transferred to the industry (IEA 1992c). Coal R\&D is $150 \%$ tax deductible for firms (IEA 1993a).

Taxes: Commonwealth excise taxes are levied on black coal. The proceeds go to the Long Service Leave Fund. Payroll-based and industry levies will replace the excise taxes as the fund is reorganized. Two states also place royalties, payroll taxes, and other charges on coal (IEA 1992c).

(a) Personal communications with John Rasmussen, International Trade Administration, Energy Office, Trade Specialist, Department of Commerce, 3/22/94. 


\section{Nuclear}

Background: Australia has decided to exclude nuclear energy from its energy mix. But the country is a major exporter of uranium. There is no nuclear energy program in Australia (IEA 1992c).

Government Ownership of Natural Resources: There is some foreign ownership of the mines. The Ranger Mine has $25 \%$ foreign ownership and the Olympic Dam is owned jointly by Western Mining Corporation and Australian BP (IEA 1992c). No statements were found on ownership of mineral rights.

Australia has restricted mining to three mines. One is closed. Uranium is only exported to countries which have a bilateral nuclear safeguards agreement with Australia (IEA 1992c).

Price Controls: The government oversees the pricing of uranium exports to ensure that adequate prices are being received (IEA 1992c).

\section{Electricity}

Government Ownership of Business Entities: The state governments own the electricity supply. The Commonwealth is involved in the Snowy Mountain hydroelectric projects and in the supply of electricity to the Capital Territories. The Commonwealth also acts as a liaison between state governments on electricity matters (IEA 1992c).

Some states are contemplating private electricity power generation. A 600 megawatt (MW) privately owned coal-fired plant has been approved for construction in Western Australia (IEA 1992c).

Investment and Production Restrictions: Electricity transmission is owned by the state governments (IEA 1992c). In May 1991, Australia recommended separating the ownership of generation, transmission, and distribution facilities to make generation more competitive (IEA 1992c). In addition, plans are underway to transfer ownership of a major power facility to the private sector (IEA 1993a).

Distribution Restrictions: In December 1992, the Commonwealth and the States came to an agreement to complete one integrated electrical transmission grid (IEA 1993a).

Price Controls: Prices are set by state commissions with the approval of the state governments (IEA 1992c, 1993a).

Subsidies: Subsidies are provided to large users, pensioners, and consumers in certain remote areas. Currently, there are cross subsidies between rural and urban consumers. These subsidies will either be made transparent or reduced in the future (IEA 1992c).

Taxes: There are no direct taxes on consumers for electricity (IEA 1992c). 


\section{Renewable Energy}

Background: Australia is the largest commercial user of photovoltaic cells in the world. These cells usually serve remote telecommunication installations. Solar water heaters supply $5 \%$ of Australia's hot water demand (IEA 1993a).

Subsidies: Cross-subsidies to remote users in the electricity market serve as barriers to further development of solar power (IEA 1993a). The State of Victoria has provided incentives for cogeneration and renewable resources generation (IEA 1992c). By the end of 1992, 14 projects were online and a target of $220 \mathrm{MW}$ has been set for 1995 (IEA 1993a).

Government-Sponsored $R \& D$ : The Government provides R\&D for renewable energies and exempts equipment used in developing renewable energy production from sales tax. The states also support renewable energy. A 10-MW wind generation farm is being sought by the State of Victoria. Harnessing landfill gas and sea wave energy are two projects being undertaken by governments in Western Australia and Tasmania (IEA 1992c). 


\section{Canada}

\section{All Sectors}

Background: Canada is self-sufficient in energy.

Energy Supply: Canada's TPES in 1991 came mainly from oil (34.5\%), natural gas (26.4\%), hydro/ geothermal $(12.4 \%)$, and coal $(12 \%)$. Nuclear energy provided $10.4 \%$ of the energy supply and other solid fuels contributed $4.1 \%$ (IEA 1993a).

Trade: Canada is a net exporter of coal, oil, gas, and electricity. However, due to geography and politics, the eastern provinces import oil and don't have access to natural gas (IEA 1992c).

General Policies: Policy is determined and set forth by the Federal government, but provincial governments can impose stricter laws and regulations (IEA 1992c). The NAFTA is not binding on provincial laws.

The Canadian Government has pursued a market-oriented energy policy to promote investment and to enhance competitiveness and efficiency of the energy sector. Foreign ownership restrictions in upstream oil and natural gas industry were revised in 1992 (IEA 1993a).

Government Ownership of Business Entities: The 1989 CFTA specifically excluded gas and oil industries from a $50 \%$ Canadian ownership requirement for exploration and exploitation companies (IEA 1992b).

Government Ownership of Natural Resources: The provinces own natural resources within their borders. The ownership of offshore resources is disputed between provinces and the Federal government (IEA 1992c).

Energy and the Environment: Canada is a signatory of the 1992 Framework on Climate Change. There is a program developed to achieve the emission cap (IEA 1993a).

In 1990, Canadian industry spent about $1.2 \%$ of its GDP and US\$270 per capita on environmental equipment and protection. (a) Canadian industry spent about US\$7 billion in 1990 on environmental equipment and protection. The OECD expects sales to grow at $7.9 \%$ annually to about US\$12 billion in the year 2000 (OECD 1992).

(a) Organization for Economic Co-operation and Development (OECD). "Environmental Cost and Industrial Competitiveness." OECD, Paris, France. Restricted document, draft, 5/20/92. 
Government-Sponsored $R \& D$ : In 1991, total R\&D expenditures in Canada were divided between industry $(56.8 \%)$, the Federal Government $(36 \%)$ and the provincial governments $(7.2 \%)$. The Canadian Government spent $0.053 \%$ of its GDP on energy R\&D in 1991. Nuclear research accounted for $67 \%$ of Government R\&D in 1991-92. Another 10\% was spent on energy efficiency and fusion research. There is extensive collaboration between Federal and provincial research laboratories (IEA 1993a).

The Panel on Energy Research and Development (PERD) coordinates non-nuclear and fusion research activities. In 1991, PERD funding for oil, electricity, and gas was C\$18 million (6\% of the government R\&D); energy efficiency, $C \$ 14.8$ million (5\%); nuclear fusion research, $C \$ 12.8$ million (4\%); hydrocarbon enhancement, bitumen and heavy oil, $\mathrm{C} \$ 12.7,(4 \%)$; renewable energy sources and the environment, $\mathrm{C} \$ 10.8(4 \%)$; clean coal technology, $\mathrm{C} \$ 10.2(4 \%)$; and alternative transport fuels, $\mathrm{C} \$ 8.6$ (3\%) (IEA 1993a).

\section{Crude Oil}

Background: Canada's Atlantic provinces import oil while its western provinces export oil. Development by the federal government of the Hibernia field off the coast of Newfoundland may reduce eastcoast imports (IEA 1993a).

Canada exported 136,000 cubic meters of oil per day in 1992, which was about $50 \%$ of Canadian production (IEA 1993a). Most of the oil goes to the United States (IEA 1992b). A considerable amount of U.S.-Canada trade in oil and refined oil products is from companies with plants on both sides of the border moving feedstocks and raw product back and forth. Imports of crude oil are exchanged for exports of refined products to the United States (USITC 1993).

Government Ownership of Business Entities: Concessions are granted by the government to private and state-owned companies, both national and international. Canada's state-owned company Petro-Canada is being privatized (IEA 1992c). In early 1994, approximately $70 \%$ of Petro-Canada was still held by the government. ${ }^{(a)}$

The Canadian government owns $8.5 \%$ of the Hibernia oil field project, and if a second member of the consortium backs out, the government will buy an additional 6.5\% (IEA 1993a). Mobil-Canada has a $33.125 \%$ share in the Hibernia Project; Chevron-Canada, 26.875\%; Murphy Oil (an Arkansas firm), $6.5 \%$; and Petro-Canada, a $25 \%$ share. $^{(b)}$

(a) Personal communications with Jim Campbell, Director of Economic Analysis, Energy Policy Branch, Natural Resources Canada, 3/29/94.

(b) Personal communications with Susan McLaughlin, Monitoring Unit, Economic and Financial Analysis, Natural Resources Canada, 3/30/94. 
Government Ownership of Natural Resources: On provincial lands, natural resources are owned by the provincial government. Ownership of offshore lands are under dispute between provinces and the federal government (IEA 1992c).

Investment and Production Restrictions: Production is regulated by the provinces. Some of the regulation is to ensure that companies are run efficiently and in an environmentally safe manner. In Alberta, removal of oil and gas resources is allowed only if the provincial government believes it is in the longterm interest of Alberta. The National Energy Board oversees the interprovincial and international movement of oil through pipelines.

Foreign investment is subject to threshold levels of review of C $\$ 150$ million for U.S. investors. For other nationalities, the level is $\mathrm{C} \$ 5$ million for direct acquisitions and $\mathrm{C} \$ 50$ million for indirect acquisitions (IEA 1992c).

Under NAFTA, Canada added specific investment requirements associated with the Hibernia Project off Newfoundland, and in the Northwest and Yukon Territories. The accords specifically state the local content for subcontracting and technology transfer requirements for foreign investors (Farmer 1993a).

Trade Policies: There are no landing requirements or import restrictions. Transportation of crude oil by tanker is regulated by the Canada Shipping Act (IEA 1992c). Import duties, which average $0.5 \%$ ad valorem will be eliminated for the United States and Mexico within a 10-year period. The National Energy Board licenses exports (IEA 1992c). Under the CFTA, there are no meaningful restrictions on trade between Canada and the United States (USITC 1993).

Price Controls: There are no price controls (IEA 1992c).

Subsidies: Direct investment assistance is available for megaprojects. The assistance can include capital grants, tax concessions, concessional interest rates, low interest loans, or tax holidays. In Alberta, the tax holiday can amount to up to $\mathrm{C} \$ 1$ million per exploration well during the first two years (IEA 1992c).

In 1990 , four companies, working as a consortium, were offered $\mathbf{C} \$ 2.7$ billion in assistance from the federal government to develop the Hibernia oil field off Newfoundland (IEA 1993a), representing over half of the original C\$5 billion estimated cost (IEA 1992b). Chevron is one of the three remaining companies working the Hibernia field (Koen and True 1994a).

Taxes: Oil is subject to provincial royalties. These will vary depending on the date of discovery, quality of the crude, and other criteria (IEA 1992c). There is no depletion allowance, but firms can take a straight $25 \%$ deduction for royalty payments. Usually this deduction is greater than the actual royalty, thus it becomes a special allowance. Oil companies are also responsible for road access fees, whether to the government or private landowners (IEA 1992c). 


\section{Refined Oil}

Background: Refinery capacity reached 313,000 cubic meters per day in 1990 . Imports comprised $36 \%$ of crude oil receipts at refineries (IEA 1992b).

Government Ownership of Business Entities: Refining and distribution is open to the private sector. With privatization of Petro-Canada, the major players will all be private. Petro-Canada, Esso, and Shell control $60 \%$ of the Canadian refinery market (IEA 1992c).

Investment and Production Restrictions: No lead is allowed in gasoline and sulphur contents are set at the provincial level. Only Prince Edward Island restricts the number of outlets available for consumers. There are no restrictions on foreign ownership of refineries and facilities (IEA 1992c).

Distribution Restrictions: Pipelines are regulated by provinces and by the National Energy Board when they cross provincial borders or the international border (IEA 1992c).

Trade Policies: There are no quantitative restrictions on imports. There are import tariffs of up to $20 \%$ ad valorem on certain lubricating oils (IEA 1992c). Import tariffs average about $1 \%$ ad valorem, but under NAFTA they will be eliminated on trade with the United States and Mexico within a 10-year period.

Price Controls: Prices are not controlled except on Prince Edward Island, which has regulations and controls in place for distribution and pricing margins (IEA 1992c).

Taxes: The Federal Goods and Services Tax (GST), at $7 \%$, is levied against all products and is refundable for commercial ventures. All fuels are also subject to Federal excise tax and provincial consumption taxes (IEA 1992c).

\section{Natural Gas}

Background: Gas is produced primarily in the western provinces. Alberta produces about $85 \%$ of Canada's natural gas, followed by British Columbia (10\%) and Saskatchewan (5\%) (IEA 1993a). Canada had a 10\% share in the U.S. natural gas market in 1992 (IEA 1993a).

Government Ownership of Business Entities: Private companies obtain licenses for exploration and development along the lines of that described under crude oil (IEA 1992c).

Government Ownership of Natural Resources: This is the same as for crude oil (IEA 1992c). 
Investment and Production Restrictions: The provinces can regulate the rate of production for given wells, environmental controls, and access to provincial pipelines. There are removal permits, prohibitions on direct sales to end users by producers, and core market restrictions which impede market competition (IEA 1992c).

Distribution Restrictions: The pipelines are all owned by private sector companies. The National Energy Board Act provides access to pipelines by third parties. Local distribution is carried out by regulated, but privately owned, monopolies (IEA 1992c).

Trade Policies: There are no restrictions on the import of gas. The National Energy Board regulates the Canadian section of import pipelines (IEA 1992c). The National Energy Board regulates exports of natural gas. Regulations have become less stringent since 1985 (IEA 1992c).

Price Controls: There are no price controls on natural gas. Export prices are negotiated between buyer and seller. The government monitors prices (IEA 1992c).

Taxes: Production taxes for natural gas are the same as that for crude oil. In addition, the Federal GST of $7 \%$ applies to natural gas. The Federal GST is refundable for business use (IEA 1992c).

\section{Coal}

Background: Coal production occurs mainly in the western provinces. Direct subsidies are paid to maintain coal mining in New Brunswick and Nova Scotia (IEA 1992c).

For multiple, steeply dipping seams, Canadian total mining costs are lower than those for similar U.S. mines. Total Canadian regulatory costs, including health, safety, and environmental regulatory costs, are roughly 9 to $54 \%$ of the estimated level of U.S. costs for this type of mine. The level of Canadian environmental costs alone were roughly 13 to $82 \%$ of the level of estimated U.S. costs. The United States estimated costs were based on a simulation from one U.S. mine (DOI 1993).

Canadian few-level, thick-seam mines have a higher total cost than similar U.S: coal mines. Canadian health and safety costs are lower than comparable U.S. costs for this type of mine, but environmental costs are on average higher, resulting in total regulatory costs somewhat higher than similar U.S. costs (DOI 1993).

Government Ownership of Business Entities: Provincial governments determine leases on exploration and development of coal mines. Mines in Nova Scotia and New Brunswick are federally and provincially owned, respectively. Local electric utilities have contracts with the Nova Scotia and New Brunswick mines. Not all of Nova Scotia's coal is contracted for by local utilities (IEA 1992c).

Government Ownership of Natural Resources: Provinces own almost all the coal resources (IEA 1992c). 
Investment and Production Restrictions: The Canadian Government maintains a policy of 50\% minimum ownership by Canadian interests (IEA 1992c).

Distribution Restrictions: The federal and provincial governments control or own transportation and export facilities (IEA 1992c).

Trade Policies: There are no controls on imports or exports and there are no import duties (IEA 1992c).

Price Controls: Coal is sold at market prices (IEA 1992c).

Subsidies: Nova Scotian mines are subsidized by the federal government with some operating expenses and capital expenditures (IEA 1992c).

The British Columbian Railway is provincially owned and the Canadian National Railway is federally owned. The British Columbian and Canadian Federal governments provided approximately US\$1.2 billion of the US $\$ 2.5$ billion in financing required to develop the metallurgical coal industry in the British Columbia and Alberta Provinces. They provided the funds to build new railroads and links to current railroad lines (DOC and DOI 1988).

Taxes: The provinces extract royalties from production. Consumption of coal is subject to the GST of $7 \%$, refundable if it is a business input (IEA 1992c).

\section{Nuclear}

Background: There are 19 nuclear energy plants operating in Canada. There are plans for one more nuclear power plant to come online in 1993 and three more during the next 25 years (IEA 1992b). Canada is the world leader in production and export of uranium (IEA 1993a).

Government Ownership of Business Entities: Nuclear power is a mixture of public and private companies. Atomic Energy of Canada LTD is primarily in charge of research, development, and design of reactors. Provincial utilities own and operate the nuclear power facilities (IEA 1992c).

Government Ownership of Natural Resources: Provinces own the uranium resource and there is a $51 \%$ minimum Canadian ownership requirement in the final stages of production. There is a mix of public and private companies exploring and developing uranium resources. Exports are only allowed to countries which comply with strict nonproliferation agreements. All uranium export contracts are reviewed by the Canadian government to ensure that fair returns are provided to Canadian citizens. Prices are expected to be at world market prices (IEA 1992c). 
Investment and Production Restrictions: Licensing new plants is a three-step process: site approval, construction approval, and operating license approval (IEA 1992c).

Subsidies: There may be government support in servicing CANDU reactors owned by the utilities (IEA 1992b).

\section{Electricity}

Background: In 1991, electricity was primarily generated by hydropower $(60.7 \%)$, followed by coal fired generation $(17.4 \%)$, nuclear $(16.7 \%)$, oil (2.6\%), and natural gas (2.0\%) (IEA 1993a).

Canada exported about $4.1 \%$ of its electricity generation to the United States in 1991. Hydroelectricity accounted for $72 \%$ of Canada's electricity exports in 1991. Ontario is the only province with net imports of electricity (IEA 1993a).

Government Ownership of Business Entities: Most provinces own their electric utilities, with the exception of Alberta and Prince Edward Island. These provincially owned utilities produce $85 \%$ of Canada's electricity. In Alberta and Prince Edward Island, electric utilities are privately owned and provincially regulated. Each province has its own legislation covering electric generation. Most provinces have legislation requiring public utilities to purchase privately generated electricity (IEA 1992c).

Investment and Production Restrictions: Most utilities have policies stating the rates at which they will purchase power from independent producers. But independent power generators cannot sell to third parties because utilities will not give access for transmission (IEA 1992b). Foreign investment is subject to review for U.S. nationals at C\$150 million or more. For other nationalities, the threshold is C\$5 million for direct acquisitions and C\$50 million for indirect acquisitions (IEA 1992c).

Distribution Restrictions: Distribution is regulated by the provinces. The National Energy Board regulates only interprovincial and international transmission (IEA 1992c).

Trade Policies: Canada has no restrictions on imports and no import tariffs (IEA 1992c). Canada grants two types of licenses for electricity export, one which requires Governor in Council approval and one which does not. Four items affect the designation: the effect of the export on other provinces, whether others wishing to buy the electricity have been given equal opportunity, impact on the environment, and any other matter the board wishes to include (IEA 1992c).

Price Controls: Prices are regulated by the provinces by average cost-based tariffs rather than marginal cost-based tariffs. Rates are low enough to penetrate the residential heat market (IEA 1992c). 
Subsidies: The Federal Government will either provide financing for $50 \%$ of the capital cost of interconnections, or $50 \%$ of study costs, if adequate provincial resources are unavailable, the line is economically justified, and the line results in energy conservation, increases energy security, or regional rationalization of energy costs (IEA 1992c). Most provincial utilities receive provincial bond rates, usually below the commercial rate for financing. They also receive debt guarantees from the provinces. ${ }^{(a)}$

Taxes: The GST applies at 7\%. Business may get a refund (IEA 1992c).

\section{Renewable Energy}

Background: Biomass provides about half of the energy used in the pulp and paper industry (IEA 1992b).

Government Ownership of Business Entities: In general, provincial utilities usually will buy surplus electric power (IEA 1992c).

Subsidies: The Federal government provides accelerated depreciation of alternative energy resource capital investment, especially for small hydropower, solar, and wind energies (IEA 1992c).

(a) Personal communications with Jim Campbell, Director Economic Analysis, Energy Policy Branch, Natural Resources Canada, 3/29/94. 


\section{France}

\section{All Sectors}

Background: Nuclear power accounts for $79 \%$ of domestic energy production (86.3 million metric tons oil equivalent [MTOE]) in 1991 (IEA 1993a).

Energy Supply: Energy supply in 1990 as a share of the TPES was Oil, 40.4\% (96\% imported); nuclear, $37.0 \%$; natural gas, $11.3 \%$ (90\% imported); coal, $9.1 \%$ (64\% imported); renewable energy resources, $3.9 \%$; and electricity trade, $-1.8 \%$ (IEA 1992b).

Trade: About half of French energy demand is met by imports (IEA 1992c). In 1991, oil accounted for the largest share of net energy imports, accounting for $72 \%$ or $90.3 \mathrm{MTOE}$. Imports accounted for the bulk of gas supplies (26 MTOE in 1991), with Russia being the leading supplier (34\%), followed by Algeria (31\%), Norway (20\%) and the Netherlands (15\%) (IEA 1993a).

Policies: The Ministry of Industry is in charge of most of the energy-related industries. It shares authority over the Agence de l'Environnement et de la Maitrise de l'Energie (Ademe) with the Ministry of Research and Technology and the Ministry of the Environment (IEA 1992c).

Stated French policy objectives include developing more indigenous energy sources, especially nuclear; diversifying their type and sources of energy; promoting energy efficiency and the environment; cooperating in unifying the European energy market; and stabilizing the oil market (IEA 1992c).

Government Ownership of Business Entities: France's energy sector is dominated by state-owned companies: Electricite de France (EdF), Gaz de France (GdF), Charbonages de France (CdF), and the Commissariat al l'Energie Atomique (CEA) (nuclear energy) (IEA 1992c).

Energy and the Environment: The government has set a goal of the year 2000 as the point for stabilizing $\mathrm{CO}_{2}$ emissions. Maximum levels are set for sulfur and lead contents in fuels (IEA 1993a).

In 1990, northern European industry spent about $0.9 \%$ of its GDP and US\$194 per capita on environmental equipment and protection. ${ }^{(a)}$ The French private sector expenditures as a share of the GNP were about $0.33 \%$ in 1990 , compared with $0.86 \%$ for the United States. The difference between environmental regulation enforcement in the United States and France is relatively wide (OTA 1994). The French spent about US $\$ 10$ billion in 1990 on environmental equipment and protection or about $0.84 \%$ of their GDP and US\$177 per capita. The OECD expects sales to grow at 5.5\% annually, to about US\$15 billion in the year 2000 (OECD 1992).

(a) Organization for Economic Co-operation and Development (OECD). "Environmental Cost and Industrial Competitiveness." OECD, Paris, France. Restricted document, draft, 5/20/92. 
Taxes: There is a tax on emission on $\mathrm{SO}_{2}$ (IEA 1992c). The emission tax is FF 150 per metric ton of $\mathrm{SO}_{2}$ emitted. $\mathrm{NO}_{x}$ is taxed at the same rate in $\mathrm{SO}_{2}$ equivalents (IEA 1992b).

Government-Sponsored $R \& D$ : France's energy technology priorities are focused on supply-side technology. Total R\&D spending in 1990 was about FF 3.2 billion or about $0.049 \%$ of the GDP. Estimated 1992 government R\&D funding provided nuclear power with $88 \%$ of the total; gas and oil, $6 \%$; energy conservation, 3\%; renewables, 2\%; and coal, 1\% (IEA 1993a). Between 1983 and 1986, the government provided grants equaling FF 1.3 billion to investors developing energy plants supplanting coal or providing energy conservation. These subsidies were abolished in 1986 (IEA 1992b).

\section{Crude Oil}

Background: In 1990, the Middle East provided 44\% of France's crude oil imports (Saudi Arabia [20\%], Iran [12\%], and other Middle East Countries [11\%]). Africa, (Algeria, Cameroon, Gabon, Libya, and Nigeria, primarily) (28\%), the United Kingdom, and Norway (15\%), the Former Soviet Union (7\%), and Mexico (3\%) provided most of the rest (IEA 1992b).

Government Ownership of Business Entities: The French Government is in the process of divesting itself of its two major gas and oil companies. In 1991, the French Government owned over $51 \%$ of Elf-Aquitaine (Elf) (IEA 1992c). Privatization of Elf was to begin in early 1994 with the government retaining a golden share and voting and nonvoting representatives (OGJ 1994b). Essentially Elf was sold in name only. Most of the shares were bought by French banks, which are government owned. ${ }^{(a)}$ In the summer of 1992, the Government reduced its holdings in the oil company Total to 5\% (IEA 1993a).

Government Ownership of Natural Resources: All crude oil resources belong to the government, which licenses exploration and development (IEA 1992c).

Investment and Production Restrictions: The government issues licenses for oil and gas exploration. The license duration depends on the size of the deposit. Deposits over 300,000 metric tons can be obtained for up to 50 years with possibilities for further extension. Smaller deposits are licensed for five years with the possibility of two additional five-year extensions (IEA 1992c).

There are no restrictions on foreign ownership of exploration and development companies (IEA 1992c).

Trade Policies: There are no import, export, or import duties on crude oil products (IEA 1992c).

(a) Personal communication with Clement (Clem) Malin, Manager, International Government Relations, Texaco, 4/12/94. 
Price Controls: There are no price controls (IEA 1992c).

Subsidies: There are no direct payments to the oil industry (IEA 1992c). Taxes can be deferred for five years. If exploration expenses are greater than taxes owed, the tax is forgiven. ${ }^{(a)}$

Government-Sponsored $R \& D$ : The second largest category of $R \& D$ spending is oil and gas production, refining, and end-use technology (6\%) (IEA 1993a).

Taxes: Federal government royalties reach up to $12 \%$ ad valorem, depending on the level of production. Corporate taxes are also paid; $34 \%$ for net profits after dividends and $42 \%$ on dividends. The Departments and Communes also collect production taxes (IEA 1992c). The government halved the royalty on production of oil and gas in fields developed after January 1, 1992 to promote exploration and development in France (IEA 1993a).

\section{Refined Oil}

Background: Western Europe accounted for $56 \%$ of the imports and $72 \%$ of the exports of refined products in 1990 (IEA 1992b).

Government Ownership of Business Entities: Elf holds over 25\% of France's domestic market. Total, with $5 \%$ government ownership, has just under $25 \%$ of the domestic market. The refinery industry is seen as a major energy security issue (IEA 1992c).

Investment and Production Restrictions: There are no restrictions on foreign ownership of refineries. The French government, however, sees the energy sector as a key to internal security (IEA 1992c).

Distribution Restrictions: The 1993 French oil industry law moves towards opening the refining market in France. However, French refiners must still use more costly French-flag crude carriers. The government still controls strategic decisions and investments in the refining sector (IEA 1993a).

Trade Policies: A 1992 law amends the original Oil Law of 1928 to free up the movement of oil products. The law also provides for new stockholding arrangements, maintains part of the requirement that refiners must use French-flag crude tankers, and gives the French Government the right to oppose any refinery projects involving shutdowns, plant construction, and asset disposals on grounds of supply security and market stabilization (IEA 1993a). As of 1993 there were no import or export controls on refined products (IEA 1992c). The European Community (EC) General Tariff schedule applies to refined oil imports (IEA 1992c).

(a) Personal communication with Gordon Barrows, Barrows and Company, 4/4/94. 
Price Controls: The government maintains the right to control prices during times of emergency (IEA 1992c).

Subsidies: . There are no direct payments to producers of refined oil products (IEA 1992c).

Government-Sponsored $R \& D$ : In 1992, the second largest category of R\&D spending was for oil and gas production, refining, and end-use technology (6\% of the total) (IEA 1993a).

Taxes: Heavy fuel oil with sulfur content of less than 2\% has a FF 35 advantage over other heavy fuel oils (IEA 1992b). Taxes on oil products include $18.6 \%$ value added tax (VAT) (reimbursable for commercial purposes except gasoline); excise taxes; fees contributed to the Institute Francais du Petrole and the Hydrocarbon Fund, and a tax to compensate filling station owners who leave the business (IEA 1992c).

\section{Natural Gas}

Background: The French and United Kingdom governments are discussing the possibility of a crosschannel gas pipeline, and GdF continues to monitor progress on the construction of the trans-Morocco (Mahgreb) pipeline from Algeria to Spain. France could take deliveries of piped gas (through the Mahgreb pipeline) as an alternative to existing LNG supply contracts (IEA 1993a). Current plans for the Mahgreb-Europe pipeline call for construction to begin in 1994, delivery of the first gas to Spain in 1996, then later possibly to Portugal, France, and Germany (Koen and True 1994b).

France is the second largest importer after Japan of LNG. In 1990, the Former Soviet Union (31\%) and Algeria (30\%) provided most of France's natural gas imports, followed by Norway and the Netherlands (IEA 1992b).

The GdF, the wholly state-owned gas utility, is seeking new supplies to meet forecasted increases in demand. To do this, the GdF signed a contract with Nigeria for 500 million cubic meters a year of LNG, representing about $1.5 \%$ of total French requirements (IEA 1993a).

Government Ownership of Business Entities: Elf controls about $97 \%$ of production. Lease arrangements are identical to those in crude oil (IEA 1992c).

Government Ownership of Natural Resources: Gas resources are owned by the government (IEA 1992c).

Distribution Restrictions: There are restrictions on foreign ownership in distribution because GdF has a monopoly on distribution. There are no restrictions on production (IEA 1992c).

Trade Policies: The GdF, a government-owned company, has a monopoly in the importing and exporting of natural gas. There are no import tariffs (IEA 1992c). 
Price Controls: Price changes to small consumers must be approved by the Ministry of Industry. Prices to large consumers are not controlled, but changes are reviewed by two ministries to prevent cross subsidization (IEA 1992c).

Subsidies: There are no direct payments to the gas industry (IEA 1992c). Taxes can be deferred for five years. If exploration expenses are greater than taxes owed, the tax is forgiven. ${ }^{(a)}$

Government-Sponsored $R \& D$ : The second largest category of $R \& D$ spending is oil and gas production, refining, and end-use technology (about 6\% of total R\&D spending) (IEA 1993a).

Taxes: Production over $300,000 \mathrm{~m}^{3}$ is subject to a $5 \%$ royalty. Consumers, except commercial entities, pay the $18.6 \%$ VAT ( $5.5 \%$ on fixed charges); and a special tax of 0.59 cents $/ \mathrm{kWh}$ on consumption exceeding 5 gigawatt hours (GWh)/year. Gas as an input in production is exempt from the special tax (IEA 1992c).

\section{Coal}

Government Ownership of Business Entities: The CdF, a government-owned group, owns and operates all French Coal mines. A subsidiary, Houilleres du Bassin, works the coal mines in Lorraine, the Pasde-Calais, the center, the north, and the south (IEA 1992c).

Government Ownership of Natural Resources: The French Government effectively owns the coal (IEA 1992c).

Investment and Production Restrictions: The CdF's legal position effectively excludes foreign ownership (IEA 1992c).

Trade Policies: Imports appear to be highly controlled by the government, both through a quasi-government bargaining unit and by government oversight on board purchasing decisions and licensing of imports. There are no import tariffs (IEA 1992c). There are no export restrictions (IEA 1992c).

Price Controls: Prices are based on international market prices, (IEA 1992c) even though costs are estimated to be almost twice the level of the international market price. ${ }^{(b)}$

(a) Personal communication with Gordon Barrows, Barrows and Company, 4/4/94.

(b) Personal communications with John Rassmussen, Trade Specialist, Office of Energy, International Trade Administration, U.S. Department of Commerce, 4/4/94 and Arthur Rypinski, Petroleum and Refining, Energy Information Administration, U.S. Department of Energy, 5/11/93. 
Subsidies: French coal production depends heavily on government subsidies. These totalled about FF 7 billion between 1988 and 1990. About FF 3.2 billion went towards current expenses and FF 3.8 went towards past production (IEA 1992c). In 1990, production costs were estimated at $\$ 70$ per metric ton while CIF prices were $\$ 40$ per metric ton. France is progressively closing uneconomic mines to reduce state subsidies (IEA 1993a).

Government-Sponsored $R \& D$ : Some funds are allocated to develop clean and efficient coal use, renewable energy sources, co-generation, energy efficiency and conservation, and transport sector technology (IEA 1993a).

Taxes: Households are charged the current VAT of $18.6 \%$ on coal consumption (IEA 1992c).

\section{Nuclear}

Government Ownership of Business Entities: All sectors of the nuclear energy sector are dominated by government or quasi-government companies from technology development (the CEA), to enrichment and processing (Compagnie Generale des Matieres Nucleaires [COGEMA]), to EdF owning and operating the nuclear power stations (IEA 1992c).

Government Ownership of Natural Resources: France has about $3 \%$ of the world's known uranium resources (IEA 1992b).

Government-Sponsored $R \& D$ : Nuclear power accounts for the overwhelming majority of state energy R\&D spending ( $88 \%$ of a total FF 3.15 billion spent in 1992) spanning light-water design, reactor safety, the fuel cycle, breeder development, and nuclear fusion (IEA 1993a).

The EdF is part of a European consortium with four German utilities, Framatome, and Siemens, to pool financial and technical resources with the aim of building a new prototype reactor (IEA 1993a).

\section{Electricity}

Background: Nuclear power accounted for $73.6 \%$ of electricity generation in 1991, and coal, about $9.6 \%$ (IEA 1993a). In 1990, oil accounted for about $2 \%$ and hydropower about $13 \%$ of electricity generation (IEA 1992b). New nuclear capacity is coming on line at the rate of about three reactors every four years (IEA 1993a).

In 1990, exports accounted for $13 \%$ of production. The main recipient countries were Switzerland, 26.9\%; Italy, 25.0\%; United Kingdom, 23.0\%; Germany, 8.7\%; the Netherlands, $8.7 \%$; and Belgium, 7.4\% (IEA 1992b). 
Government Ownership of Business Entities: The EdF is a $100 \%$ government-owned business that generates and distributes electricity in France (IEA 1992c).

Investment and Production Restrictions: Foreign ownership of production and distribution facilities is effectively eliminated by the EdF's monopoly position. The EdF does have some joint facilities with foreign companies (IEA 1992c).

Distribution Restrictions: There are restrictions on foreign ownership in distribution because the EdF has a monopoly and French law does not provide for third party access. About 200 small companies, mainly local or public entities, distribute about $5 \%$ of the electricity. Written approval with public comment is necessary before construction of high voltage electricity lines (IEA 1992c).

Trade Policies: The EdF monopolizes trade. There are no import tariffs (IEA 1992c).

Price Controls: The EdF is drawing up a new electricity tariff structure for the residential sector with tariffs better reflecting supply costs. Industrial and commercial customers have a choice of eight variable tariffs (IEA 1993a). Price changes are supervised by the Ministry of Industry and approved by the Ministry of Finance (IEA 1992c).

Subsidies: The government is providing an exemption from natural gas excise taxes for gas consumed in electric cogeneration plants installed during 1993 and 1994.

Government-Sponsored $R \& D$ : The government has approved projects to promote cogeneration and electric energy conservation worth about FF 100 million during 1993-1995 (IEA 1993a). The EdF is also providing FF 150 million to develop battery charging facilities to charge electric motor vehicles. The EdF has also undertaken a FF 10 billion project to modernize thermal generating plants to meet emissions requirements.

Taxes: The VAT of $18.6 \%$ is collected on electricity purchases. Commercial entities can get the VAT refunded. Municipal and department taxes have a ceiling of $8 \%$ and $4 \%$, respectively.

\section{Renewable Energy}

Government Ownership of Business Entities: The Compagnie Nationale du Rhone, a state-owned company, is responsible for all hydroelectric power on the Rhone river. The EdF controls most of the remaining hydroelectric power (IEA 1992c).

Investment and Production Restrictions: Independent generation can be developed by private entities and electricity must be purchased by EdF (IEA 1992c). 
Government-Sponsored $R \& D$ : In 1990, the government spent about $2.4 \%$ (FF 77 million) of the total R\&D expenditures on renewable energies (IEA 1992c). The photovoltaic industry is a primary investment area for the French Government (IEA 1992b).

The French Assembly (Assemblee Nationale) is encouraging the production and use of biofuels in the transport sector, primarily in blends with gasoline or diesel. The government approved a FF 25 million experimental program to produce methyl-ester from rapeseed grown on land that would otherwise be fallow under EC farm rules. An accord between the Government, two industrial ester producers and the two French oil companies, Total and Elf, was signed in February 1993 to set production targets for rapeseed methyl-ester. Methyl-ester is produced from rapeseed to be used as a diesel fuel (IEA 1993a). 


\section{Mexico}

\section{All Sectors}

Background: The energy sector is important to the Mexican economy. In 1991, Petroleos Mexicanos (PEMEX), the major state-owned petroleum company, accounted for $8 \%$ of Mexico's GDP, and onethird each of its foreign exchange and tax revenue (EAI 1992a).

Energy Supply: In 1991, Mexico's primary energy supply came mainly from oil, (70\%); followed by gas, (21\%); hydro, (5\%); coal, (3\%); and nuclear, (1\%) (IEA 1993b).

Trade: In 1991, imports supplied about 7\% of Mexico's TPES. Refined oil and natural gas accounted for almost all of the imports.

Policies: Almost all activities related to the ownership and development of energy resources and the operation of entities in the energy area are reserved by the state under the Mexican Constitution (Constitution of the United Mexican States, articles 25, 27, and 28). The NAFTA contains reservations by Mexico on virtually all energy-related activities in that country, including ownership and development of resources and investment and provision of services regarding crude oil, natural gas, artificial gas, basic petrochemicals, pipelines, supply of electricity as a public service, and radioactive materials. The NAFTA also permits Mexico to restrict trade through the granting of import and export licenses in many of the energy sectors, including petroleum oils and gases (USITC 1993).

Government Ownership of Business Entities: Mexico's energy sector is characterized by state ownership: the PEMEX, the oil company; and Comision Federal de Electricidad (CFE), the electric company. The PEMEX has recently been restructured into a holding company with four subsidiaries (exploration and production, refining, natural gas and basic petrochemicals, and secondary petrochemicals.) Almost all of Mexico's energy sectors are controlled by these two parastatal entities. Mexico's constitution requires state ownership of hydrocarbon resources, the exploration for and the development of them, as well as the operation of any entities in the energy area. The NAFTA does not change any constitutional provisions. Under the NAFTA, some amendments will be made to allow foreign investment in electricity generation and nonbasic petrochemical production. Also, some regulatory reform on the monopoly powers of the PEMEX and the CFE will allow companies investing money in the Mexican energy sectors to get the oil and electricity inputs necessary to operate (USITC 1993).

Under NAFTA, U.S. companies can invest in electricity generation and nonbasic petrochemical manufacture. Starting in 1994, U.S. companies can only invest in or take possession of companies with values of less than $\$ 25$ million without having government approval. This will increase over the next decade to $\$ 150$ million (USITC 1993). 
Energy and the Environment: Latin American environmental, health, and safety regulations lag considerably behind the United States at present. Best case scenarios show that in 1990 the best Latin American countries implemented environmental regulations at $30 \%$ of those in the United States. The study indicated Latin American regulatory implementation would improve to 40, 50 and $70 \%$ by 1995 , 2000 , and 2010 , respectively. Worst case scenarios were 10 percentage points less in each case addressed. ${ }^{(a)}$

Subsidies: Electricity is the only energy sector with substantial direct subsidies (GATT 1993b).

Government-Sponsored $R \& D$ : There is no direct government assistance for research and development. And there are certain regulations which are meant to foster R\&D (GATT 1993b). As governmentowned companies, the government is still indirectly responsible for R\&D.

\section{Crude Oil}

Background: Mexico is the world's sixth largest oil producer, with the eighth largest proven reserve base (GATT 1993b). Mexico is also a large producer of high sulfur crude oil (Baker 1994). As of January 1, 1993, Mexico has proven oil reserves of 51 billion barrels (bb), oil production capacity of $3.2 \mathrm{mbd}$, oil production of $3.1 \mathrm{mbd}$ ( $2.6 \mathrm{mbd}$ is crude oil), natural gas reserves of 71 trillion cubic feet, and natural gas production of $1.3 \mathrm{tcf}$ (EAI 1993).

Mexico produces only one-fourth as much oil as the United States, but exports about half of its crude oil. In oil, Mexico is a net exporter to the United States, Japan, Spain, and France. In 1990, the United States bought $56 \%$ of Mexican exports, followed by Spain (17\%), Japan (11\%) and France (4\%). In 1990, the United States imported 689,000 bd from Mexico (EAI 1992a).

Government Ownership of Business Entities: Under Mexican law, only the PEMEX can produce crude oil (USITC 1993). Under new management, the PEMEX has developed innovative financing methods by foreign firms. This allows foreign firms to participate in oil exploration without outright ownership of hydrocarbon resources (EAI 1992a).

Government Ownership of Natural Resources: The Mexican Government owns crude oil deposits through the PEMEX (EAI 1993).

Investment and Production Restrictions: The PEMEX often contracts out drilling services to foreign firms without providing for "risk sharing" or foreign equity in the subsoil of hydrocarbons. The NAFTA provision for performance clauses should reportedly make drilling contracting more favorable.

(a) Bracewell and Patterson, L.L.P. Submission to the U.S. Department of Commerce concerning "Comments on the Initiation of National Security Investigation of Imports of Crude Oil and Petroleum Products." Washington, D.C., 5/12/94. 
This provision brings Mexican drilling contracts more in line with world standards (USITC 1993). The performance clauses also make it easier for small independent contractors to obtain financing (CBO 1993).

Under the government procurement provisions of the NAFTA, foreign firms can bid on a maximum of $50 \%$ of the PEMEX contracts on a nondiscriminatory basis under a transparent bid and evaluation process, but the NAFTA does not guarantee any percentage of the contracts go to foreign firms. This maximum is effective immediately and becomes $100 \%$ over 10 years. The PEMEX and the CFE, together, may set aside $\$ 300$ million for domestic contractors. Formal public invitations are not generally used, rather the PEMEX obtains quotations informally from the foreign suppliers. However, under the NAFTA, the PEMEX must establish procurement procedures that notifies potential the NAFTA suppliers of procurement opportunities and evaluates their bids on an equal basis to domestic contracts. It also must provide a forum for losing bidders to challenge tenders and awards (CBO 1993; USITC 1993).

In 1991, the U.S. EXIM Bank and Mexico agreed to a $\$ 5.6$ billion, five-year loan package for exploration and production projects with U.S. companies. In late 1991, opposition to the use of foreign contractors delayed the issue of more tenders and could undermine U.S. involvement (EAI 1992a).

Distribution Restrictions: The PEMEX is the monopoly owner of oil in Mexico. (EAI 1992a; USITC 1993).

Trade Policies: Mexico uses tariffs and import and export licenses to regulate trade. In addition, Mexico places quantitative quotas on certain goods, prices domestic and imported goods differently, and restricts foreign access to government procurement and investment. Under the NAFTA, only a portion of these restrictions were addressed. The NAFTA provides for the elimination of the $5 \%$ ad valorem for U.S. and Canadian imports over a 10-year period, but Mexico will retain the right to price domestic and imported energy products differentially (CBO 1993). The PEMEX controls exports of all petroleum products (GATT 1993b).

Price Controls: The PEMEX is the monopoly buyer of oil and oil products and prices domestic and imported products differentially (CBO 1993). According to the GATT, in 1991, the Mexican oil and gas industry prices were lower than international market prices (GATT 1993b).

Taxes: Effective January 1, 1994, the government imposed a new tax on all four PEMEX subsidiaries. Prior to this, $60 \%$ of the PEMEX's gross revenues was paid to the federal treasury. The new tax on. PEMEX Exploration and Production (E\&P) is similar to taxes levied in the United Kingdom and Norway. The tax rate is dependent on productivity and depreciation. Highly profitable extraction areas could be taxed as high as $90 \%$ while less profitable ones would be taxed as low as $30-40 \%$. Under the new tax structure, E\&P is taxed for flared gas as well as oil extraction in an attempt to make 
the PEMEX build infrastructure to capture and exploit more of its natural gas potential. The second tax on refined oil products is explained under refined oil taxes. The third tax is a straight $34 \%$ income tax on net profits (Baker 1994).

\section{Refined Oil}

Background: As of 1992, Mexico had refining capacity of $1.5 \mathrm{mbd}$. United States firms, such as Texaco and HRI have contracts to provide technical assistance on Mexico's environmental problems associated with refining oil (EAI 1992a).

Roughly one-third of the PEMEX's five-year \$20 billion capital spending plan is targeted to increase oil refinery capacity. Plans are being made for 12 petrochemical projects. During 1991, three refineries were closed due to acute pollution problems. To ease further pollution problems and to help offset these closures, a $\$ 750$ million project is underway to expand and upgrade two other refineries, adding acatalytic crackers, desulfurization, and reformer units. Three U.S. firms were contracted to help with these projects (EAI 1992a).

In 1990 , the U.S. exported 89,000 bd of refined product while importing 66,000 bd (EAI 1992a).

Government Ownership of Business Entities: Mexico's constitution explicitly states that the PEMEX is the sole owner and producer of crude oil, refined oil products, natural gases, and primary petrochemicals (USITC 1993).

Investment and Production Restrictions: Foreign ownership of crude oil refining capacity is prohibited (USITC 1993). Even though the investment market for production of secondary petrochemicals is formally open for foreign investment, PEMEX, the monopoly supplier of raw products, has been unable to keep up with demand (GATT 1993b).

Distribution Restrictions: The PEMEX is monopoly exporter and importer of refined products (USITC 1993).

Trade Policies: Mexican import duties on refined petroleum average about $8.6 \%$ ad valorem. Under the NAFTA these duties will be reduced to zero over a 10-year period (USITC 1993).

Price Controls: Mexico retains the right under the NAFTA to price domestic and imported refined products differentially (CBO 1993).

Taxes: A tax is placed on retail sales of fuels and fuel oils. The tax is variable and depends on the difference between the government-controlled retail price and the Houston Producer Price. The intent is for Mexican consumers to pay a higher portion of oil taxes when international prices fall. A drop in crude oil prices will also lower the extraction fee placed on E\&P production. A straight $34 \%$ income tax is also levied on net profits (Baker 1994). 


\section{Natural Gas}

Background: In 1992, the PEMEX produced almost 3.6 billion cubic feet per day (bcfd) of natural gas (Baker 1994). Mexico's natural gas production is equal to about 5\% of the level of U.S. production (CBO 1993). Mexico has been a net importer of natural gas, importing around 250 million cubic feet per day (mcfd) (Baker 1994). The U.S. exported nearly 50 billion cubic feet (bcf) of natural gas to Mexico in 1992, about $0.5 \%$ of U.S. production (Farmer 1993b).

Five percent of the PEMEX's five-year, $\$ 20$ billion capital spending budget is targeted to increasing petrochemical production capacity (EAI 1992a). Much of what Mexico calls petrochemicals is considered natural gas by the rest of the petroleum world. Mexico's primary petrochemicals include ethane, propane, butane, pentane, hexane, heptane, carbon black feedstock, and naphthas (USITC 1993).

Government Ownership of Business Entities: Mexico's constitution explicitly states that the PEMEX is the sole owner and producer of crude oil, natural gases, and primary petrochemicals (USITC 1993).

Government Ownership of Natural Resources: Natural gas resources are constitutionally owned by the PEMEX (USITC 1993).

Investment and Production Restrictions: For secondary and tertiary petrochemicals, the NAFTA eliminated the $40 \%$ investment ceiling on foreign firms in the case of the United States and Canada (USTIC 1993). As the PEMEX controls the raw product, investment in secondary and tertiary refinement can be risky because there is a lack of guaranteed raw product supply. Secondary petrochemicals include acetylene, ammonia, benzene, butadiene, butylene, ethylene, methanol, n-paraffins, orthoxylene, para-xylene, propylene, toluene, and mixed xylenes (USITC 1993). The NAFTA, however, moved more than half of the items listed as primary petrochemicals to secondary petrochemicals (CBO 1993).

Distribution Restrictions: The PEMEX continues to own and operate the pipeline system for delivery of gas to Mexican purchasers (CBO 1993; ITC 1993). The NAFTA allows U.S. and Canadian gas exporters to negotiate directly with potential end users for gas purchases. The PEMEX would be engaged as an interested third party (transmission is owned by the PEMEX). In reality the PEMEX would probably buy and resell the gas to the end user (CBO 1993).

Trade Policies: Import duties on natural gas and butane are $10 \%$ ad valorem and will be phased out over 10 years for U.S. and Canadian exporters (Farmer 1993b).

Price Controls: Under the NAFTA, Mexico retained the right to price domestic and imported oil and gas products differentially (CBO 1993). Basic petrochemicals are subject to price controls (GATT 1993b). According to the GATT, the Mexican oil and gas prices were lower than international market prices in 1991. 
Taxes: See the section on crude oil for a description of taxes.

\section{Coal}

Background: Mexico produces very small quantities of coal (CBO 1993).

Government Ownership of Business Entities: Private firms can explore for coal (CBO 1993).

Investment and Production Restrictions: The NAFTA allows for unrestricted participation in foreign trade, production and distribution, and marketing of coal (CBO 1993). In 1992, Mexico allowed for $100 \%$ investment in exploration, a 30-year renewable trust, and up to $100 \%$ investment in exploitation (GATT 1993b). Purchases of existing mines are limited to $49 \%$ for the first three years from the point of the initial sale. Investment can increase to $100 \%$ after that (USITC 1993).

Distribution Restrictions: There are no distribution restrictions to the United States and Canada (CBO 1993).

Trade Policies: The NAFTA eliminates Mexico's 10\% tariff on coal imports from Canada and the United States immediately (CBO 1993). According to the GATT, coal mining has a $12 \%$ level of protection (GATT 1993b). Protection is afforded primarily through the $10 \%$ tariff on imported coal (CBO 1993).

Price Controls: There are no price controls on coal.

Subsidies: The Mexican Government provides risk-shared capital financing to encourage small and medium-sized firms to explore for coal (GATT 1993b).

Taxes: The tax on extraction of minerals was abolished in 1992 (GATT 1993b).

\section{Nuclear}

Background: Mexico took an exception with regards to its nuclear energy sector under the NAFTA (USITC 1993).

\section{Electricity}

Background: Insufficient capacity, inadequate distribution channels, and aging power plants characterizes the electricity sector. Blackouts are common. The CFE plans on spending $\$ 34$ billion building an additional 19,513 MW of capacity between 1989 and 1999. Three major hydropower 
plants are under construction and eight thermal plants have been built. Electrical generation increased $2.6 \%$ in 1992 (USITC 1993). Almost 50\% of the generation comes from fuel oil generation (Baker 1994).

Mexico is a net exporter of electricity to the United States (USITC 1993). Cross-border transmission capacity between the U.S. and Mexico almost doubled in 1992, going from 559 mcfd to 959 mcfd (Baker 1994). Mexican-electricity exports to the United States account for less than $10 \%$ of U.S. imports and less than 1\% of U.S. production (USITC 1993).

Government Ownership of Business Entities: The CFE, Mexico's state-owned utility, generates, distributes, and prices electricity. Under the NAFTA, private foreign investment will be permitted for selfgeneration of electricity, cogeneration, and independent power plants (IPPs) for industrial users only. No open market sales will be permitted in Mexico (USITC 1993). The NAFTA does not affect state and provincial regulations concerning the generation and transmission of electricity.

Investment and Production Restrictions: Under the NAFTA, companies are allowed to generate and sell excess supplies of electricity to the CFE (CBO 1993).

Distribution Restrictions: The CFE owns all transmission lines.

Trade Policies: Under the NAFTA, Mexico will eliminate a $10 \%$ ad valorem import duty on electricity over a five-year period (USITC 1993).

Price Controls: The CFE is the monopoly buyer and seller of electricity in Mexico and, as such, determines prices in accordance with the policies of the Mexican Government (USITC 1993). 



\section{The Netherlands}

\section{All Sectors}

Background: The Netherlands primarily produces natural gas, small quantities of crude oil, and nuclear energy. It does not produce no coal (IEA 1993a).

Energy Supply: The TPES increased by 5.3\% from 1990 to 1991 . The share of the TPES for natural gas, in 1991, was almost 50\% higher than for any other International Energy Agency (IEA) country (49.2\% of the total in 1991). Oil accounted for $36.5 \%$ of the TPES; coal, $11.5 \%$; nuclear, $1.2 \%$; and electricity trade, $1.1 \%$ of the total. Domestic production was overwhelmingly from natural gas at $92.6 \%$, while the remainder was from oil at $5.6 \%$, nuclear at $1.3 \%$, and coal $0.3 \%$ (IEA 1993a). The Netherlands produces no coal (IEA 1992c).

Trade: The Netherlands is one of three major exporters of gas to the OECD countries in Europe. They have a large export capacity in natural gas and refined oil products. The Netherlands has a large refining sector and is a net exporter of oil products (IEA 1992c).

Electricity generation accounts for $65 \%$ of coal consumption. Coal is imported mainly from the United States, Australia, and Colombia. The Netherlands is a net electricity importer (IEA 1993a).

Policies: The Ministry of Economic Affairs is primarily responsible for energy policy on the national level. The Netherlands Agency for Energy and the Environment (NOVEM) (IEA 1993a), a government body, under the supervision of the Ministry of Economic Affairs, is responsible for managing government policy. Municipal and provincial governments have considerable influence in siting of facilities and transmission (IEA 1992c). The government is currently considering new environmental policies concerning both on- and off-shore oil and gas exploration (IEA 1993a). The National Environment Policy Plan (NEPP) is expected to reduce coal consumption in industry (IEA 1992b).

Government Ownership of Business Entities: Business ownership is mixed in most energy sectors. Exploration for gas and oil is in the private sector, but all gas transport and marketing is by Gasunie, jointly owned by the Dutch government (50\% ownership), Shell, and Exxon. ${ }^{(a)}$

Energy and the Environment: The Government has set a goal of a 3 to $5 \%$ reduction in $\mathrm{CO}_{2}$ emissions by 2000 (IEA 1992c).

(a) Personal communications with Kornelis Blok, Professor, Department of Science, Technology, and Society, Utrecht University, The Netherlands, 3/24/94. 
In 1990, public and private industry in the Netherlands spent about $0.96 \%$ of the GDP and US\$188 per capita on environmental equipment and protection (OECD 1992). Dutch private industry expenditures as a share of the GNP were about $0.46 \%$ in 1989 as compared with $0.8 \%$ for the United States. The difference in environmental regulation enforcement between the United States and the Netherlands is relatively wide (OTA 1994). Dutch industry spent about US $\$ 2.7$ billion in 1990 on environmental equipment and protection. The OECD expects that expenditures will grow $4.1 \%$ annually to about US $\$ 3.7$ by the year 2000 (OECD 1992).

Government-Sponsored $R \& D$ : The Dutch Government spends approximately $0.057 \%$. of the GDP on $R \& D$ for energy conservation, energy diversification, and environmental protection. In 1990, the government announced a Gld 524 million program for 1992 focused on energy conservation and development. In the 1990s, this.program is expected to cost Gld 35 billion (IEA 1992b).

Taxes: The Government exacts an environmental tax of Gld 4.7 per metric ton of $\mathrm{CO}_{2}$ emission and Gld 0.39 per gigajoule (GJ). The VAT on energy products dropped to $17.5 \%$ in 1992 , but excise taxes on automotive fuels was increased by $20-25 \%$, leaving gasoline prices 1.8 and $3.6 \%$ higher for regular and premium gasolines, respectively. The environmental levies (Glds) in 1993 on fossil fuels were leaded gasoline and unleaded gasoline, 2.41 per hectolitre; diesel fuel and heating oil, 2.66 per hectolitre; coal, 22.64 metric ton; LPG, 31.83 per metric ton; and natural gas, 20.79 thousand cubic meters. (On average $1 \mathrm{Gld}=\mathrm{US} \$ 0.569$ ) (IEA 1993a).

\section{Crude Oil}

Government Ownership of Business Entities: The government is the sole shareholder of Energie Beheer Nederland (EBN) through which all licenses are granted for exploration of oil and natural gas on the Dutch continental shelf. Private companies and the Dutch Government explore for oil and gas through a joint operation called a "Cost Company." The Cost Company explores and develops, and the government gets $50 \%$ of each new concession six months after discovery (IEA 1992c).

Government Ownership of Natural Resources: The Dutch Government owns the oil resources (IEA 1992c).

Investment and Production Restrictions: There are no foreign ownership restrictions (IEA 1992c).

Trade Policies: There are no import or export controls and no tariffs (IEA 1992c).

Price Controls: There are no price controls (IEA 1992c).

Subsidies: There are no direct subsides (IEA 1992c).

Taxes: The government takes $50 \%$ of each concession after commercial discovery is made. This is called the State Profit Share. In addition, there is a royalty of up to $16 \%$ of the wellhead value, 
depending on the date of discovery. Corporate taxes are applied as well. The "Cost Companies" are exempt from the concession charges and the corporate income tax (IEA 1992c).

\section{Refined Oil}

Background: Oil accounts for about 37\% of the TPES for the Netherlands. The Netherlands produces very little of its own oil, but it is a major refiner and exporter of refined oil products (IEA 1992c).

Government Ownership of Business Entities: There is no government ownership (IEA 1992c).

Investment and Production Restrictions: There are no foreign ownership restrictions. There are limits on sulphur and lead contents for gasoline (IEA 1992c).

Distribution Restrictions: There are no distribution restrictions (IEA 1992c).

Trade Policies: There are no export or import controls. The General EC Tariff applies (IEA 1992c),

Price Controls: There are no price controls (IEA 1992c).

Subsidies: There are no direct subsidies (IEA 1992c).

Government-Sponsored R\&D: NOVEM provides little or no R\&D for crude oil, oil refining, or natural gas development. ${ }^{\text {(a) }}$

Taxes: There is an $17.5 \%$ VAT on oil products, which is refundable if the oil is used in a commercial process (IEA 1992c).

\section{Natural Gas}

In 1991, natural gas supplied about half of the Netherlands' primary energy requirements (IEA 1992c). NAM, a company owned jointly by Shell and Esso-Holland (Exxon), account for about $47 \%$ of offshore production (IEA 1992b). About 47\% of gas production was exported in 1991 (IEA 1993a).

In 1991, there were 16 operators both on and offshore, including NAM (IEA 1992b).

Government Ownership of Business Entities: The natural gas industry has a mix of private and publicly owned companies. Primary extraction tends to be in the private sector, while distribution tends to be in

(a) Personal communications with Kornelis Blok, Professor, Department of Science, Technology, and Society, Utrecht University, The Netherlands, 3/24/94. 
the public/private sector. Gasunie is owned $50 \%$ by the state and $25 \%$ each by Shell and Esso. Gasunie markets almost all the gas within the Netherlands.

Government Ownership of Natural Resources: Natural resources are owned by the government and leased to private companies through a government-owned exploration company (IEA 1992c).

Investment and Production Restrictions: Government limits production from the very large Goningen field, which is used as a swing field. Under a government "small-fields policy," priority is placed on producing from the small fields (less than $10 \mathrm{bcf}$ ). Offshore licensing bidding was last held at the beginning of 1992 and new licensing will not take place again until March 1995 (IEA 1993a).

Distribution Restrictions: Gasunie has a de facto monopoly on gas transmission because it owns the pipelines. Offshore pipelines are owned by the EBN and other private companies. Most local distribution is controlled by local authorities (IEA 1992c).

Trade Policies: There are no legal restrictions on imports, but the government has made it clear that it expects Gasunie to be involved in any gas imports. There are no import tariffs. The government must grant permission for exports (IEA 1992c).

Price Controls: Gas is monopoly priced at cost, plus transport costs and a profit margin. The Ministry of Economic Affairs oversees the tariff rate schedule (IEA 1992c).

Government-Sponsored $R \& D$ : NOVEM provides very little R\&D for the crude oil, oil refining, and natural gas sectors. ${ }^{(a)}$

Taxes: The government takes $50 \%$ of each concession after commercial discovery is made. This is called the State Profit Share. In addition, there is a royalty of up to $16 \%$ of the wellhead value. On top of that, corporate taxes are applied. "Cost Companies" are exempt from the concession charges and the corporate income tax. There is a special tax on NAM's net profits. Consumers pay the general VAT of $17.5 \%$ on gas consumption. The VAT is refundable to commercial users (IEA 1992c).

\section{Coal}

Background: Coal imports originate mainly in the United States, Australia, and Columbia (IEA 1993a).

Government Ownership of Business Entities: There is no coal mined in the Netherlands (IEA 1992c).

(a) Personal communications with Kornelis Blok, Professor, Department of Science, Technology, and Society, Utrecht University, The Netherlands, 3/24/94. 
Trade Policies: There are no import controls or tariffs (IEA 1992c).

Government-Sponsored R\&D: The Netherlands Energy Research Foundation (ECN) spent about Gld 24 million in 1991 studying coal emission and combustion technology (IEA 1992b).

Taxes: Coal is subject to a $17.5 \%$ VAT except for commercial ventures. There is an environmental tax on coal (IEA 1992c). In 1993, the environmental tax was 22.64 Gld per metric ton (IEA 1993a).

\section{Nuclear}

Government Ownership of Business Entities: Nuclear power plants are municipally and provincially owned and operated by four regionally based generating companies. The Federal government decides whether a new power plant is built or the life on a current one is extended (IEA 1992c).

Government-Sponsored $R \& D$ : The Dutch government funds nuclear fission and fusion research through specific institutes such as ECN. ${ }^{(a)}$

\section{Electricity}

Background: The Netherlands is a net importer of electricity. In 1991, imports from Germany and France covered $12.3 \%$ of Dutch electricity consumption (IEA 1993a).

Government Ownership of Business Entities: The Dutch Cooperative Public Electricity Production Companies (SEP), a group of four producing companies, owns all the main generating capacity and transmission network. All electricity production and distribution companies are owned by the provinces and municipalities. The distribution companies can buy from any indigenous producer. Independent generation is allowed by the distribution companies (IEA 1992c).

Investment and Production Restrictions: There are voluntary limits on $\mathrm{SO}_{2}$ and $\mathrm{NO}_{\mathrm{x}}$ emissions from thermal generating plants. The limits are 18,000 metric tons of $\mathrm{SO}_{2}$ and 30,000 metric tons for $\mathrm{NO}_{\mathrm{x}}$ by 2000 , approximately $28 \%$ and $38 \%$ of 1985 levels, respectively (IEA 1992c). There are no legal restrictions on foreign ownership of facilities, but in general there is no foreign ownership (IEA 1992c).

Distribution Restrictions: The electricity has to be transported over the SEP network (IEA 1992c, 1993a). Electricity is supplied by horizontally linked distribution companies that also often distribute water and gas. Distribution companies are owned by local authorities (IEA 1993a).

(a) Personal communications with Kornelis Blok, Professor, Department of Science, Technology, and Society, Utrecht University, The Netherlands, 3/24/94. 
Trade Policies: Only electricity consumers and SEP may import electricity (IEA 1993a). Distribution companies are barred from importing electricity. There are no import duties (IEA 1992c).

Price Controls: The SEP sets the tariff schedule, distribution companies add their margin, and the rate schedules must be approved by the Ministry of Economic Affairs. Electric companies are raising their tariff rates to pay for subsidies on insulation and high efficiency central heat (IEA 1992c).

Subsidies: Private investors can obtain a $25 \%$ grant for investment in cogeneration equipment (IEA 1992c).

Government-Sponsored $R \& D$ : Government $R \& D$ in this sector is focused on energy efficiency and renewable energy programs. See the section on renewable energy below.

Taxes: Electricity is taxed at the VAT rate of $17.5 \%$. This is refundable to commercial enterprises (IEA 1992c).

\section{Renewable Energy}

Background: Renewable energy is of increasing importance in Dutch energy policy, particularly as a result of the encouragement given to decentralized electricity generation by small units. As of 1992 , plans called for $28 \%$ of this capacity to be based on renewables: wind, $18 \%$; waste incineration, $9 \%$; and hydropower, $1 \%$. Photovoltaics and thermal solar energy constitute a major part of Dutch research programs, but do not yet contribute significantly to energy production. An R\&D project in biomass is also being considered (IEA 1993a).

Government Ownership of Business Entities: Private ownership is allowed and encouraged especially in areas of electricity generation, photovoltaics, and solar heat (IEA 1992c).

Subsidies: The Government provides subsidies of Gld 30 million annually for wind generation of electricity by distribution companies in the windiest of the provinces. In addition, there is Gld 30 million available for private industry investment in wind generation. Also, there is Gld 10 million in subsidies available for solar energy and solar heat (IEA 1992c).

Government-Sponsored R\&D: NOVEM receives approximately $50 \%$ of its funding from the government and the rest from the private sector. NOVEM is responsible for research, development, market penetration, and information dissemination. In 1991, NOVEM spent Gld 54 million on wind energy, 46.3 million of which was for market penetration. Other renewable energy programs receiving funding in 1991 were biomass/waste reduction, Gld 24.9 million; and renewables, Gld 37.9 million (IEA 1992b).

The ECN receives about Gld 60 million from the government for research in wind power, photovoltaics, renewables and some areas of nuclear research (IEA 1992b). 


\section{Norwáy}

\section{All Sectors}

Background: Norway produces about six times the amount of energy it consumes. In 1991, oil and gas activities represented about $14 \%$ of Norway's GNP and $32 \%$ of its export earnings. Electricity production is based almost exclusively on hydropower. Norway produces a small amount of coal (IEA 1993a).

Energy Supply: Norway's energy demand is supplied primarily by hydropower, other renewable energy, and oil. In 1991, the TPES was made up of electricity, $(43.8 \%$, almost all of which was hydropower); oil, (41.0\%); natural gas, (8.3\%); solid fuels, (4.1\%); and coal (3.7\%) (IEA 1993a).

Total energy production was 130.5 MTOE in 1991 . Oil accounted for $73.6 \%$ of this; gas, $18.2 \%$; hydropower, $7.3 \%$, solid fuels $0.8 \%$; and coal less than $0.2 \%$ (IEA 1993a).

Trade: Since 1990, Norway has become the leading IEA exporter of oil and natural gas, and is second only to Russia as non-OPEC exporters. Norway is a net exporter of electricity (IEA 1993a).

Policies: Norway's policies are intended to promote exploration and development of the continental shelf (IEA 1992c).

In awarding licenses for production, the licensing authority seeks assurance that 1) the applicant has sufficient experience to develop cost-effective concepts for exploration, development, and operation; 2) the applicant has adequate financial strength; 3 ) the applicant has an acceptable plan for exploration and exploitation of the license area; and 4) the same exploration rights are given to foreign companies as that given to Norwegian companies in a foreign company's registered country (IEA 1993a).

Norway's policies, regulations, and licensing practices are aimed at developing a national industry with advanced technology and skills. In the past, these policies gave preferential treatment to Norwegian companies, including the state oil company, Statoil. As Norway moved to join the European Economic Area, it reexamined these policies to eliminate the contentious parts of the petroleum law that allowed applications for licenses to be judged according to proposals to buy Norwegian goods and services, support Norwegian businesses, and contribute to R\&D efforts. These policies allowed Norway to acquire and develop advanced offshore technology (IEA 1993a). According to Odd Anker. Hassel and Gordon Barrows, these requirements have been abolished. ${ }^{\text {(a) }}$

(a) Personal communications with Odd Anker Hassel, Cambridge Energy Associates, 4/21/94 and Gordon Barrows, Barrows and Company, 4/4/94. 
Government Ownership of Business Entities: The government is heavily involved in the gas, oil, and electricity sectors (IEA 1992c).

Energy and the Environment: Norway has environmental goals, particularly in regard to $\mathrm{CO}_{2}$ emissions. Their $\mathrm{CO}_{2}$ taxes are among the highest in IEA countries (IEA 1993a).

In 1990 , Norway's public and private industry spent about $0.66 \%$ of its GDP and US $\$ 167$ per capita on environmental equipment and protection (OECD 1992). Norwegian industry expenditures as a percent of GNP were about 0.27 in 1985 as compared with 0.89 for the United States. The difference in environmental regulation enforcement between the United States and Norway is relatively wide (OTA 1994). Norwegian industry spent about US\$0.7 billion in 1990 on environmental equipment and protection. The OECD expects sales to grow $4.4 \%$ annually to about US\$1.0 billion in the year 2000 (OECD 1992).

Subsidies: Research and Development expenditures are treated as operational costs and are immediately deductible from income for tax purposes (IEA 1993a).

Government-Sponsored R\&D: In 1992, government R\&D spending reached about NKr 393.5 million (US\$63 million), $0.056 \%$ of the GDP. In 1991, over $30 \%$ of the expenditure was in the gas and oil sector (IEA 1993a).

The main objectives of government R\&D were to 1) improve profitability from oil and gas activities, 2) increase energy supply through better use and development of existing and new resources, 3) reduce the environmental impact of the energy sector, and 4) develop new industrial opportunities (IEA 1993a).

Taxes: In 1992, Norway implemented environmental taxes of $\mathrm{NKr} 0.07$ per $0.25 \%$ sulphur on fuel oil. The $\mathrm{CO}_{2}$ tax for fuel oil was $\mathrm{NKr} .47$ per liter. Corporate taxes were $28 \%$ (NKr $=$ US\$0.161) (IEA 1993a).

\section{Crude Oil}

Background: By 1996, Norway expects oil production to be roughly $20 \%$ above the 1991 levels. At current production levels, proven reserves are expected to last 15 years (IEA 1993a).

Government Ownership of Business Entities: Statoil is a wholly owned government company operating as a commercial company. Until recently, Statoil participated in all licenses issued and held a $50 \%$ or more share in all licenses issued since 1979. A portion of the license held by Statoil was held directly by the government through the State's Direct Financial Participation (SDFP). Using this agency, the government directly funded a portion of each license's activities from the State budget. Norsk Hydro, 
the second largest gas and oil company after Statoil, has a $51 \%$ Norwegian government ownership (IEA 1992c). Preferential treatment of Statoil ended about the end of 1992.(a)

Statoil is separate from the SDFP. The SDFP still funds a share of each license. However, Statoil is only the marketing arm for the government's oil. Statoil paid taxes of $\mathrm{NKr} 4.5$ billion in 1993 . $^{\text {(b) }}$

Government Ownership of Natural Resources: All natural resources are owned by the state (IEA 1992c).

Investment and Production Restrictions: Development plans must be approved by the government and companies must demonstrate sufficient expertise and experience. Pipelines require a government license (IEA 1992c). All foreign participation must be through joint ventures with the SDFP. ${ }^{(c)}$

Trade Policies: There are no import controls or tariffs on crude oil (IEA 1992c). There are no export restrictions as long as production is within the development plan (IEA 1992c).

Price Controls: Prices are determined by the market (IEA 1992c).

Subsidies: In the 1991 licensing period, the SDFP provided about $30 \%$ funding for exploration and development activities (IEA 1992c).

Government-Sponsored R\&D: During the last two decades, Norway has developed offshore technology adapted to the conditions on its continental shelf through "goodwill agreements" between oil companies and Norwegian industry and institutes. During 1991, the total funding of oil and gas-related R\&D was nearly NKr 2.06 billion (about US\$332 million) of which the government funding accounted for about $5 \%$ or US\$17 million (IEA 1993a).

Major technology development programs with combined public and private funding have been conducted by the Norwegian Council for Scientific and Industrial Research (NTNF), a Norwegian government entity, on floating platforms; drilling and production; pipe transport (multiphase flow); and introduction and use of natural gas (IEA 1993a).

A prototype support program was started in 1991 and a program on enhanced oil recovery and reservoir technology was launched in 1992. A new program on technology for development of small fields subject to stricter environmental regulations has been planned for 1993 . The Government and research councils have also established a research program aimed at air and marine pollution from oil and gas installations (IEA 1993a).

(a) Personal communications with Gordon Barrows, Barrows and Company, 4/4/94.

(b) Personal communications with Odd Anker Hassel, Cambridge Energy Associates, 4/21/94.

(c) Personal communications with Clem (Clement) Malin, Manager, International Government Relations, Texaco, 4/12/94. 
Taxes: The Norwegian Government collects its share of oil production value through the measures described below.

- Prior to the end of 1992, the government had 50\% ownership of all new production activities (equals state's equity in Statoil, plus the government's direct financial participation through Statoil) (IEA 1993a). Since December 1992, greater flexibility has been given regarding the total state share in each license. Fields before 1992 may have had up to $65 \%$ ownership by Statoil (IEA 1992c).

- There is a $28 \%$ corporate tax, state and municipal taxes, plus a $50 \%$ special tax. Depreciation allowances partially offset the combined $78 \%$ tax rate (IEA 1992c, 1993a).

- There is a royalty on crude oil from fields approved for development before January 1,1986 . The royalty on fields developed before 1972 is $10 \%$, for fields after 1972 (but before 1986) the royalty is 8 to $16 \%$ (IEA 1992c, 1993a).

- In addition, there is an annual capital tax of 0.3\% (IEA 1992c).

- There is a tax of NKr 0.8 per cubic meter $\mathrm{CO}_{2}$ emission on gas burned (IEA 1992c).

\section{Refined Oil}

Government Ownership of Business Entities: Statoil controls about $30 \%$ of the market in refined products. Two private firms also own refineries (IEA 1992c).

Investment and Production Restrictions: There are no investment or production restrictions in the refined oil sector (IEA 1992c).

Distribution Restrictions: There are no distribution restrictions in this sector. There are limits on the lead and sulphur contents of fuel oil (IEA 1992c).

Trade Policies: There are no restrictions on imports or exports and no duties on imports.

Price Controls: The government oversees price changes (IEA 1992c).

Taxes: The 20\% VAT applies to oil products. The VAT is refundable for commercial ventures. There are excise taxes on heavy fuel oil and gasoline. Unleaded gasoline receives favorable excise tax treatment (IEA 1992c). There is a $\mathrm{CO}_{2}$ emissions tax on gasoline, at US\$196 per metric ton of carbon, and on fuel oil, at US\$66 per metric ton. A sulfur tax is also applied to fuel oil. The total tax on fuel oil for 1993 is proposed to be NKr 0.47 per liter (IEA 1993a). 


\section{Natural Gas}

Background: Norway expects to increase natural gas production by about 50\% above 1991 levels by the year 2000. Several natural gas pipelines to Europe have been completed or are being expanded. In December 1992, the 14th round of licensing on the Norwegian continental shelf was announced, including a total of 50 blocks or part blocks. Of these, 25 are in the North Sea, 13 are on the midNorwegian shelf and 12 are in the Barents Sea (IEA 1993a).

Government Ownership of Business Entities: Government ownership for natural gas is the same as for crude oil (IEA 1992c).

Government Ownership of Natural Resources: Government ownership for natural gas is the same as for crude oil (IEA 1992c).

Investment and Production Restrictions: Investment and production restrictions are the same as for crude oil (IEA 1992c). See this section under price controls.

Distribution Restrictions: The government requires a license to build a pipeline (IEA 1992c).

Trade Policies: There are no restrictions regarding who may buy Norwegian gas. The government's stated purpose for directing the marketing of Norwegian gas is that the European market is characterized by a few monopoly buyers of natural gas, while on the supply side, Norway must compete with other large suppliers (IEA 1993a). There are no imports (IEA 1992c).

Price Controls: Statoil leads a consortium called the Norwegian Gas Negotiating Consortium (GFU) which consists of the three domestic production companies: Statoil, Norsk Hydro, and Saga Petroleum. The GFU negotiates the price and other terms, and determines which producers will fulfill the obligations. Thus GFU not only negotiates price, but also coordinates gas production. The government approves all sales agreements. The GFU negotiations do not preclude owners of gas negotiating for their own prices. The government's stated purpose for the GFU is to achieve rational use of resources (IEA 1992a, 1993c).

Government-Sponsored $R \& D$ : For a description of government-sponsored $R \& D$, see the corresponding section above under crude oil (IEA 1992c).

Taxes: For a description of taxes, see the corresponding section above under crude oil (IEA 1992c). There is a $\mathrm{CO}_{2}$ emissions tax on offshore natural gas at $\$ 196$ per metric ton of carbon (IEA 1993a).

\section{Coal}

Government Ownership of Business Entities: The coal company (Store Norske Spitsbergen KullKompani A/S) is $99.94 \%$ owned by the Norwegian government (IEA 1992c). 
Government Ownership of Natural Resources: Coal resources are owned by the government (IEA 1992c).

Investment and Production Restrictions: There are no investment restrictions and no legal restrictions to foreign ownership (IEA 1992c).

Price Controls: There are no price controls (IEA 1992c).

Subsidies: The Norwegian coal company is heavily subsidized by the State (IEA 1992c).

Taxes: There is a $\mathrm{CO}_{2}$ emissions tax on coal of US\$47-70 per metric ton of carbon (IEA 1993a).

\section{Nuclear}

Background: There is no nuclear sector in Norway (IEA 1992c).

\section{Electricity}

Background: Norway's electricity generation is $99 \%$ hydropower (IEA 1992c). Norway has relatively low electricity prices for the OECD countries (IEA 1993a).

Norway has the capacity to transmit $2070 \mathrm{MW}$ to Sweden, $550 \mathrm{MW}$ to Denmark, $50 \mathrm{MW}$ to Finland, and $25 \mathrm{MW}$ to Russia (IEA 1993a).

Government Ownership of Business Entities: Statkraft owns about $30 \%$ of total production capacity. Statnett owns $85 \%$ of the central transmission grid system. Each is a statsforetak--a form of state enterprise that is more independent than a state-administered enterprise. Statnett recently merged with Norwegian Power Pool, which was owned by 110 electricity utilities throughout Norway (IEA 1993a). About 200 locally owned, small, utility companies provide distribution to residential and some industrial consumers. Parliament passed a law in 1990 to make the supply of electricity competitive (IEA 1992c).

Investment and Production Restrictions: The State allocates waterfalls by license. Some industrial companies produce their own electricity (IEA 1992c).

Distribution Restrictions: Statnett SF, a state-regulated and state-owned, but not state-controlled entity, owns $85 \%$ of the transmission lines in Norway (IEA 1992c).

Trade Policies: Both exports and imports of electricity are managed by Statkraft (IEA 1992c). 
Price Controls: Prices for electricity are subject to competition. The distribution and transportation of electricity are subject to monopoly regulation (IEA 1992c).

Currently, Statkraft is collecting fees which are higher than investment and operating costs. However, the ability of consumers to choose the lowest cost producer may force Statkraft to reduce prices (IEA 1992c).

Subsidies: See price controls above.

Government-Sponsored $R \& D$ : Norway's R\&D focuses on improvements in hydropower production, distribution of electricity, energy end-use efficiency, environmentally effective processes and products, and new renewable supply technology. In 1991, the government share of non-oil and gas R\&D was $31 \%$ of the total or about US\$37 million. Program areas include improvement of the electricity system, development of solid oxide fuel cell technology for natural gas, and improvement and promotion of heat pump technology (IEA 1993a).

Taxes: A 20\% VAT applies to final consumption activities. In addition, there is an excise tax on most uses.

\section{Renewable Energy}

Background: One of Norway policies is to develop and establish a Norwegian renewable energy industry (IEA 1993a).

Government-Sponsored $R \& D$ : Energy efficiency investments are exempt from investment tax (IEA 1993a).

The Norwegian Industry Bank provides $20 \%$ of the investment cost to industry investing in energy conservation measures. Investments in energy conservation are tax exempt. The government also provides up to $50 \%$ of the investment cost in prototype and demonstration projects on conservation and efficiency projects (IEA 1992c). 



\title{
United Kingdom
}

\begin{abstract}
All Sectors
Background: The United Kingdom (U.K.) has an abundant supply of oil, natural gas, coal, and an established nuclear industry (IEA 1993a).

Energy Supply: In 1991, the U.K. energy supply was split between oil (38.1\%), natural gas (23.5\%), coal $(29.8 \%)$, and nuclear $(8.5 \%)$, with very little hydropower (less than $1 \%$, most of which is located in Scotland) (IEA 1992c, 1993a).
\end{abstract}

Trade: The U.K. is a net energy exporter (IEA 1992c).

Policies: The Secretary of Energy directs U.K. energy policy (IEA 1992c).

The objectives of energy policy are to 1) develop the U.K. continental shelf energy resources, 2) encourage energy conservation and production efficiency, 3) continue privatization of current stateowned businesses, and 4) promote renewable energy development (IEA 1992c).

Government Ownership of Business Entities: With the exceptions of nuclear power and the coal industry, the U.K. has either privatized or is privatizing the energy sector. Coal is being moved towards privatization.

Energy and the Environment: In 1993, the U.K. raised taxes 8 to $10 \%$ on gasoline and diesel fuel in an attempt to reduce carbon dioxide emissions by $6 \%$, methane by $10 \%$, and nitrous oxide by $75 \%$ by the year 2000. Taxes will reportedly be raised to $5 \%$ above the inflation rate in future years (Knott 1994a; Koen and True 1994b).

In 1990, the public and private industry spent about $0.72 \%$ of the GDP and US\$122 per capita on

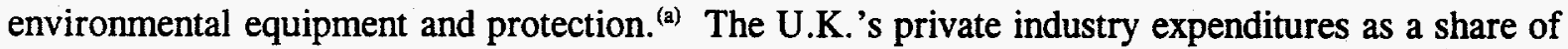
GNP were about $1.0 \%$ in 1990 as compared with $0.86 \%$ for the United States. However, the U.K. figure includes privately owned water treatment, which in all other countries is excluded in public sector figures. The difference between enforcement of environmental regulations between these countries and the United States is relatively wide (OTA 1994). U.K. industry spent about US\$7.0 billion in 1990 on environmental equipment and protection. The OECD expects sales to grow $6.3 \%$ annually to about US\$11.0 billion in the year 2000 (OECD 1992).

(a) Organization for Economic Co-operation and Development (OECD). "Environmental Cost and Industrial Competitiveness." OECD, Paris, France. Restricted document, draft, 5/20/92. 
Government-Sponsored R\&D: Total R\&D reached about US $\$ 235$ million in $1992-93$, or about $0.022 \%$ of the GDP (IEA 1993a). The U.K. has one of the lowest government R\&D budgets among IEA countries (IEA 1992c). The U.K. R\&D expenditures dropped by 6\% from 1990-91 to 1992-93. During 1992-93, a large share of spending was on nuclear technology--nuclear breeders (about US\$91 million) and nuclear fusion (about US\$29 million), though both of these have decreased from the previous period. Government spending on oil and gas recovery is small (less than US\$2 million) and coal is also small (less than US\$8 million) (IEA 1993a). In 1990, over $70 \%$ of all government R\&D funds went to nuclear fission and fusion research. Conservation accounted for $9 \%$ of R\&D spending, oil and gas received just 6\%, and renewable energies 10\% (IEA 1992c).

Taxes: A VAT on residential energy use will rise from 8 to $17.5 \%$ in April 1995. In addition, fuel taxes are to increase $3 \%$ in real terms, in addition to the $10 \%$ increase announced in 1993 (IEA 1993a).

\section{Crude Oil}

Government Ownership of Business Entities: All companies, upstream and downstream, operate in the private sector on a commercial basis. Government involvement is generally restricted to regulation of the market through licensing procedures, environmental and safety controls, and setting the fiscal framework (IEA 1993a).

Government Ownership of Natural Resources: All energy resources belong to the government, whether on land or offshore (IEA 1992c).

Investment and Production Restrictions: Plans for oil exploration are subject to approval by the Secretary of State. License approvals are usually heavily dependent on the plans and upon geological analysis of the area. Pipelines are subject to government approval (IEA 1992c).

Licenses may be approved for a company of any nationality. But awardees must have adequate representation in the U.K. Subsidiaries of foreign companies usually fulfill this requirement. The Monopolies and Mergers Commission can review investment in British companies. The Kuwait Investment Office was forced to reduce their ownership in British Petroleum (BP) to $10 \%$ (IEA 1992c).

Trade Policies: All oil produced on the Continental shelf must be landed in the U.K. This provision is usually waived for EC countries (IEA 1992c). There are no controls on exports and imports and no import tariffs (IEA 1992c).

Price Controls: There are no controls on prices (IEA 1992c).

Government-Sponsored $R \& D$ : Government spending on oil and gas recovery is less than US\$2 million (IEA 1993a). 
Taxes: The Petroleum Revenue Tax (PRT) was revised, in part, to reduce the tax on existing fields from 75 to $50 \%$ and to exempt new fields from the PRT (IEA 1993a). The exemption on new fields applies only to discoveries of 20,000 bd or less. ${ }^{(a)}$ Exploration and development expenses can no longer be deducted from PRT payable. It is expected that the changes in PRT will increase revenue to the Treasury by 1994/95 (IEA 1993a).

\section{Refined Oil}

Government Ownership of Business Entities: Refining enterprises in the U.K. are private (IEA 1992c).

Investment and Production Restrictions: The Monopolies and Mergers Commission can impose investment limits (IEA 1992c). Foreign ownership may be specifically scrutinized (IEA 1992c).

Distribution Restrictions: Pipelines require government approval. There are limits on sulfur and lead contents in fuel oils (IEA 1992c).

Trade Policies: There are no import or export restrictions. Import duties are in line with the General EC Tariff (IEA 1992c).

Price Controls: There are no price controls (IEA 1992c).

Taxes: Refined oil products are subject to a $8 \%$ VAT, which is rising to $17.5 \%$ in 1995 . Commercial enterprises are exempt. There are excise taxes on most fuels. Unleaded gasoline receives favorable excise tax treatment of 4 pence per liter (IEA 1992b, 1992c).

\section{Natural Gas}

Background: There is an import contract between National Power and GFU. There are plans for Statoil of Norway, in a joint venture with Norsk Hydro and British Petroleum, to market gas in the U.K. (IEA 1992b).

Government Ownership of Business Entities: British Gas has 30 competitors for supplying industrial customers (IEA 1993a). British Gas is still the only public gas supplier meeting residential needs. Its competitors can market to entities requiring over 25,000 therms per year. British Gas has also agreed to reduce its industrial and commercial share to $40 \%$ by 1995 (IEA 1992c). In addition, British Gas is being restructured into five separate independent entities over two years, starting in March 1994. They include a transportation and storage division, public gas supply division, industrial supply division, servicing and installation division, and a retail outlet division (Knott 1993).

(a) Personal communications with Gordon Barrows, Barrows and Company, 4/4/94. 
Government Ownership of Natural Resources: All natural gas resources belong to the government whether on land or on the continental shelf (IEA 1992c).

Investment and Production Restrictions: All plans for exploration and development have to be approved by the Secretary of State. Certain requirements need to be met. These requirements are the same as for crude oil and can usually be met by having a subsidiary company in the U.K.. The building of pipelines also requires the approval of the Secretary of State (IEA 1992c). A 15\% share limit is applied to the British Gas special share. Foreign ownership may be reviewed by the Monopolies and Mergers Commission (IEA 1992c).

Distribution Restrictions: The U.K. transportation and distribution network for natural gas is mainly owned by British Gas (IEA 1993a). The British Gas pipeline is open to third parties, given contract agreement. If agreement cannot be reached, the British government will adjudicate. Residential consumers face a British Gas monopoly (IEA 1992c).

Trade Policies: All natural gas found on the Continental Shelf must be landed in the U.K.. This requirement may be waived for EC countries. Intergovernmental treaties would be required to build a pipeline between the U.K. and its neighboring countries. There are no legal restrictions, but British Gas usually consults the government before importing gas. There are no import duties on natural gas. Exports must be approved by the Secretary of State (IEA 1992c).

Price Controls: The are no price controls on wellhead gas. Residential consumers are protected by a tariff schedule. Commercial and industrial consumers, using over 25,000 therms per year, face competitive prices (IEA 1992c).

Subsidies: There are no direct subsidies (IEA 1992c).

Government-Sponsored $R \& D$ : Government spending on oil and gas recovery is less than US\$2 million (IEA 1993a).

Taxes: There is a levy on gas field contracts developed before the PRT was enacted in 1975. The PRT was recently revised, in part, to reduce the tax on existing fields from 75 to $50 \%$ and new fields were exempted. Exploration and development expenses can no longer be deducted from PRT payable (IEA 1993a). A VAT of $17.5 \%$ is applied to all uses, except residential, which is zero, and commercial, which is refundable (IEA 1992c):

\section{Coal}

Background: On March 25th, 1993, the Government published a white paper on the coal industry, after an announcement in 1992 that it would be closing 31 of its 50 deep mines. The white paper said that the government would temporarily subsidize British Coal to give U.K. coal mines an opportunity to improve efficiency and competitiveness. The subsidy was to decline progressively until British Coal 
is privatized. Areas affected by mine closures would be provided 200 million pounds sterling. Support would continue to be provided for new coal technology research and additional funds would be provided to the Coal Research Establishment (IEA 1993a).

Government Ownership of Business Entities: British Coal is a $100 \%$ government-owned company. It may license coal mining to private entities (IEA 1992c). The government is in the process of reducing subsidies to British Coal in order to privatize it. In addition, in 1992, the government decided to sell 13 of British Coal's mines that were going to be abandoned (IEA 1993a).

Government Ownership of Natural Resources: For the most part, British Coal owns all the coal resources in the U.K. (IEA 1992c).

Investment and Production Restrictions: Foreign ownership is prevented by the British Coal monopoly (IEA 1992c).

Trade Policies: Until 1993, imports were limited by guaranteed marketing contracts held by British Coal. Imports will be totally free after the guarantee with Scottish Power expires in 1995. There are no import duties (IEA 1992c). There are no export restrictions (IEA 1992c).

Price Controls: British Coal had guaranteed markets through 1993 with National Power and Powergen, and with Scottish Power until March 1995 (IEA 1992c).

Subsidies: There are government grants covering the restructuring of the British coal industry. As necessary, the government also covers British Coal's monetary shortfalls. In addition, British Coal may borrow directly from the government (IEA 1992c). The U.K. Government made direct payments to British Coal to buy down its accumulated borrowings, which were U.K. $\mathfrak{1} 4.2$ billion through 1990 (Rozenzweig 1993). The U.K. Government will pay consumer subsidies for an undetermined period to encourage consumption of U.K. coal. Covering social security costs is the other major category. British Coal has signed contracts to deliver 40 million metric tons in 1993/94 and 30 million in each of the following four years (IEA 1993a).

Government-Sponsored $R \& D$ : Coal R\&D is being focused on high-efficiency, low-pollution technologies, such as fluidized and integrated-gasification combined cycle (IEA 1992b). Government coal R\&D is about $3 \%$ of the government energy R\&D spending (IEA 1993a).

\section{Nuclear}

Government Ownership of Business Entities: Nuclear Electric is wholly owned by the Government (IEA 1993a). Scottish Nuclear is $100 \%$ state owned. The British government is responsible for all phases of nuclear energy production including fuel manufacture, research, and generation (IEA 1992c). 
Production Restrictions: There is a government-owned monopoly on nuclear power plants (IEA 1992c).

Trade Policies: All nuclear material import and export transactions, including equipment, are subject to government licensing (IEA 1992c).

Subsidies: Nuclear power is subsidized through the nonfossil-fuel levy placed on electricity consumption (IEA 1992c).

Government-Sponsored $R \& D$ : The government pays for almost all of the research done by the United Kingdom Atomic Energy Authority, a government-owned research corporation. Scottish Nuclear has a 15-year contract for its supplies and government guarantees for its liabilities (IEA 1992c).

\section{Electricity}

Government Ownership of Business Entities: There is a mixture of public and private ownership in the U.K. electricity market. However, most of the electricity industry was privatized in 1990 . The generation sector is dominated by three large companies: Powergen, National Power, and Nuclear Electric, in England and Wales. The government retains a $40 \%$ ownership in the first two companies and $100 \%$ ownership in the third. In Scotland, there are two privately integrated companies and one state-owned company. Solely state-owned companies are nuclear. Distribution in England and Wales is privately owned by 12 companies. They jointly own the grid system called the National Grid Company. The 12 companies in England and Wales, and the two integrated companies in Scotland, are called the "public electric supply" (PES) companies (IEA 1992c).

Private generation through cogeneration is encouraged. If more than $51 \%$ of the power generated is used internally, the site may be exempt from licensing (IEA 1992c).

Investment and Production Restrictions: The Secretary of State must approve all new power generation construction and siting. Most approvals require an environmental assessment and some require public hearings (IEA 1992c). The Monopolies and Mergers Commission oversees all foreign investment (IEA 1992c).

Distribution Restrictions: Any entity using less than $1 \mathrm{MW}$ per year must buy from PES companies (see government ownership) until 1994 and then anyone using less than $100 \mathrm{~kW}$ must buy from PES companies. Large users after 1994 may purchase power from anyone subject to a limit of $15 \%$ of Powergen's and National Power's joint capacity. Individual companies may generate their own power, providing it does not exceed $15 \%$ of the grids requirements. The distribution companies are also required to contract at least $20 \%$ of their needs from nonfossil-fuel generation (IEA 1992c).

Trade Policies: There are no controls on either exports or imports and there are no import duties (IEA 1992c). 
Price Controls: Consumers under $1 \mathrm{MW}$ are subject to a government-controlled tariff rate. Customers with under 10-MW-peak use may use the tariff rate or negotiate a contract. Those using over $10 \mathrm{MW}$ must negotiate their price (IEA 1992c).

Subsidies: There are no direct subsidies (IEA 1992c).

Taxes: An $11 \%$ levy is placed on electricity sales in order to cover the added costs of using nonrenewable and biomass electricity generation. Residential customers are commercial users exempt from the VAT. For other consumers, a 17.5\% VAT applies (IEA 1992c).

\section{Renewable Energy}

Background: The Government is working towards $1500 \mathrm{MW}$ of renewable energy electricity generating capacity in the U.K. by 2000 (IEA 1993a).

Investment and Production Restrictions: The non-fossil fuel obligation requires the regional electric companies (RECs) to buy electricity from renewable sources in addition to nuclear generation. Only about $5 \%$ of the non-fossil levy went towards renewables in 1992/93, but the proportion is planned to increase throughout the decade (IEA 1993a).

Distribution Restrictions: See the corresponding section under electricity.

Trade Policies: See the corresponding section under electricity.

Price Controls: See the corresponding section under electricity.

Subsidies: The government has provided funds for surveys of CHP prospects and potential (IEA 1992c).

Government-Sponsored $R \& D$ : Renewable energy receives about $10 \%$ of government $R \& D$ spending (IEA 1992c). 



\section{References}

American Petroleum Institute (API). 1993a. Costs to the Petroleum Industry of Major New and Future Federal Government Environmental Requirements. Discussion Paper \#070R, API, Washington, D.C.

American Petroleum Institute (API). 1993b. Trends in the Geographic Allocation of Upstream Capital and Exploration Expenditures by Leading U.S. Oil Companies, 1981-1992. API, Washington, D.C.

Baker, G. 1994. "New Mexican Taxes to Transform PEMEX Capital Spending Strategy." Oil and Gas Journal 92(3):33-40.

Congressional Budget Office (CBO). 1993. A Budgetary and Economic Analysis of the North American Free Trade Agreement. Government Printing Office, Washington D.C.

Energy Information Administration (EAI). 1992a. Country Profiles: 1992. Energy Information Administration, U.S. Department of Energy, Washington, D.C.

Energy Information Administration (EAI). 1992b. Federal Energy Subsidies: Direct and Indirect Interventions in Energy Markets. Report No. SR/EMEU/92-02, Energy Information Administration, U.S. Department of Energy, Washington, D.C.

Energy Information Administration (EAI). 1993. Country Profiles: 1993: An Energy Overview of Important Countries in the World Oil Market. Energy Information Administration, U.S. Department of Energy, Washington, D.C.

Farmer, R.D. 1993a. Energy and Petrochemicals in the North American Free Trade Agreement. Congressional Budget Office, Washington, D.C.

Farmer, R.D. 1993b. "Energy and Petrochemicals in the North American Free Trade Agreement." Presented at the 15th Annual North American Conference of the International Association for Energy Economics, October 11, 1993, Seattle, Washington.

General Agreement on Tariffs and Trade (GATT). 1993a. Trade Policy Review: Australia. GATT, Geneva, Switzerland.

General Agreement on Tariffs and Trade (GATT). 1993b. Trade Policy Review: Mexico, Vol 1. GATT, Geneva, Switzerland.

Knott, D. (Senior Editor). 1993. "British Gas to Undergo Broad Restructuring." Oil and Gas Journal 91(52):28.

Knott, D. 1994a. "Contrasting approaches to pollution control." Oil and Gas Journal 92(6):39. 
Knott, D. (Senior Editor). 1994b. "DOE plans halt in SPR purchases." Oil and Gas Journal 92(7):39.

Koen, A.D. (Senior Editor-News) and True, W.R. (Pipeline/Gas Processing Editor). 1994a. "Chevron Outlines Ambitious Financial Objective." Oil and Gas Journal 92(6):32.

Koen, A.D. (Senior Editor, News) and True, W.R., (Pipeline/Gas Processing Editor). 1994b. "World Pipeline Construction to Slip for 1994 and Beyond." Oil and Gas Journal 92(6):23-31.

Levine, P.J. 1991. "U.S. Anti-Bribery Law: Setting Boundaries for Business Conduct." Business Korea 8(9):31-32.

Oil and Gas Journal (OGJ). 1994a. "Crippling Burden Seen in OPA." Oil and Gas Journal 92(1):22-23.

Oil and Gas Journal (OGJ). 1994b. "OGJ Newsletter." Oil and Gas Journal 92(3):2-4.

International Energy Agency (IEA). 1992a. Electricity Supply in the OECD. Report No. 6191201 , Organization for Economic Cooperation and Development, Paris, France.

International Energy Agency (IEA). 1992b. Energy Policies of IEA Countries: 1991 Review. Report No. 619213 1, Organization for Economic Cooperation and Development, Paris, France.

International Energy Agency (IEA). 1993a. Energy Policies of IEA Countries: 1992 Review. Report No. 619315 1, Organization for Economic Cooperation and Development, Paris, France.

International Energy Agency (IEA). 1993b. Energy Statistics and Balances of Non-OECD Countries, 1990-1991. Report No. 619313 3, Organization for Economic Cooperation and Development, Paris, France.

International Energy Agency (IEA). 1992c. The Role of IEA Governments in Energy: A Survey. Report No. 619212 1, Organization for Economic Cooperation and Development, Paris, France.

Organization for Economic Co-operation and Development (OECD). 1992. The OECD Environment Industry: Situation, Prospects and Government Policies. Report No. OCDE/GD(92)1, OECD, Paris, France.

Rozenzweig, R.H. 1993. "The Energy Bill." Public Utilities Fortnightly. January 1, 1993.

Singer, A.W. 1991. "Ethics: Are Standards Lower Overseas." Across the Board 28(9):31-34. 
Stanberry, K., George B.C., and Ross M. 1991. "Securities Fraud in the International Arena: Unilateral vs. Multilateral Enforcement of Insider Trading Sanctions." Business and Society 30(1):27-36.

U.S. Congress, Office of Technology Assessment (OTA). 1994. Industry, Technology, and the Environment: Competitive Challenges and Business Opportunities . Report No. OTA-ITE-586, U.S. Government Printing Office, Washington, D.C.

U.S. Department of Commerce and U.S. Department of Interior (DOC and DOI): 1988. A Cost Comparison of Selected U.S. and Canadian Coal Mines. DOI and DOC, Washington, D.C.

U.S. Department of Energy (DOE). 1993. The U.S. Petroleum Industry: Past as Prologue, 19701992. Report No. DOE/EIA-0572, DOE, Washington, D.C.

U.S. Department of Energy (DOE) 1994. Energy Company Competitiveness: Little To Do With Subsidies. Report No. not assigned, DOE, Washington, D.C.

U.S. Department of Interior (DOI). 1993. A Cost Comparison of Selected Coal Mines From Australia, Canada, Colombia, South Africa, and the United States. DOI, Washington, D.C.

U.S. Department of State (DOS). 1994. Patterns of Global Terrorism 1993. Department of State publication number 10136, DOS, Washington, D.C.

U.S. International Trade Commission (USITC). 1993. Potential Impact on the U.S. Economy and Selected Industries of the North American Free-Trade Agreement. Publication 2596, USITC, Washington, D.C. 



\section{Telephone or Fax Interviewees}

Austin, Ken. International Economist, Syria, Iraq, Iran, Yemen, and Jordan Desk, U.S. Department of Treasury, 3/6/94.

Barrows, Gordon. Barrows Company, 4/4/94, 4/6/94.

Beck, Bob. Economics Editor, Oil and Gas Journal, 3/30/94.

Bhattacharjee, Kumar. An independent oil and gas explorer, 4/12/93.

Blok, Kornelis. Professor, Department of Science, Technology, and Society, Utrecht University, The Netherlands, 3/24/94.

Bower, Dr. Len. Chief Economist, American Petroleum Institute, 5/13/94.

Bowers, Jaime. Public Affairs Officer, Independent Petroleum Association of America, 3/18/94.

Burns, Tom. Economist, Chevron U.S.A., Inc., 3/30/94.

Burton, Elizabeth. Tax Council, State Income and Tax Excise, Chevron U.S.A., Inc., 3/30/94.

Campbell, Jim. Director, Economic Analysis, Energy Policy Branch, Natural Resources Canada, 3/29/94.

Coburn, Leonard. Acting Director, Office of Oil and Natural Gas, Department of Energy, 3/30/94.

Dozier, Dow. Associate Director of Communications, Kerr-McGee Co. 3/24/94.

Eis, Don. Deputy Assistant Trade Representative for Industry, U.S. Trade Representative, 4/7/94.

Gallogly, Steve. Chief of Energy Producer Country Affairs, Office of International Policy, U.S. Department of State, 3/22/94.

Gillett, Thomas. Oil and Gas Analyst, U.S. Department of Commerce, 3/18/94.

Guey-Lee, Louise. Environmental Economist, Coal Mining, Energy Information Administration, U.S. Department of Energy, 5/11/94.

Gunn, Betsy. Congressional Office of Technology Assessment, 5/12/94.

Guy, John. Deputy Executive Director, National Petroleum Council, 5/12/94. 
Harrer, Bob. Coordinator of Policy Development, Chevron U.S.A., Inc. 3/29/94.

Hassel, Odd Anker. Cambridge Energy Associates, 4/21/94.

Lizarraga, Jaime. U.S. House Committee on Energy and Commerce, Subcommittee on Oversight and Investigations, 3/22/94.

Malin, Clement (Clem). Manager, International Government Relations, Texaco, 4/12/94.

McCall, Louis. Economics Officer, Bureau of South Asian Affairs, U.S. Department of State, $3 / 14 / 94$.

McLauglin, Susan. Monitoring Unit, Economic and Financial Analysis, Natural Resources Canada, $3 / 30 / 94$.

North, Steve. Public Affairs, Chevron U.S.A., Inc., 3/30/94.

O’Brien, Dennis. Chief Economist, Caltex, 3/31/94.

Oddenino, Chuck. Program Manager, Coal Recoverability, International Coal Cost Comparison Program, Bureau of Mines, U.S. Department of Interior, 5/12/94.

Phelleps, Amoya. Vice President, Coal Exporters Association, 3/29/94.

Rase, Glen. Director, Office of Global Energy, Office of International Policy, U.S. Department of State, $3 / 24 / 94$.

Rasmussen, John. International Trade Administration, Energy Office, Trade Specialist, U.S. Department of Commerce, 3/22/94.

Rypinski, Arthur. Petroleum and Refining, Energy Information Administration, U.S. Department of Energy, 5/11/94.

Spiller, Reginald. Deputy Assistant Secretary for Natural Gas and Petroleum, U.S. Department of Energy, 4/4/94.

Stanley, Norm. Public Affairs Manager for Washington State, Texaco. 3/30/94.

Tippee, Bob. Managing Editor, Economics and Exploration, Oil and Gas Journal, 3/31/94.

Waddington, Ed. Department of Finance, Canada, 3/30/94.

Wiley, Tom. Vice President, Governmental Relations, Sun Company Inc., 5/18/94. 
Appendix A 
Table A.1. Energy Sector Production, Trade, and Consumption by Country in 1991

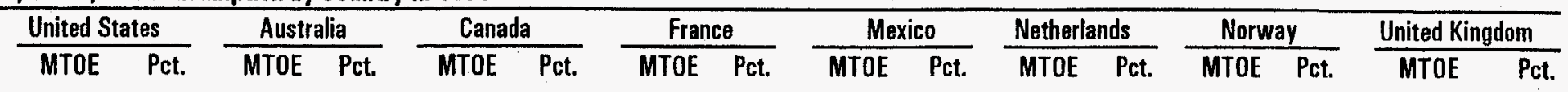

\section{Production}

Oil

Gas

Coal

Nuclear

Hydro

Geothermal

Solar/wind

Other solid fuels

Total Production

\begin{tabular}{l} 
Trade \\
\hline Oil \\
-. Exports \\
-. Imports \\
- Bunkers \\
-. Net imports \\
Gas \\
-. Exports \\
-- Imports \\
- Net imports \\
Coal \\
-. Exports \\
-- Imports \\
- Net imports \\
Electricity \\
-. Exports \\
-- Imports \\
-- Net imports \\
\hline
\end{tabular}

Total Net Imports

$\begin{array}{rrrr}424 & 25.9 & 28.3 & 17.0 \\ 416 & 25.4 & 18.1 & 10.9 \\ 517 & 31.6 & 114.2 & 68.7 \\ 169 & 10.3 & 0 & 0.0 \\ 23 & 1.4 & 1.3 & 0.8 \\ 13 & 0.8 & 0 & 0.0 \\ 0 & 0.0 & 0 & 0.0 \\ 75.0 & 4.6 & 4.4 & 2.6\end{array}$

$\overline{1637.0}$

\section{6}

\subsection{0}

29.0

316.0

3.0

41.0

38.0

69.0

3.0

$-66.0$

1.0

3.0

2.0

290.0

11.0
13.7
0.6
2.1

56.5
35.4
0.7

$-21.8$

4.0

0.0

$-4.0$

38.8

0.3

$-38.5$

73.5

0.0

.73 .5

0.0

0.0

0.0

.75 .4

23.5

8.4
.15 .1

21

0.5

$-1.6$

.77 .0

$\begin{array}{rrrrrr}94.8 & 33.0 & 3.7 & 3.4 & 158.7 & 81.5 \\ 94.9 & 33.1 & 2.7 & 2.5 & 25.3 & 13.0 \\ 39.7 & 13.8 & 7.9 & 7.2 & 3.2 & 1.6 \\ 22.1 & 7.7 & 86.3 & 78.8 & 1.1 & 0.6 \\ 26.5 & 9.2 & 4.9 & 4.5 & 6.5 & 3.3 \\ 0 & 0.0 & 0 & 0.0 & 0 & 0.0 \\ 0 & 0.0 & 0 & 0.0 & 0 & 0.0 \\ 8.9 & 3.1 & 4.0 & 3.7 & 0.0 & 0.0\end{array}$

$\frac{1}{286.9}$

109.5

194.8

\begin{tabular}{rr}
3.8 & 5.7 \\
61.7 & 92.6 \\
0 & 0.0 \\
0.9 & 1.4 \\
0 & 0.0 \\
0 & 0.0 \\
0 & 0.0 \\
0.2 & 0.3 \\
\hline
\end{tabular}

66.6

$\overline{130.5}$

213.8

$\begin{array}{r}14.6 \\ 107.5 \\ 2.6 \\ 90.3 \\ 0.5 \\ 26.2 \\ 25.7 \\ \\ 0.7 \\ 14.8 \\ 14.1 \\ \\ 5.0 \\ 0.5 \\ .4 .5 \\ \hline\end{array}$

125.6

77.2
6.6
0.4

$$
.71 .0
$$

1.6
0.0

0.0

$-1.6$

0.0

$$
0.1
$$

0.1

0.2

0.1

0.1
-0.2

.72 .7

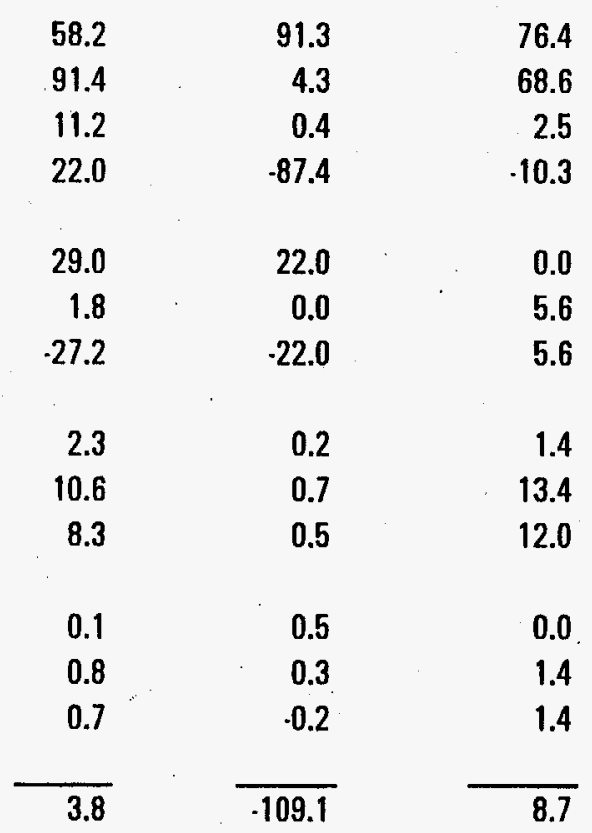




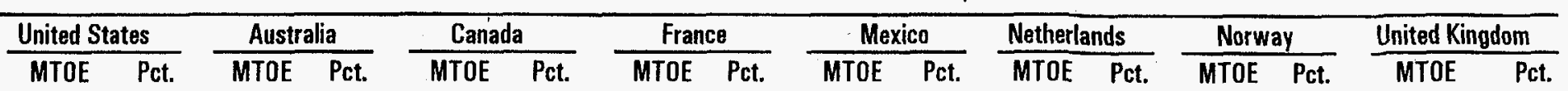

Total Stock Changes

Primary Energy Supply

oil

Gas

Coal

Nuclear

Hydro

Geothermal

Solar/wind

Other solid fuels

Electricity trade

Total Primary Energy
$-0.4$

$\begin{array}{rr}743.0 & 38.4 \\ 460.0 & 23.8 \\ 449.0 & 23.2 \\ 169.0 & 8.7 \\ 23.0 & 1.2 \\ 13.0 & 0.7 \\ 0.0 & 0.0 \\ 74.0 & 3.8 \\ 2.0 & 0.1\end{array}$

1933.0

$\begin{array}{rr}30.8 & 34.0 \\ 14.1 & 15.6 \\ 39.9 & 44.1 \\ 0.0 & 0.0 \\ 0.0 & 0.0 \\ 1.3 & 1.4 \\ 0.0 & 0.0 \\ 4.4 & 4.9 \\ 0.0 & 0.0\end{array}$

90.5
1.9

$\begin{array}{rr}73.6 & 34.7 \\ 56.7 & 26.8 \\ 25.6 & 12.1 \\ 22.1 & 10.4 \\ 26.5 & 12.5 \\ 0.0 & 0.0 \\ 0.0 & 0.0 \\ 8.9 & 4.2 \\ -1.6 & -0.8\end{array}$

211.8
$-2.8$

$92.2 \quad 39.7$

$28.0 \cdots 12.1$

$21.4 \quad 9.2$

$86.3 \quad 37.2$

$\begin{array}{ll}4.9 & 2.1\end{array}$

$0.0 \quad 0.0$

$0.0 \quad 0.0$

$4.0 \quad 1.7$

$.4 .5 \quad .1 .9$

232.3
0.2

$\begin{array}{rr}87.5 & 69.9 \\ 26.7 & 21.3 \\ 3.5 & 2.8 \\ 1.1 & 0.9 \\ 6.5 & 5.2 \\ 0.0 & 0.0 \\ 0.0 & 0.0 \\ 0.0 & 0.0 \\ -0.1 & -0.1\end{array}$

125.2
.0 .5

$25.6 \quad 36.6$

$\begin{array}{ll}34.4 & 49.1\end{array}$

$8.1 \quad 11.6$

$0.9 \quad 1.3$

$0.0 \quad 0.0$

$0.0 \quad 0.0$

$\begin{array}{ll}0.0 & 0.0\end{array}$

$0.2 \quad 0.3$

$\begin{array}{ll}0.8 & 1.1\end{array}$

70.0

21.7

218.1

\section{Energy Intensity Measures}

\begin{tabular}{|c|c|c|c|c|c|c|c|c|}
\hline TPES/ GDP & 0.43 & 0.49 & 0.54 & 0.38 & 0.79 & 0.46 & 0.34 & 0.42 \\
\hline TFC/GDP & 0.30 & 0.32 & 0.40 & 0.25 & 0.57 & 0.37 & 0.28 & 0.29 \\
\hline TPESIPOPULATION $1 /$ & 7.65 & 5.22 & 7.84 & 4.07 & 1.58 & 4.64 & 5.10 & 3.80 \\
\hline TFCI POPULATION 1$]$ & 5.41 & 2.89 & 5.84 & 2.68 & 1.04 & 3.68 & 4.17 & 2.95 \\
\hline
\end{tabular}

1/ TOE or matric ton oil equivalent $=10,000,000 \mathrm{kcal}$

TPES = Total Primary Energy Supply

TFC = Total Final Consumption

MTOE - Million metric tons oil equivalent

Source: IEA 1993a and IEA 1993b. 


$\frac{\text { Germany }}{\text { MTOE Pct. }} \frac{\text { Japan }}{\text { MTOE Pct. }}$

Production

\begin{tabular}{lrrrrr}
\hline Oil & & 4.2 & 2.5 & 0.8 & 1.1 \\
Gas & 13.5 & 8.1 & 0.1 & 0.1 \\
Coal & & 106.1 & 63.8 & 4.4 & 6.0 \\
Nuclear & 38.4 & 23.1 & 55.6 & 76.4 \\
Hydro & 1.3 & 0.8 & 8.4 & 11.5 \\
Geothermal & 0.0 & 0.0 & 1.5 & 2.1 \\
Solar/wind & 0.0 & 0.0 & 0.0 & 0.0 \\
Other solid fuels & 2.7 & 1.6 & 0.1 & 0.1 \\
& & & &
\end{tabular}

Total Production $\overline{166.3} \quad \overline{72.8}$

Trade

Oil

.. Exports

8.8

- Imports

265.1

.. Bunkers

$\begin{array}{rr}140.5 & 265.1 \\ 2.1 & 5.7\end{array}$

- Net imports

129.5

250.6

Gas

$\begin{array}{lrr}\text { - Exports } & 0.9 & 0.0 \\ \text { - Imports } & 44.3 & 44.5\end{array}$

.. Net imports

$43.4 \quad 44.5$

Coal

- Exports

- Imports

- Net imports

Electricity

-- Exports

- Imports

-Net imports

$\begin{array}{ll}4.6 & 1.7\end{array}$

$11.8 \quad 73.6$

$7.1 \quad 72.0$

$2.7 \quad 0.0$

$2.6 \quad 0.0$

$0.0 \quad 0.0$

Total Net Imports $\quad \overline{180.0} \quad \overline{367.2}$ 
Table A.1. (continued) Table A.1. (continued)

$\frac{\text { Germany }}{\text { MTOE Pct. }} \frac{\text { Japan }}{\text { MTOE Pct. }}$

Total Stock Changes

Primary Energy Supply

\section{Oil}

Gas

Coal

Nuclear

Hydro

Geothermal

Solar/wind

Other solid fuels

Electricity trade

\section{Total Primary Energ}

$132.6 \quad 38.2$

$57.7 \quad 16.6$

$114.7 \quad 33.0$

$38.4 \quad 11.1$

$\begin{array}{ll}1.3 & 0.4\end{array}$

$\begin{array}{ll}0.0 & 0.0\end{array}$

$\begin{array}{ll}0.0 & 0.0\end{array}$

$2.7 \quad 0.8$

$\begin{array}{ll}0.0 & 0.0\end{array}$

$249.7 \quad 57.0$

$\begin{array}{ll}46.4 & 10.6\end{array}$

$\begin{array}{ll}76.6 & 17.5\end{array}$

$\begin{array}{rr}55.6 & 12.7\end{array}$

$8.4 \quad 1.9$

$\begin{array}{ll}1.5 & 0.3\end{array}$

$\begin{array}{ll}0.0 & 0.0\end{array}$

$\begin{array}{ll}0.1 & 0.0\end{array}$

$0.0 \quad 0.0$
438.4

0.14

3.54

2.46 


\begin{tabular}{|c|c|c|c|c|c|c|c|c|}
\hline \multicolumn{9}{|c|}{ Table A. 2. Government Policies in Various Energy Sectors of the United States } \\
\hline & & ......01L- & $\ldots$ & & & & & \\
\hline POLICIES & ALL SECTORS & CRUDE & REFINED & NATURAL gas & COAL & NUCLEAR & ELECTRICITY & $\begin{array}{l}\text { RENEWABLE } \\
\text { ENERGY } \\
\end{array}$ \\
\hline \multicolumn{9}{|l|}{ GOVERNMENT OWNERSHIP } \\
\hline -natural resources & & $\begin{array}{l}\text { Owned by } \\
\text { Landowner } \\
\text { unless previously } \\
\text { severed }\end{array}$ & & $\begin{array}{l}\text { Owned by } \\
\text { Landowner } \\
\text { unless previously } \\
\text { severed }\end{array}$ & $\begin{array}{l}\text { Owned by } \\
\text { Landowner } \\
\text { unless previously } \\
\text { severed }\end{array}$ & $\begin{array}{l}\text { Mining is private } \\
\text { but Uranium is } \\
\text { carefully } \\
\text { controlled }\end{array}$ & & \\
\hline . business entitities & & Private & Private & Private & Private & Privately owned & $\begin{array}{l}\text { Mixed-Private } \\
\text { and Government, } \\
\text { but mostly } \\
\text { private }\end{array}$ & Private \\
\hline \multicolumn{9}{|l|}{ INVESTMENT POLICIES } \\
\hline .- foreign ownership restrictions & & $\begin{array}{l}\text { Reviewed if over } \\
5 \%\end{array}$ & $\begin{array}{l}\text { Reviewed if over } \\
5 \%\end{array}$ & $\begin{array}{l}\text { Reviewed if over } \\
5 \%\end{array}$ & $\begin{array}{l}\text { Reviewed if over } \\
5 \%\end{array}$ & Prohibited. & $\begin{array}{l}\text { Reviewed if over } \\
5 \%\end{array}$ & \\
\hline .. production restrictions & $\begin{array}{l}\text { Development of } \\
\text { resources in Alaska } \\
\text { North Slope, Artic } \\
\text { National Wildlife } \\
\text { Refuge, and parts of } \\
\text { Outer Continental } \\
\text { Shelf prohibited } \\
\end{array}$ & $\begin{array}{l}\text { State laws may } \\
\text { restrict } \\
\text { production. }\end{array}$ & & $\begin{array}{l}\text { State laws may } \\
\text { restrict } \\
\text { production. }\end{array}$ & $\begin{array}{l}\text { Subject to } \\
\text { environmental } \\
\text { regulations }\end{array}$ & $\begin{array}{l}\text { Siting and Waste } \\
\text { restrictions have } \\
\text { effectively } \\
\text { stopped new } \\
\text { plants }\end{array}$ & Highly regulated & . \\
\hline - distribution restrictions & & $\begin{array}{l}\text { Jones Act .: } \\
\text { Crude on US flag } \\
\text { ships between } \\
\text { US ports. }\end{array}$ & & & $\begin{array}{l}\text { Jones Act - Coal } \\
\text { on US flagged } \\
\text { ships between } \\
\text { US ports. }\end{array}$ & \begin{tabular}{|l} 
Transport of \\
Uranium strictly \\
controlled.
\end{tabular} & $\begin{array}{l}\text { None, third party } \\
\text { access allowed }\end{array}$ & \\
\hline
\end{tabular}




\begin{tabular}{|c|c|c|c|c|c|c|c|c|}
\hline \multicolumn{9}{|l|}{ Table A. 2. (continued) } \\
\hline & & \multirow{2}{*}{\multicolumn{2}{|c|}{$\ldots . . .011 \ldots . . .}}$. & & & & & \\
\hline & & & & & & & & \\
\hline POLICIES & ALL SECTORS & CRUDE & REFINED & NATURAL GAS & COAL & NUCLEAR & ELECTRICITY & \begin{tabular}{|l|}
$\begin{array}{l}\text { REMEWABLE } \\
\text { ENERGY }\end{array}$ \\
\end{tabular} \\
\hline \multicolumn{9}{|l|}{ TRADE POLICIES } \\
\hline -- import restrictions & & Small tariffs & Small tariffs & $\begin{array}{l}\text { Regulated by } \\
\text { govt. }\end{array}$ & & & $\begin{array}{l}\text { No tariffs, } \\
\text { licenses required. }\end{array}$ & \\
\hline . export restrictions & & $\begin{array}{l}\text { Must be licensed. } \\
\text { Export of Alaska } \\
\text { crude prohibited. }\end{array}$ & $\begin{array}{l}\text { Must be licensed. } \\
\text { Export of Alaska } \\
\text { crude prohibited. }\end{array}$ & Must be licensed. & & & $\begin{array}{l}\text { Licenses } \\
\text { required, but } \\
\text { formality. }\end{array}$ & \\
\hline -. export assistance & & Yes & Yes & Yes & Yes & & & \\
\hline PRICE CONTROLS & & None & None & $\begin{array}{l}\text { Local monopoly } \\
\text { suppliers are } \\
\text { regulated }\end{array}$ & None & & Regulated & \\
\hline SUBSIDIES & $\begin{array}{l}\text { U.S government } \\
\text { provided } \$ 4.9 \text { billion } \\
\text { in direct and indirect } \\
\text { subsidies to the } \\
\text { energy sector }\end{array}$ & & & & & & & . \\
\hline \multicolumn{9}{|c|}{.- payments to producers } \\
\hline - tax incentives & & $\begin{array}{l}\text { Tax relief for } \\
\text { independent gas } \\
\text { and oil producers. } \\
\text { Oil production } \\
\text { has a depletion } \\
\text { allowance. } \\
\end{array}$ & 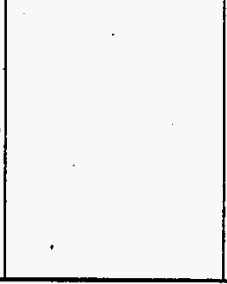 & $\begin{array}{l}\text { Producers can } \\
\text { claim a depletion } \\
\text { allowance. }\end{array}$ & $\begin{array}{l}\text { Producers can } \\
\text { claim an } 8 \\
\text { percent depletion } \\
\text { allowance. }\end{array}$ & & & $\begin{array}{l}\text { Tax credits for } \\
\text { renewable energy } \\
\text { investment }\end{array}$ \\
\hline
\end{tabular}




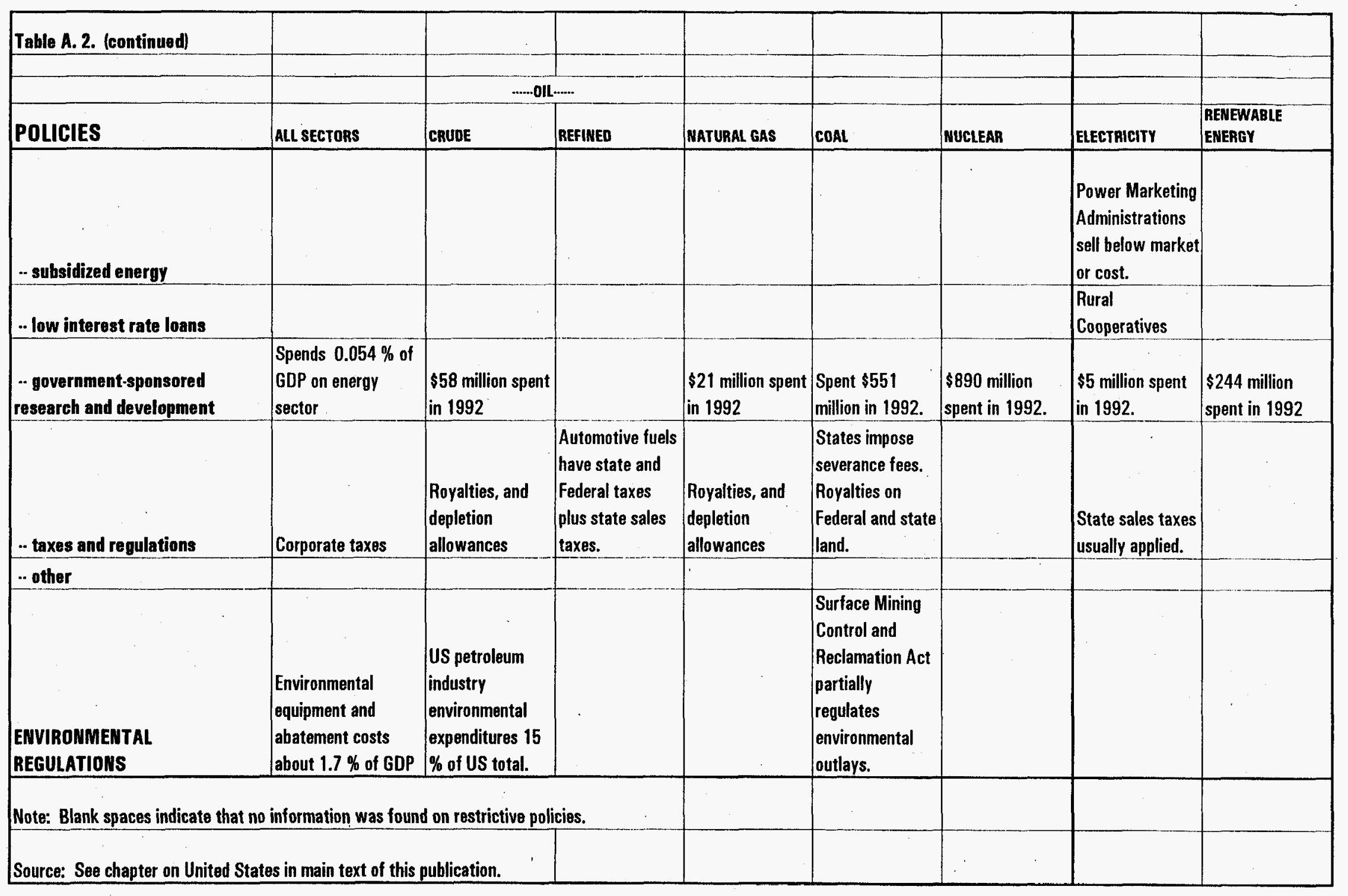




\begin{tabular}{|c|c|c|c|c|c|c|c|c|}
\hline \multicolumn{9}{|c|}{ Table A.3. Government Policies in Various Energy Sectors of Australia } \\
\hline & & \multicolumn{2}{|c|}{$\ldots . .011 \ldots . . .}$. & & & & \multirow[b]{2}{*}{ ELECTRICITY } & \multirow[b]{2}{*}{$\begin{array}{l}\text { RENEWABLLE } \\
\text { ENERGY } \\
\end{array}$} \\
\hline POLICIES & ALI SECTORS & CRUDE & REFINED & NATURAL GAS & COAL & MUCLEAR & & \\
\hline \multicolumn{9}{|l|}{ GOVERNMENT OWNERSHIP } \\
\hline .. natural resources & $\begin{array}{l}\text { Owned by States, } \\
\text { beyond } 3 \text { miles } \\
\text { owned by } \\
\text { Commonwealth }\end{array}$ & & & & & $\begin{array}{l}\text { Uranium owned } \\
\text { by states }\end{array}$ & & \\
\hline -- business entitities & & Private & Private & $\begin{array}{l}\text { Distribution } \\
\text { entities owned by } \\
\text { states. }\end{array}$ & $\begin{array}{l}\text { Mixed - private } \\
\text { and state }\end{array}$ & No program & $\begin{array}{l}\text { State owned .- } \\
\text { moving to } \\
\text { privatization }\end{array}$ & Private \\
\hline \multicolumn{9}{|l|}{ INVESTMENT POLICIES } \\
\hline .- foreign ownership restrictions & & $\begin{array}{l}\text { Investment }> \\
\text { A } \$ 10 \text { million } \\
\text { subject to govt. } \\
\text { scrutiny }\end{array}$ & & \begin{tabular}{|l} 
Investment > \\
A $\$ 10$ million \\
subject to govt. \\
scrutiny
\end{tabular} & $\begin{array}{l}\text { Investment > } \\
\text { A } 10 \text { million } \\
\text { subject to govt. } \\
\text { scrutiny, plus } 50 \\
\text { percent } \\
\text { Australian } \\
\text { ownership }\end{array}$ & & Prohibited & \\
\hline - production restrictions & & $\begin{array}{l}\text { Bidding system } \\
\text { for licenses }\end{array}$ & & $\begin{array}{l}\text { Bidding system } \\
\text { for licenses }\end{array}$ & & & & \\
\hline - distribution restrictions & & & & $\begin{array}{l}\text { Distributors hold } \\
\text { monopoly but } \\
\text { third party sales } \\
\text { allowed }\end{array}$ & & & Owned by states & \\
\hline \multicolumn{9}{|l|}{ TRADE POLICIES } \\
\hline .. import restrietions & & None & $\begin{array}{l}\text { Tariff equal to } \\
\text { excise tax }\end{array}$ & None & & & & \\
\hline - export restrictions & & None & & None & $\begin{array}{l}\text { Settlements } \\
\text { subject to } \\
\text { government } \\
\text { approval } \\
\end{array}$ & & & \\
\hline .. export assistance & Yes & & & & & & & \\
\hline
\end{tabular}




\begin{tabular}{|c|c|c|c|c|c|c|c|c|}
\hline \multicolumn{9}{|l|}{ Table A.3. (continued) } \\
\hline & & & & & & & & \\
\hline & & \multicolumn{2}{|c|}{$-011-$} & \multirow[b]{2}{*}{ MATURAL GAS } & \multirow[b]{2}{*}{ COAL } & \multirow[b]{2}{*}{ NUCLEAR } & \multirow[b]{2}{*}{ ELECTRICITY } & \multirow[b]{2}{*}{$\begin{array}{l}\text { RENEWABLE } \\
\text { ENERGY }\end{array}$} \\
\hline POLICIES & ALL SECTORS & CRUDE & REFINED & & & & & \\
\hline PRICE CONTROLS & & None & Ceilings on prices & None & $\begin{array}{l}\text { Queensland } \\
\text { controls prices. }\end{array}$ & & $\begin{array}{l}\text { Set by state } \\
\text { commisions }\end{array}$ & \\
\hline SUBSIDIES & & None & $\begin{array}{l}\text { Consumer freight } \\
\text { subsidy in remote } \\
\text { areas }\end{array}$ & $\begin{array}{l}\text { Consumer } \\
\text { subsidies }\end{array}$ & & & $\begin{array}{l}\text { Large commercial } \\
\text { users, } \\
\text { pensioners, and } \\
\text { remote areas }\end{array}$ & \\
\hline \multicolumn{9}{|l|}{-. payments to producers } \\
\hline$-x$ tax incentives & & $\begin{array}{l}150 \% \text { tax } \\
\text { deductibility on } \\
\text { R\&D }\end{array}$ & & $\begin{array}{l}150 \% \text { tax } \\
\text { deductibility on } \\
\text { R\&D. }\end{array}$ & $\begin{array}{l}150 \% \text { tax } \\
\text { deductibility on } \\
\text { R\&D }\end{array}$ & & & Yes \\
\hline \multicolumn{9}{|l|}{. subsidized energy } \\
\hline \multicolumn{9}{|l|}{ - low interest rate loans } \\
\hline $\begin{array}{l}\text { - government-sponsored } \\
\text { research and development }\end{array}$ & $\begin{array}{l}\text { Govt. spend } 0.31 \% \\
\text { of GDP in } 1989 / 90\end{array}$ & & & & & & & Yes \\
\hline .- taxes and regulations & . & $\begin{array}{l}\text { Commonwealth } \\
\text { and state } \\
\text { royalties, and } \\
\text { federal excise } \\
\text { taxes }\end{array}$ & $\begin{array}{l}\text { Commonwęalth } \\
\text { and Federal } \\
\text { excise taxes }\end{array}$ & $\begin{array}{l}\text { Resource Rent } \\
\text { Tax - about } 10 \text { - } \\
12.5 \% \text { plus } \\
\text { certain state } \\
\text { consumption } \\
\text { taxes. }\end{array}$ & $\begin{array}{l}\text { Commonwealth } \\
\text { excise tax }\end{array}$ & & No taxes & \\
\hline . other & & & & & & & & \\
\hline
\end{tabular}




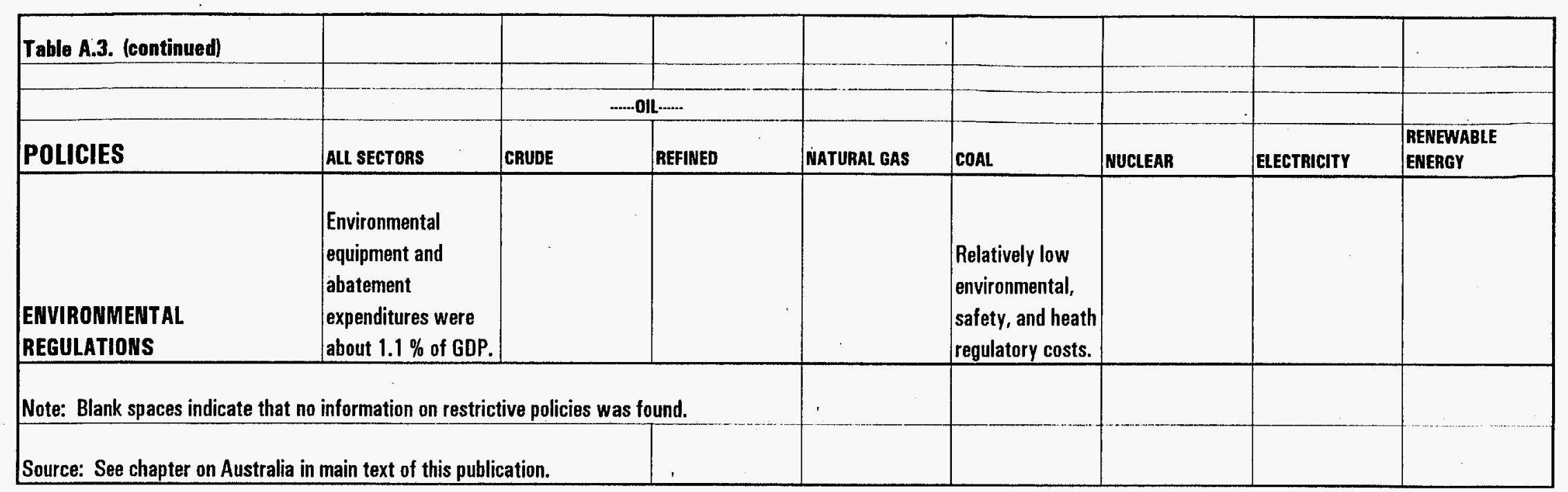




\begin{tabular}{|c|c|c|c|c|c|c|c|c|}
\hline \multicolumn{9}{|c|}{ Table A.4. Government Policies in Various Energy Sectors of Canada } \\
\hline & & \multicolumn{2}{|c|}{$\ldots . . .014 \ldots . . . .}$. & & & & & \\
\hline POLICIES & ALL SECTORS & CRUDE & REFINED & NATURAL GAS & COAL & NUCLEAR & ELECTRICITY & $\begin{array}{l}\text { RENEWABLE } \\
\text { ENERGY } \\
\end{array}$ \\
\hline \multicolumn{9}{|l|}{ GOVERNMENT OWNERSHIP } \\
\hline - natural resources & $\begin{array}{l}\text { Government or } \\
\text { provincially owned }\end{array}$ & & & & & $\begin{array}{l}\text { Uranium owned } \\
\text { by Provinces }\end{array}$ & & \\
\hline - business entitities & & $\begin{array}{l}\text { mixed--going } \\
\text { private }\end{array}$ & $\begin{array}{l}\text { mixed-going } \\
\text { private }\end{array}$ & $\begin{array}{l}\text { mixed-going } \\
\text { private }\end{array}$ & mixed & mixed & $\begin{array}{l}\text { Provincially } \\
\text { owned }\end{array}$ & \\
\hline -. further detail & & - & & & $\begin{array}{l}\text { Nova Scotia and } \\
\text { New Brunswick } \\
\text { have govt. and } \\
\text { prov. owned } \\
\text { mines }\end{array}$ & & $\begin{array}{l}\text { Exceptions: } \\
\text { Prince Edward } \\
\text { Island and } \\
\text { Alberta, utilities } \\
\text { privately owned } \\
\end{array}$ & \\
\hline \multicolumn{9}{|l|}{ INVESTMENT POLICIES } \\
\hline .. foreign ownership restrictions & & $\begin{array}{l}\text { C } \$ 150 \text { million } \\
\text { threshold for U.S. } \\
\text { firms, } \$ 5 \text { million } \\
\text { for others. }\end{array}$ & None & $\begin{array}{l}\text { C } \$ 150 \text { million } \\
\text { threshold for U.S. } \\
\text { firms, } \$ 5 \text { million } \\
\text { for others. }\end{array}$ & $\begin{array}{l}\text { Yes- }-50 \% \text { foreign } \\
\text { threshold }\end{array}$ & $\begin{array}{l}\text { Yes-49\% foreign } \\
\text { threshold }\end{array}$ & Yes & \\
\hline - production restrictions & . & $\begin{array}{l}\text { Provinces } \\
\text { determine } \\
\text { production limits }\end{array}$ & $\begin{array}{l}\text { Prince Edward } \\
\text { Island restricts } \\
\text { consumer outlets }\end{array}$ & $\begin{array}{l}\text { Provinces } \\
\text { determine } \\
\text { production limits }\end{array}$ & & Licensing & $\begin{array}{l}\text { Independent } \\
\text { generators } \\
\text { restricted to } \\
\text { selling to utilities }\end{array}$ & \\
\hline -distribution restrictions & & & $\begin{array}{l}\text { Pipelines } \\
\text { regulated by } \\
\text { provinces }\end{array}$ & $\begin{array}{l}\text { Pipelines } \\
\text { regulated by } \\
\text { provinces }\end{array}$ & $\begin{array}{l}\text { Government } \\
\text { owns or controls } \\
\text { transportation } \\
\text { and export } \\
\text { facilities }\end{array}$ & & $\begin{array}{l}\text { Regulated by } \\
\text { provinces }\end{array}$ & \\
\hline \multicolumn{9}{|l|}{ TRADE POLICIES } \\
\hline .. import restrictions & & Tariffs only $0.5 \%$ & Tarifts only $1 \%$. & None & None & None & & \\
\hline
\end{tabular}




\begin{tabular}{|c|c|c|c|c|c|c|c|c|}
\hline \multicolumn{9}{|l|}{ Table A.4. (continued) } \\
\hline & & & & & & & & \multirow[b]{3}{*}{$\begin{array}{l}\text { RENEWABLE } \\
\text { ENERGY } \\
\end{array}$} \\
\hline & & \multicolumn{2}{|c|}{ oll- } & & & & & \\
\hline POLICIES & ALL SECTORS & CRUDE & REFINED & MATURAL GAS & CDAL & NUCLEAR & ELECTRICITY & \\
\hline -export restrictions & & Licensed & None & $\begin{array}{l}\text { Regulated but } \\
\text { essentially none } \\
\text { to U.S. }\end{array}$ & None & $\begin{array}{l}\text { Uranium exports } \\
\text { licensed }\end{array}$ & $\begin{array}{l}\text { Reviewed and } \\
\text { Licenced }\end{array}$ & \\
\hline \multicolumn{9}{|l|}{ - export assistance } \\
\hline PRICE CONTROLS & & None & $\begin{array}{l}\text { Prince Edward } \\
\text { Island only }\end{array}$ & None & None & & $\begin{array}{l}\text { Yes-based on } \\
\text { tariffs }\end{array}$ & . \\
\hline \multicolumn{9}{|l|}{ SUBSIDIES } \\
\hline - payments to producers & & On Mega-projects & & On Mega-projects & $\begin{array}{l}\text { Federal Govt. } \\
\text { provides } \\
\text { operating and } \\
\text { capital } \\
\text { expenditures }\end{array}$ & $\begin{array}{l}\text { May be some } \\
\text { servicing of } \\
\text { reactors by } \\
\text { Federal Govt. }\end{array}$ & $\begin{array}{l}\text { Some payments } \\
\text { on transmission } \\
\text { lines }\end{array}$ & \\
\hline - tax incentives & $\begin{array}{l}\text { Accelerated } \\
\text { depreciation on } \\
\text { certain equipment- } \\
\text { energy efficient or } \\
\text { uses renewable } \\
\text { resources }\end{array}$ & $\begin{array}{l}\text { Depletion } \\
\text { allowance } \\
\text { oreater than } \\
\text { actual } \\
\end{array}$ & & & & & & $\begin{array}{l}\text { Accelerated } \\
\text { business } \\
\text { depreciation for } \\
\text { EE items }\end{array}$ \\
\hline -- subsidized energy & & & & & & & Eastern Coal & \\
\hline - low interest rate loans & & Yes & & & & & Yes & \\
\hline $\begin{array}{l}\text { - government-sponsored } \\
\text { research and development }\end{array}$ & $0.05 \%$ of GDP & Small Amount & Small Amount & Small Amount & Small Amount & $\begin{array}{l}67 \% \text { of Govt. } \\
\text { R\&D in } 1992 .\end{array}$ & Small amount & Yes \\
\hline . taxes & $\begin{array}{l}\text { Corporate taxes on } \\
\text { private enterprises }\end{array}$ & $\begin{array}{l}\text { Provincial } \\
\text { Royalties }\end{array}$ & $\begin{array}{l}\text { Consumption } \\
\text { taxes at Federal } \\
\text { and Provincial } \\
\text { Levels , Federal } \\
\text { Excise tax } \\
\end{array}$ & \begin{tabular}{|l} 
Provincial \\
Royalties plus \\
Federal \\
consumption tax
\end{tabular} & $\begin{array}{l}\text { Provincial } \\
\text { Royalties plus } \\
\text { Federal } \\
\text { consumption tax }\end{array}$ & & \begin{tabular}{|l|} 
Federal \\
Consumption Tax
\end{tabular} & \\
\hline
\end{tabular}




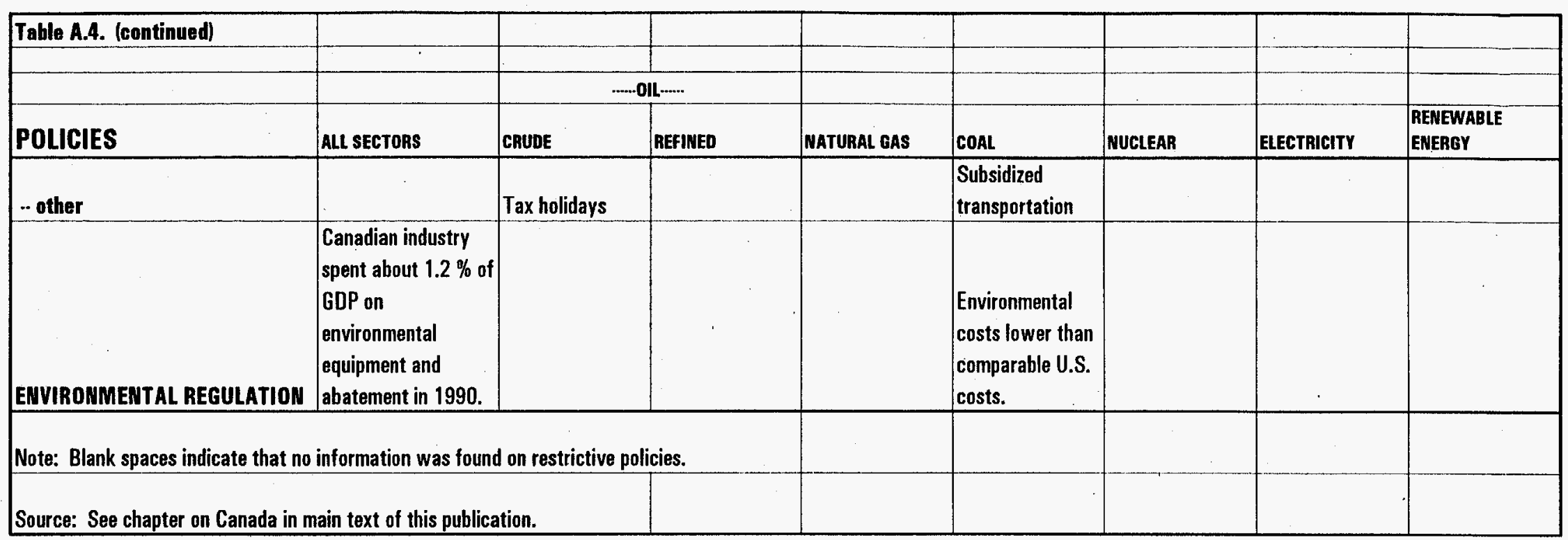




\begin{tabular}{|c|c|c|c|c|c|c|c|c|}
\hline \multicolumn{9}{|c|}{ Table A.5. Summary of Government Policies in Various Energy Sectors of France } \\
\hline & & & & & & & & \\
\hline & \multirow[b]{2}{*}{ ALL SECTORS } & \multicolumn{2}{|c|}{$\ldots \ldots$ oll- } & \multirow[b]{2}{*}{ NATURAL GAS } & \multirow[b]{2}{*}{ COAL } & \multirow[b]{2}{*}{ NUCLEAR } & \multirow[b]{2}{*}{ ELECTRICITY } & \multirow[b]{2}{*}{$\begin{array}{l}\text { RENEWABLE } \\
\text { EMERGY }\end{array}$} \\
\hline POLICIES & & CRUDE & REFINED & & & & & \\
\hline GOVERNMENT OWNERSHIP & $\begin{array}{l}\text { Heavily involved in } \\
\text { energy sector }\end{array}$ & & & & & & & \\
\hline -- natural resources & Government owned & & & & & & & \\
\hline - husiness entitities & & $\begin{array}{l}\text { Partial } \\
\text { government } \\
\text { ownership }\end{array}$ & $\begin{array}{l}\text { Mixed govt. - } \\
\text { private }\end{array}$ & $\begin{array}{l}\text { Government } \\
\text { ownership of } \\
\text { distribution }\end{array}$ & $\begin{array}{l}\text { Government } \\
\text { ownership }\end{array}$ & $\begin{array}{l}\text { Government } \\
\text { ownership }\end{array}$ & $\begin{array}{l}\text { Government } \\
\text { ownership }\end{array}$ & \\
\hline \multicolumn{9}{|l|}{ INVESTMENT POLICIES } \\
\hline -- foreign ownership restrictions & & & & $\begin{array}{l}\text { Distribution } \\
\text { functions } \\
\text { prohibited }\end{array}$ & Prohibited & Prohibited & Prohibited & \\
\hline - production restrictions & & $\begin{array}{l}\text { Govt. licenses } \\
\text { exploration' and } \\
\text { development }\end{array}$ & & $\begin{array}{l}\text { Govt. licenses } \\
\text { exploration and } \\
\text { development }\end{array}$ & & & & \\
\hline .. distribution restrictions & & & $\begin{array}{l}\text { French refineries } \\
\text { must use French } \\
\text { flag tankers }\end{array}$ & GdF monopoly & & & $\begin{array}{l}\text { Monopoly by } \\
\text { EdF, no third } \\
\text { party access }\end{array}$ & \\
\hline \multicolumn{9}{|l|}{ TRADE POLICIES } \\
\hline .- import restrictions & & & $\begin{array}{l}\text { EC tariff code } \\
\text { applies }\end{array}$ & GdF monopoly & Highly controlled & & EdF monopoly & \\
\hline . export restrictions & & & & GdF monopoly & & & & \\
\hline \multicolumn{9}{|l|}{ - export assistance } \\
\hline PRICE CONTROLS & & & & $\begin{array}{l}\text { Consumer prices } \\
\text { regulated, large } \\
\text { customers are } \\
\text { not }\end{array}$ & \begin{tabular}{|l} 
Based on \\
international \\
market prices
\end{tabular} & & Regulated & \\
\hline
\end{tabular}




\begin{tabular}{|c|c|c|c|c|c|c|c|c|}
\hline \multicolumn{9}{|l|}{ Table A.5. (continued) } \\
\hline & & & & & & & & \\
\hline & & \multicolumn{2}{|c|}{$\ldots .011 \ldots$} & \multirow[b]{2}{*}{ NATURAL GAS } & \multirow[b]{2}{*}{ COAL } & \multirow[b]{2}{*}{ NUCLEAR } & \multirow[b]{2}{*}{ ELECTRICITY } & \multirow[b]{2}{*}{$\begin{array}{l}\text { RENEWABLE } \\
\text { ENERGY }\end{array}$} \\
\hline POLICIES & ALL SECTORS & CRUDE & REFINED & & & & & \\
\hline \multicolumn{9}{|l|}{ SUBSIDIES } \\
\hline .- payments to producers & & & & & $\begin{array}{l}\text { Substantial - } \\
\text { Costs } \$ 70 \text { I } \\
\text { tonne, intl price } \\
\$ 40 / \text { tonne }\end{array}$ & & & \\
\hline .. tax incentives & & $\begin{array}{l}\text { Tax deferrals for } \\
\text { exploration and } \\
\text { possible } \\
\text { exemption. }\end{array}$ & & $\begin{array}{l}\text { Tax deferrals for } \\
\text { exploration and } \\
\text { possible } \\
\text { exemption. }\end{array}$ & & & $\begin{array}{l}\text { No excise tax for } \\
\text { cogeneration } \\
\text { with natural gas }\end{array}$ & \\
\hline \multicolumn{9}{|l|}{.. subsidized energy } \\
\hline \multicolumn{9}{|l|}{ - low interest rate loans } \\
\hline $\begin{array}{l}\text { - government-sponsored } \\
\text { research and development }\end{array}$ & $\begin{array}{l}0.049 \text { percent of } \\
\text { GDP, } 88 \% \text { on } \\
\text { nuclear }\end{array}$ & $\begin{array}{l}\text { With gas, about } 6 \\
\% \text { of Govt. R\&D } \\
\text { spending }\end{array}$ & & $\begin{array}{l}\text { With oil, about } 6 \\
\% \text { of Govt. R\&D } \\
\text { spending }\end{array}$ & Some & $\begin{array}{l}88 \% \text { of govt. } \\
\text { spending }\end{array}$ & Some & Some \\
\hline - taxes and regulations & Emission taxes & $\begin{array}{l}\text { Government } \\
\text { royalties as high } \\
\text { as } 12 \% \text {, plus } \\
\text { corporate taxes } \\
\text { of } 34 \% \\
\end{array}$ & $\begin{array}{l}18.6 \% \text { VAT, } \\
\text { Excise taxes, } \\
\text { others }\end{array}$ & $\begin{array}{l}\text { Production - } 5 \% \\
\text { royalty, } \\
\text { Consumption - } \\
18.6 \% \text { VAT }\end{array}$ & VAT $-18.6 \%$ & & $18.6 \%$ VAT & \\
\hline \multicolumn{9}{|l|}{.. other } \\
\hline $\begin{array}{l}\text { ENVIRONMENTAL } \\
\text { REGULATIONS } \\
\end{array}$ & $\begin{array}{l}\text { The French spent } \\
\text { about .84 \% of GDP } \\
\text { on environmental } \\
\text { equipment and } \\
\text { abatement. }\end{array}$ & & & & & & . & \\
\hline Note: Blank spaces indicate th & information was found & I on restrictive polic & & & & & & \\
\hline Source: See chapter on Franc & in text of publication. & & & & & & & \\
\hline
\end{tabular}




\begin{tabular}{|c|c|c|c|c|c|c|c|c|}
\hline \multicolumn{9}{|c|}{ Table A.6. Government Policies in Various Energy Sectors of Mexico } \\
\hline & & \multicolumn{2}{|c|}{......oll } & & & & & \\
\hline POLICIES & ALL SECTORS & CRUDE & REFINED & NATURAL GAS & COAL & NUCLEAR & ELECTRICITY & $\begin{array}{l}\text { RENEWABLE } \\
\text { ENERGY }\end{array}$ \\
\hline \multicolumn{9}{|l|}{ GOVERNMENT OWNERSHIP } \\
\hline -n natural resources & & $\begin{array}{l}\text { Constitionally } \\
\text { owns } \\
\text { hydrocarbon }\end{array}$ & $\begin{array}{l}\text { Constitionally } \\
\text { owns } \\
\text { hrdrocarbon }\end{array}$ & $\begin{array}{l}\text { Constitionally } \\
\text { owns } \\
\text { hydrocarbon }\end{array}$ & & & & \\
\hline -- business entitities & & Parastatal & Parastatal & Parastatal & Private & $\begin{array}{l}\text { Government } \\
\text { owned and } \\
\text { controlled }\end{array}$ & Parastatal & \\
\hline -- further information & $\begin{array}{l}\text { PEMEX and CFE } \\
\text { control the energy } \\
\text { sector }\end{array}$ & & & & & & & \\
\hline \multicolumn{9}{|l|}{ INVESTMENT POLICIES } \\
\hline .. foreign ownership restrictions & & $\begin{array}{l}\text { Constitutionally } \\
\text { precluded }\end{array}$ & $\begin{array}{l}\text { Constitutionally } \\
\text { precluded }\end{array}$ & $\begin{array}{l}\text { Constitutionally } \\
\text { precluded }\end{array}$ & $\begin{array}{l}\text { None on new } \\
\text { mines, some on } \\
\text { existing. }\end{array}$ & & $\begin{array}{l}\text { Constitutionally } \\
\text { precluded }\end{array}$ & \\
\hline \multicolumn{9}{|l|}{.. production restrictions } \\
\hline - distribution restrictions & & $\begin{array}{l}\text { Monopoly control } \\
\text { by PEMEX }\end{array}$ & $\begin{array}{l}\text { Monopoly control } \\
\text { by PEMEX }\end{array}$ & $\begin{array}{l}\text { Monopoly control } \\
\text { by PEMEX }\end{array}$ & & & & \\
\hline TRADE POLICIES & . & $\begin{array}{l}\text { Import taritts on } \\
\text { U.S. and Can. } \\
\text { phased out over } \\
10 \text { years }\end{array}$ & $\begin{array}{l}\text { Import tariffs on } \\
\text { U.S. and Can. } \\
\text { phased out over } \\
10 \text { years } \\
\end{array}$ & $\begin{array}{l}\text { Import tariffs on } \\
\text { U.S. and Can. } \\
\text { phased out over } \\
10 \text { years }\end{array}$ & & & $\begin{array}{l}\text { Import tariffs on } \\
\text { U.S. and Canada } \\
\text { phased out over } \\
5 \text { years }\end{array}$ & \\
\hline -. import restrictions & & $\begin{array}{l}\text { Monopoly control } \\
\text { by PEMEX }\end{array}$ & $\begin{array}{l}\text { Monopoly control } \\
\text { by PEMEX }\end{array}$ & $\begin{array}{l}\text { Monopoly control } \\
\text { by PEMEX }\end{array}$ & & & $\begin{array}{l}\text { CFE monopoly } \\
\text { buyer }\end{array}$ & \\
\hline
\end{tabular}




\begin{tabular}{|c|c|c|c|c|c|c|c|c|}
\hline \multicolumn{9}{|l|}{ Table A.6. (continued) } \\
\hline & & & & & & & & \\
\hline & & \multicolumn{2}{|c|}{$\ldots . . .011 \ldots . . . .}$. & & & & & \\
\hline POLICIES & ALL SECTORS & CRUOE & BEFINED & NATURAL GAS & COAL & MUCLEAR & ELECTRICTY & $\begin{array}{l}\text { RENEWABLE } \\
\text { ENERGY } \\
\end{array}$ \\
\hline - export restrictions & & $\begin{array}{l}\text { Monopoly control } \\
\text { by PEMEX }\end{array}$ & $\begin{array}{l}\text { Monopoly control } \\
\text { by PEMEX }\end{array}$ & $\begin{array}{l}\text { Monopoly control } \\
\text { by PEMEX }\end{array}$ & & & $\begin{array}{l}\text { NAFTA allows } \\
\text { U.S. and } \\
\text { Canadian } \\
\text { investors to } \\
\text { export electricity } \\
\text { over CFE lines }\end{array}$ & \\
\hline - oxport assistance & Some & & & & & & & \\
\hline PRICE CONTROLS & & \begin{tabular}{|l|} 
Prices and taxes \\
domestic and \\
imported \\
products \\
differentially
\end{tabular} & $\begin{array}{l}\text { Prices and taxes } \\
\text { domestic and } \\
\text { imported } \\
\text { products } \\
\text { differentially }\end{array}$ & $\begin{array}{l}\text { Prices and taxes } \\
\text { domestic and } \\
\text { imported } \\
\text { products } \\
\text { differentially }\end{array}$ & & & $\begin{array}{l}\text { Prices and taxes } \\
\text { domestic and } \\
\text { imported } \\
\text { products } \\
\text { differentially }\end{array}$ & \\
\hline SUBSIDIES & & & & & & & & \\
\hline -. payments to producers & & & & & & & Subsidized sector & \\
\hline$\cdots$ tax incentives & & & & & & & & \\
\hline .- subsidized energy & & & & & & & & \\
\hline - low interest rate loans & & & & & & & & \\
\hline $\begin{array}{l}\text { - government-sponsored } \\
\text { research and development }\end{array}$ & $\begin{array}{l}\text { Some regulations } \\
\text { intended to } \\
\text { encourage R\&D. } \\
\text { Provides funds to } \\
\text { NAFIN and } \\
\text { CONACYT for R\&D. }\end{array}$ & & ' & & & & & ? \\
\hline
\end{tabular}




\begin{tabular}{|c|c|c|c|c|c|c|c|c|}
\hline \multicolumn{9}{|l|}{ Table A.6. (continued) } \\
\hline & & & & & & & & \\
\hline & & \multicolumn{2}{|c|}{$\ldots \ldots . .011 \ldots . . . .}$. & & & & & \\
\hline POLICIES & ALL SECTORS & CRUDE & REFINED & NATURAL GAS & COAL & NUCLEAR & ELECTRICTY & $\begin{array}{l}\text { RENEWABLLE } \\
\text { ENERGY }\end{array}$ \\
\hline - taxes and regulations & $\begin{array}{l}\text { Corporate taxes } \\
\text { excopt on electricity } \\
\text { of } 34 \% \text {. }\end{array}$ & $\begin{array}{l}\text { Production taxed } \\
\text { by productivity of } \\
\text { site }\end{array}$ & $\begin{array}{l}\text { Taxes on retail } \\
\text { sales to offset } \\
\text { crude oil price } \\
\text { fluctuations }\end{array}$ & $\begin{array}{l}\begin{array}{l}\text { Production taxed } \\
\text { by productivity of } \\
\text { site }\end{array} \\
\end{array}$ & & & & \\
\hline \multicolumn{9}{|l|}{$\approx$ other } \\
\hline ENVIRONMENTAL REGULATION & $\begin{array}{l}\text { In } 1990, \text { Mexico was } \\
\text { at about } 30 \% \text { of } \\
\text { U.S. implementation. }\end{array}$ & & & & & & & \\
\hline \multicolumn{9}{|c|}{ Note: Blank spaces indicate that no information was found on restrictive policies. } \\
\hline Source: Sea chapter on Mexico in & ain text of this publicat & tion. & & & & & & \\
\hline
\end{tabular}




\begin{tabular}{|c|c|c|c|c|c|c|c|c|}
\hline \multicolumn{9}{|c|}{ Table A.7. Government policies in various energy sectors of the Netherlands } \\
\hline & & \multirow{2}{*}{\multicolumn{2}{|c|}{.....0ll_...... }} & \multirow[b]{3}{*}{ NATURAL GAS } & & & & \\
\hline & & & & & \multirow[b]{2}{*}{ COAL } & \multirow[b]{2}{*}{ NUCLEAR } & \multirow[b]{2}{*}{ ELECTAICITY } & \multirow[b]{2}{*}{$\begin{array}{l}\text { RENEWABLE } \\
\text { ENERGY }\end{array}$} \\
\hline POLICIES & ALL SECTOAS & CRUDE & BEFINED & & & & & \\
\hline \multicolumn{9}{|l|}{ GOVERNMENT OWNERSHIP } \\
\hline -n natural resources & & Govt. owned & & Govt. owned & & & & \\
\hline - business entitities & & \begin{tabular}{|l} 
Private \\
exploration.
\end{tabular} & Private. & $\begin{array}{l}\text { Upstream } \\
\text { private, } \\
\text { downstream-- } \\
\text { mixed private and } \\
\text { govt. }\end{array}$ & $\begin{array}{l}\text { No coal mining in } \\
\text { the Netherlands. }\end{array}$ & $\begin{array}{l}\text { Municipally and } \\
\text { Provincially } \\
\text { owned }\end{array}$ & $\begin{array}{l}\text { Production and } \\
\text { distribution } \\
\text { companies are } \\
\text { provincially and } \\
\text { municipally } \\
\text { owned. } \\
\text { Generation can } \\
\text { be private. }\end{array}$ & Private \\
\hline \multicolumn{9}{|l|}{ INVESTMENT POLICIES } \\
\hline .. foreign ownership restrictions & & & & & & & $\begin{array}{l}\text { No legal } \\
\text { restrictions, but } \\
\text { no foreign } \\
\text { ownership } \\
\end{array}$ & \\
\hline - production restrictions & & & & $\begin{array}{l}\text { No new licenses } \\
\text { will be issued } \\
\text { until 1995. }\end{array}$ & & Must be licensed & $\begin{array}{l}\text { Voluntary limits } \\
\text { on emissions }\end{array}$ & \\
\hline .. distribution restrictions & & & & $\begin{array}{l}\text { Gasunie is } \\
\text { monopoly owner } \\
\text { of the gas } \\
\text { pipelines. }\end{array}$ & & & $\begin{array}{l}\text { SEP has } \\
\text { monopoly. }\end{array}$ & \\
\hline \multicolumn{9}{|l|}{ TRADE POLICIES } \\
\hline -- import restrictions & & & & $\begin{array}{l}\text { Gasunie only } \\
\text { importer }\end{array}$ & & & $\begin{array}{l}\text { Only SEP and } \\
\text { consumers may } \\
\text { import. }\end{array}$ & \\
\hline .. export restrictions & & . & & $\begin{array}{l}\text { Govt. approval } \\
\text { required. }\end{array}$ & & & No controls & \\
\hline - export assistance & & & & & & & & \\
\hline
\end{tabular}




\begin{tabular}{|c|c|c|c|c|c|c|c|c|}
\hline Table A.7. (continued) & & & & & & & & \\
\hline & & & & & & & & \\
\hline & & \multicolumn{2}{|c|}{$\ldots . .011 \ldots . . .}$. & & & & & \\
\hline POLICIES & ALL SECTORS & CAUDE & REFINED & NaTURAL gas & COAL & NUCLEAR & ELECTRICITY & $\begin{array}{l}\text { RENEWABIE } \\
\text { ENERGY }\end{array}$ \\
\hline PRICE CONTROLS & & & & \begin{tabular}{|l|} 
Monopoly priced \\
at cost + \\
transportation + \\
markup.
\end{tabular} & & & $\begin{array}{l}\text { SEP sets rate; } \\
\text { distribution } \\
\text { companies } \\
\text { regulated. }\end{array}$ & \\
\hline \multicolumn{9}{|l|}{ SUBSIDIES } \\
\hline - payments to producers & & & & & & & \begin{tabular}{|l|} 
Cogeneration \\
receives 25 \\
percent grant
\end{tabular} & $\begin{array}{l}\text { Wind and solar } \\
\text { energy }\end{array}$ \\
\hline \multicolumn{9}{|l|}{- tax incentives } \\
\hline \multicolumn{9}{|l|}{.- subsidized energy } \\
\hline \multicolumn{9}{|l|}{ - low interest rate loans } \\
\hline $\begin{array}{l}\text { - government-sponsored } \\
\text { research and development }\end{array}$ & $\begin{array}{l}\text { Govt. energy R\&D } \\
\text { spending } 0.057 \% \text { of } \\
\text { GDP in } 1992\end{array}$ & & & & & & & $\begin{array}{l}\text { Alternative fuels, } \\
\text { energy } \\
\text { conservation and } \\
\text { environmental } \\
\text { protection. }\end{array}$ \\
\hline - taxes and regulations & & \begin{tabular}{|l|} 
Royalties up to \\
$16 \%$ of wellhead \\
value, and $50 \%$ \\
State Profit \\
Share and \\
Corporate Income \\
Taxes or $50 \%$ of \\
Revenues. \\
\end{tabular} & $\begin{array}{l}17.5 \% \text { VAT on } \\
\text { oil products. }\end{array}$ & \begin{tabular}{|l|} 
Royalties up to \\
$16 \%$ of wellhead \\
value, and $50 \%$ \\
State Profit \\
Share and \\
Corporate Income \\
Taxes or $50 \%$ of \\
Revenues. \\
Consumers pay \\
$17.5 \%$ VAT. \\
\end{tabular} & $\begin{array}{l} \\
\text { Environmental } \\
\text { tax of } 22.64 \text { Gld } \\
\text { per metric ton. }\end{array}$ & & $17.5 \%$ VAT & \\
\hline .. other & & & & & & & & \\
\hline
\end{tabular}




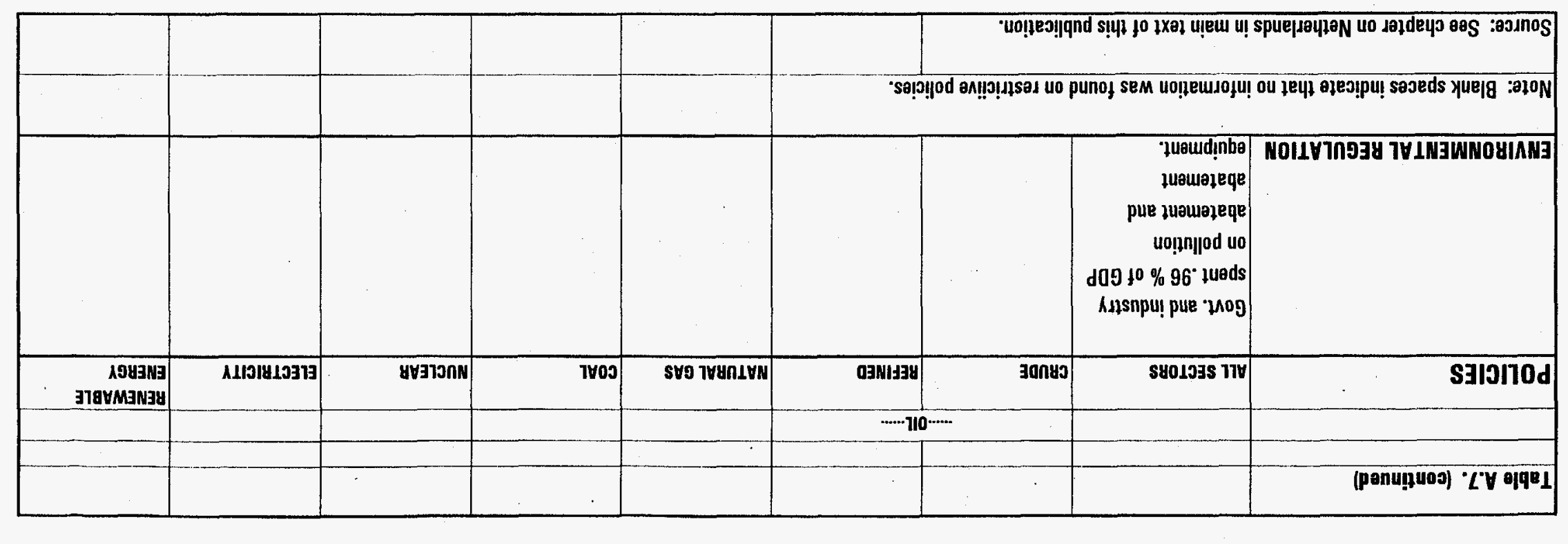




\begin{tabular}{|c|c|c|c|c|c|c|c|c|}
\hline \multicolumn{9}{|c|}{ Table A.8. Government Policies in Various Energy Seetors of Norway } \\
\hline & & \multirow{2}{*}{\multicolumn{2}{|c|}{$\ldots . . . .011 \ldots . . . .}}$. & & & & & \multirow[b]{3}{*}{$\begin{array}{l}\text { RENEWABLL } \\
\text { ENERGY } \\
\end{array}$} \\
\hline & & & & & & \multirow[b]{2}{*}{ NUCLEAR } & \multirow[b]{2}{*}{ ELECTRICITY } & \\
\hline POLICIES & ALL SECTORS & CRUDE & REFINED . & NATURAL GAS & COAL & & & \\
\hline \multicolumn{9}{|l|}{ GOVERNMENT OWNERSHIP } \\
\hline - natural resources & Govt. owned & & & & & & & \\
\hline -- business entitities & & $\begin{array}{l}\text { Mixed govt.- } \\
\text { private }\end{array}$ & $\begin{array}{l}\text { Mixed govt.- } \\
\text { private }\end{array}$ & $\begin{array}{l}\text { Mixed govt. } \\
\text { private }\end{array}$ & Govt. owned & & $\begin{array}{l}\text { Mixed Govt.- } \\
\text { private. }\end{array}$ & \\
\hline \multicolumn{9}{|l|}{ INVESTMENT POLICIES } \\
\hline - foreign ownership restrictions & & $\begin{array}{l}\text { All investment - } \\
\text { a joint venture. }\end{array}$ & & & & & & \\
\hline ..p production restrictions & & \begin{tabular}{|l} 
Government \\
holds share in all \\
new licenses. \\
Production plans \\
are approved by \\
Norwegian govt. \\
\end{tabular} & & \begin{tabular}{|l} 
Semi-coordinated \\
by a consortium \\
led by Statoil \\
\end{tabular} & & & $\begin{array}{l}\text { Statkraft } \\
\text { produces about } \\
\text { one third of } \\
\text { electricity. } \\
\text { Supply is } \\
\text { competitive. } \\
\text { Govt licenses } \\
\text { waterfalls. } \\
\end{array}$ & \\
\hline .. distribution restrictions & & $\begin{array}{l}\text { Pipelines require } \\
\text { licensing. }\end{array}$ & & & & & $\begin{array}{l}\text { Stattnet owns 85 } \\
\text { percent of } \\
\text { transmission } \\
\text { capacity. }\end{array}$ & . \\
\hline \multicolumn{9}{|l|}{ TRADE POLICIES } \\
\hline -. import restrictions & & & & No imports. & & & $\begin{array}{l}\text { Controlled by } \\
\text { Statkraft }\end{array}$ & \\
\hline .. export restrictions & & $\begin{array}{l}\text { None if within } \\
\text { production plan. }\end{array}$ & & $\begin{array}{l}\text { None if within } \\
\text { production plan. }\end{array}$ & & & $\begin{array}{l}\text { Controlled by } \\
\text { Statkraft }\end{array}$ & \\
\hline \multicolumn{9}{|l|}{--export assistance } \\
\hline PRICE CONTROLS & & & $\begin{array}{l}\text { Reviewed by } \\
\text { Govt. }\end{array}$ & $\begin{array}{l}\text { Negotiated by } \\
\text { consortium. }\end{array}$ & & & Regulated & \\
\hline
\end{tabular}




\begin{tabular}{|c|c|c|c|c|c|c|c|c|}
\hline \multicolumn{9}{|l|}{ Table A.8. (continued) } \\
\hline & & & & & & & & \\
\hline & & \multicolumn{2}{|c|}{$-011-\ldots$} & & & & & \\
\hline POLICIES & ALL SECTORS & CRUDE & AEFINED & NATURAL GAS & COAL & NUCLEAR & ELECTRICITY & $\begin{array}{l}\text { RENEWABLE } \\
\text { ENERGY } \\
\end{array}$ \\
\hline \multicolumn{9}{|l|}{ SUBSIDIES } \\
\hline - payments to producers & & $\begin{array}{l}\text { Govt. funds a } \\
\text { portion of } \\
\text { exploration and } \\
\text { development } \\
\text { activities. }\end{array}$ & & $\begin{array}{l}\text { Govt. funds a } \\
\text { portion of } \\
\text { exploration and } \\
\text { development } \\
\text { activities. }\end{array}$ & $\begin{array}{l}\text { Heavily } \\
\text { subsidized }\end{array}$ & & & \\
\hline - tax incentives & $\begin{array}{l}\text { R\&D expenditures } \\
\text { can be immediately } \\
\text { expensed. }\end{array}$ & & & & & & & \\
\hline \multicolumn{9}{|l|}{.. subsidized energy } \\
\hline \multicolumn{9}{|l|}{ - low interest rate leans } \\
\hline $\begin{array}{l}\text { - government-sponsored } \\
\text { research and development }\end{array}$ & $\begin{array}{l}\text { The Govt. spent } \\
0.056 \text { percent of } \\
\text { GDP in } 1992 \text { or } \\
\text { about } \$ 63 \text { million }\end{array}$ & $\begin{array}{l}\$ 17 \text { million on oil } \\
\text { and gas } R \& D\end{array}$ & & $\begin{array}{l}\$ 17 \text { million on oil } \\
\text { and gas } R \& D\end{array}$ & & & $\begin{array}{l}\text { Approximately } \\
\$ 37 \text { million } \\
\text { spent. }\end{array}$ & \\
\hline - taxes and regulations & $\begin{array}{l}\text { Corporate tax rates } \\
\text { are } 28 \text { percent and } \\
\text { appropriate state } \\
\text { and municipal taxes. }\end{array}$ & $\begin{array}{l}50 \text { percent } \\
\text { special tax, } \\
\text { royalties on old } \\
\text { fields, } 50 \text { percent } \\
\text { of wellhead } \\
\text { revenues for } \\
\text { government } \\
\text { share, } \\
\end{array}$ & $20 \%$ VAT & $\begin{array}{l}50 \text { percent } \\
\text { special tax, } \\
\text { royalties on old } \\
\text { fields, } 50 \text { percent } \\
\text { of wellhead } \\
\text { revenues for } \\
\text { government } \\
\text { share. }\end{array}$ & & & $20 \%$ VAT & \\
\hline - other & & ' & & & & & $\begin{array}{l}\text { Govt allowing } \\
\text { Statkraft to } \\
\text { collect fees } \\
\text { higher than } \\
\text { costs. } \\
\end{array}$ & \\
\hline
\end{tabular}




\begin{tabular}{|c|c|c|c|c|c|c|c|c|}
\hline \multicolumn{9}{|c|}{ Table A.8. (continued) } \\
\hline & & & $\cdot$ & & & & & \\
\hline & & \multicolumn{2}{|c|}{$\ldots . . .011-\ldots . . .}$. & & & & & \\
\hline POLICIES & ALL SECTORS & CRUDE & REFINED & MATURAL GAS & COAL & NUCLEAR & ELECTRICITY & $\begin{array}{l}\text { RENEWABLE } \\
\text { ENERGY }\end{array}$ \\
\hline $\begin{array}{l}\text { ENVIRONMENTAL } \\
\text { REGULATIONS }\end{array}$ & $\begin{array}{l}\text { Govt. and private } \\
\text { industry spent about } \\
.66 \% \text { of GDP on } \\
\text { environmental } \\
\text { equipment and } \\
\text { abatement. }\end{array}$ & $\begin{array}{l}\text { Environmental } \\
\text { tax }\end{array}$ & $\begin{array}{l}\text { Emission taxes - } \\
\text { gasoline, } \$ 196 \\
\text { per metric ton of } \\
\text { carbon; fuel oil, } \\
\$ 66 \text { per metric } \\
\text { ton of carbon. }\end{array}$ & & $\begin{array}{l}\text { Environmental } \\
\text { tax of } \$ 47-70 \text { per } \\
\text { metric ton of } \\
\text { carbon }\end{array}$ & & & . \\
\hline lote: Blank spaces i & . & n restrictiv & & & & & & \\
\hline
\end{tabular}




\begin{tabular}{|c|c|c|c|c|c|c|c|c|}
\hline \multicolumn{9}{|c|}{ Table A.9. Government Policies in Various Energy Sectors of the United Kingdom } \\
\hline & & \multirow{2}{*}{\multicolumn{2}{|c|}{$\ldots \ldots$ oll }} & & & & & \multirow[b]{3}{*}{\begin{tabular}{|l|} 
RENEWABLLE \\
ENERGY
\end{tabular}} \\
\hline & & & & & & & & \\
\hline POLICIES & ALL SECTORS & CRUDE & REFINED & NATURAL GAS & COAL & NUCLEAR & ELECTRICITY & \\
\hline \multicolumn{9}{|l|}{ GOVERHMENT OWNERSHIP } \\
\hline -n natural resources & Owned by the Crown & & & & & & & \\
\hline - business entitities & & Private & Private & Private & $\begin{array}{l}100 \% \text { govt. } \\
\text { owned }\end{array}$ & $\begin{array}{l}100 \% \text { govt. } \\
\text { owned }\end{array}$ & $\begin{array}{l}\text { Mostly private, } \\
\text { some govt. } \\
\text { ownership }\end{array}$ & \\
\hline \multicolumn{9}{|l|}{ INVESTMENT POLICIES } \\
\hline -. foreign ownership restrictions & & $\begin{array}{l}\text { Licenses all } \\
\text { production and } \\
\text { sometimes limits } \\
\text { foreign } \\
\text { ownership. }\end{array}$ & $\begin{array}{l}\text { Can be } \\
\text { investment limits }\end{array}$ & $\begin{array}{l}\text { Licenses all } \\
\text { production and } \\
\text { sometimes limits } \\
\text { foreign } \\
\text { ownership. } \\
\end{array}$ & $\begin{array}{l}\text { Prevented by } \\
\text { British Coal } \\
\text { monopoly. } \\
\end{array}$ & $\begin{array}{l}\text { Government } \\
\text { monopoly. }\end{array}$ & \begin{tabular}{|l|}
$\begin{array}{l}\text { Can be } \\
\text { investment limits }\end{array}$ \\
\end{tabular} & \\
\hline - production restrictions & & $\begin{array}{l}\text { Licenses more } \\
\text { than a formality. }\end{array}$ & $\begin{array}{l}\text { There may be } \\
\text { investment limits }\end{array}$ & $\begin{array}{l}\text { Licenses more } \\
\text { than a formality. }\end{array}$ & $\begin{array}{l}\text { Until } 1995 \\
\text { British Coal has } \\
\text { guaranteed } \\
\text { markets. }\end{array}$ & & $\begin{array}{l}\text { Siting must be } \\
\text { licensed. }\end{array}$ & $\begin{array}{l}\text { Licensing exempt } \\
\text { if more than } 51 \\
\% \text { of CHP energy } \\
\text { used internally. }\end{array}$ \\
\hline - distribution restrictions & & $\begin{array}{l}\text { All oil produced } \\
\text { on the outer } \\
\text { continental shelf } \\
\text { must be landed in } \\
\text { Britain }\end{array}$ & $\begin{array}{l}\text { Pipelines require } \\
\text { govt. approval }\end{array}$ & \begin{tabular}{|l|} 
Pipelines require \\
govt. approval. \\
Most pipeline \\
owned by Br. \\
Gas but open to \\
third parties. \\
\end{tabular} & & & $\begin{array}{l}\text { Required to } \\
\text { contract } 20 \% \text { of } \\
\text { power generation } \\
\text { from nonfossil } \\
\text { fuels }\end{array}$ & 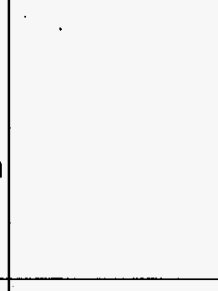 \\
\hline \multicolumn{9}{|l|}{ TRADE POLICIES } \\
\hline - import restrictions & & $\begin{array}{l}\text { No tariffs or } \\
\text { restrictions. }\end{array}$ & EC tariff rates & No tariffs. & $\begin{array}{l}\text { Imports will be } \\
\text { free in } 1995\end{array}$ & & None. & \\
\hline
\end{tabular}




\begin{tabular}{|c|c|c|c|c|c|c|c|c|}
\hline \multicolumn{9}{|l|}{ Table A.9. (continued) } \\
\hline & & \multicolumn{2}{|c|}{$-0011 . .}$. & \multirow[b]{2}{*}{ MATURAL gas } & \multirow[b]{2}{*}{ COAL } & \multirow[b]{2}{*}{ MUCLEAR } & \multirow[b]{2}{*}{ ELECTRICITY } & \multirow[b]{2}{*}{$\begin{array}{l}\text { RENEWABLE } \\
\text { ENERGY }\end{array}$} \\
\hline POLICIES & All SECTORS & CRUDE & REFINED & & & & & \\
\hline -- export restrietions & & None & None & \begin{tabular}{|l|} 
All gas must be \\
landed, export \\
approval \\
required, \\
exceptions for \\
EC. \\
\end{tabular} & None. & \begin{tabular}{|l|} 
All trade in \\
nuclear materials \\
is subject to \\
licensing
\end{tabular} & None. & \\
\hline \multicolumn{9}{|l|}{.. export assistance } \\
\hline PRICE CONTROLS & & & & $\begin{array}{l}\text { No wellhead } \\
\text { controls, } \\
\text { residential tariff } \\
\text { schedules } \\
\text { approved }\end{array}$ & & & $\begin{array}{l}\text { Residential is } \\
\text { regulated, } \\
\text { commercial is } \\
\text { competitive. }\end{array}$ & \\
\hline \multicolumn{9}{|l|}{ SUBSIDIES } \\
\hline payments to producers & & & & & $\begin{array}{l}\text { grants to British } \\
\text { Coal to cover } \\
\text { operating and } \\
\text { capital costs. }\end{array}$ & & & \\
\hline \multicolumn{9}{|l|}{ - tax incentives } \\
\hline .. subsidized energy & & & & & $\begin{array}{l}\text { Subsidies for } \\
\text { purchase of } \\
\text { domestic coal. }\end{array}$ & & $\begin{array}{l}\text { Subsidies for } \\
\text { purchase of } \\
\text { domestic coal }\end{array}$ & \\
\hline - low interest rate loans & & & & & Yes. & & & \\
\hline $\begin{array}{l}\text { - government-sponsored } \\
\text { research and development }\end{array}$ & $0.022 \%$ of GOP & $\begin{array}{l}\text { Gas and oil } \\
\text { account for 6\% } \\
\text { of Govt spending } \\
\text { on R\&D }\end{array}$ & & $\begin{array}{l}\text { Gas and oil } \\
\text { account for 6\% } \\
\text { of Govt spending } \\
\text { on R\&D }\end{array}$ & $\begin{array}{l}\text { About } 3 \% \text { of } \\
\text { govt. R\&D } \\
\text { spending. }\end{array}$ & $\begin{array}{l}70 \% \text { of Govt } \\
\text { R\&D spending. }\end{array}$ & & $\begin{array}{l}10 \% \text { of govt } \\
\text { spending. }\end{array}$ \\
\hline
\end{tabular}




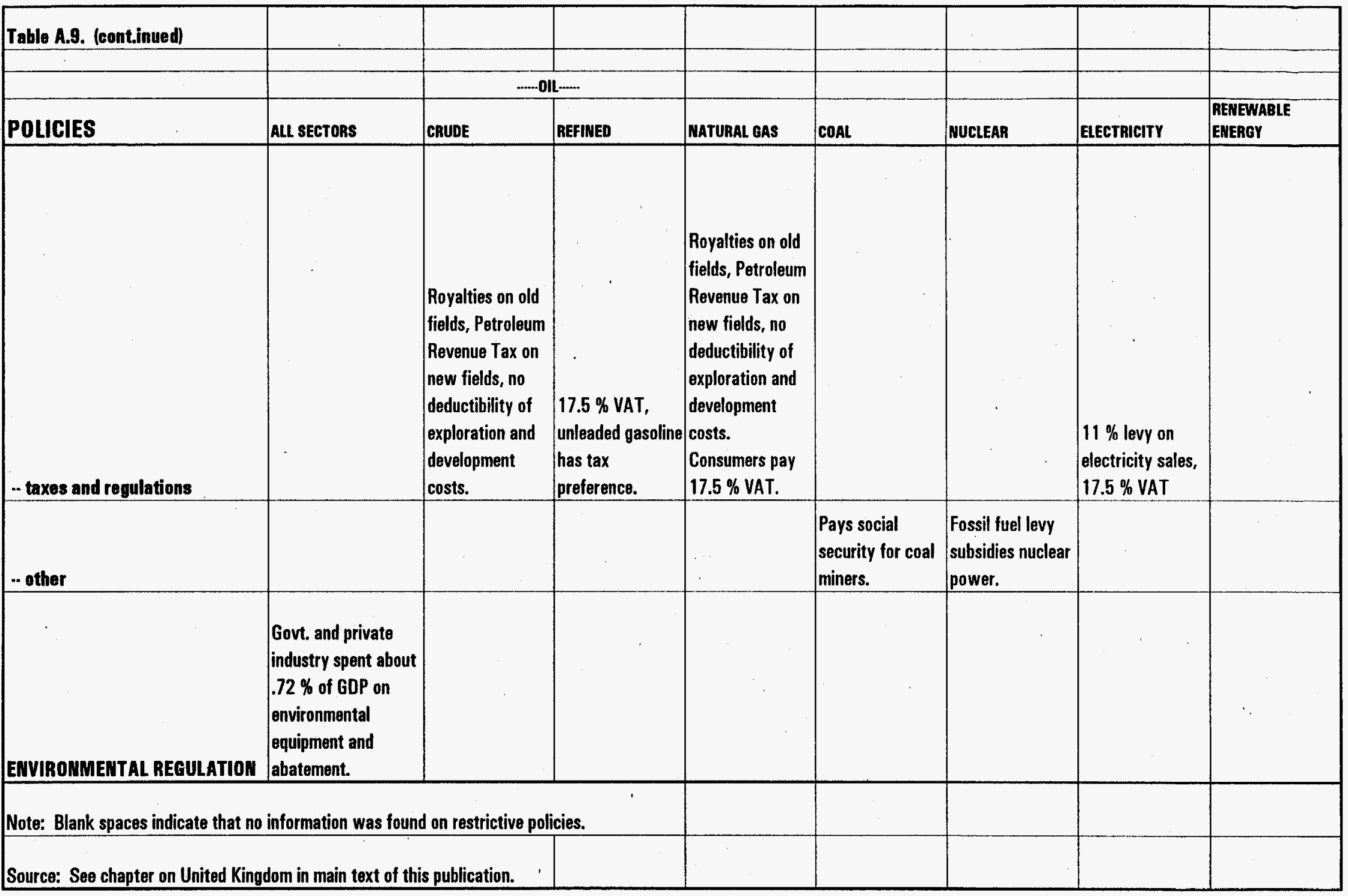




\section{Distribution}

No. of

Copies

OFFSITE

12 DOE/Office of Scientific and Technical Information

20 M. G. Ortmeier

Office of Energy Intelligence

U.S. Department of Energy

MS NN-32

1000 Independence Avenue, SW

Washington, DC 20585

M. Crandall

Industrial College of

Armed Forces

Fort Lesley Fort McNair

Washington, DC 20319

M. B. Davis

Office of Energy Intelligence

U.S. Department of Energy

MS NN-32

1000 Independence Avenue, SW

Washington, DC 20585
No. of

Copies

J. J. Dooly

Battelle Washington Operations

901 D St. SW STE 900

Washington, DC 20024

DOE Richland Operations Office

R. B. Goranson

\section{ONSITE}

\section{Pacific Northwest Laboratory}

L. M. Martucci

(K6-48)

B. R. Shaw

(K6-88)

D. L. Shankle

(K8-11)

D. R. Dixon

(K8-17)

J. M. Roop (5)

(K8-17)

K. A. Freund (5)

(K8-11)

M. R. Weimar (15)

(K8-17)

Publishing Coordination

Distr.1 